ESCOLA POLITÉCNICA DA UNIVERSIDADE DE SÃO PAULO

RICARDO LUIS GEDRA

\title{
ANÁLISE DE VIABILIDADE FINANCEIRA PARA OBTENÇÃO DE CRÉDITOS DE CARBONO EM PROJETOS DE EFICIÊNCIA ENERGÉTICA
}


RICARDO LUIS GEDRA

\section{ANÁLISE DE VIABILIDADE FINANCEIRA PARA OBTENÇÃO DE CRÉDITOS DE CARBONO EM PROJETOS DE EFICIÊNCIA ENERGÉTICA}

Dissertação apresentada à Escola Politécnica da Universidade de São Paulo para obtenção do título de Mestre em Engenharia Elétrica 
RICARDO LUIS GEDRA

\title{
ANÁLISE DE VIABILIDADE FINANCEIRA PARA OBTENÇÃO DE CRÉDITOS DE CARBONO EM PROJETOS DE EFICIÊNCIA ENERGÉTICA
}

\author{
Dissertação apresentada à Escola \\ Politécnica da Universidade de São Paulo \\ para obtenção do título de Mestre em \\ Engenharia Elétrica \\ Área de Concentração: \\ Sistemas Elétricos de Potência \\ Orientador: \\ Prof. Dr. Luiz Natal Rossi
}


Este exemplar foi revisado e alterado em relação à versão original, sob responsabilidade única do autor e com a anuência de seu orientador.

São Paulo, de junho de 2009.

Assinatura do autor

Assinatura do orientador

FICHA CATALOGRÁFICA

Gedra, Ricardo Luis

Análise de viabilidade financeira para obtenção de créditos de carbono em projetos de eficiência energética / R.L. Gedra. -ed.rev. -- São Paulo, 2009.

$113 \mathrm{p}$.

Dissertação (Mestrado) - Escola Politécnica da Universidade de São Paulo. Departamento de Engenharia de Energia e Automação Elétricas.

1. Energia elétrica (Eficiência) 2. Meio ambiente 3. Análise de risco (Viabilidade econômica) I. Universidade de São Paulo. Escola Politécnica. Departamento de Engenharia de Energia e Automação Elétricas II. t. 


\section{DEDICATÓRIA}

Aos meus pais André e Consiglia, ao meu irmão Marco e a minha esposa Adriana pelo apoio incondicional. 


\section{AGRADECIMENTOS}

Ao meu orientador, Prof. Dr. Luiz Natal Rossi, por todo o seu suporte, dedicação e contribuições para elaboração deste trabalho.

Aos meus colegas da AES-Eletropaulo Fernando Bacellar, Daniel Bento, Rubens Leme, Paulo Montalvão e Marcio Visini pelas preciosas contribuições colhidas durante a fase de desenvolvimento.

Aos meus pais que considero exemplo de vida e que sempre me incentivaram a estudar e a me desenvolver profissionalmente.

A minha esposa que sempre me apoiou mesmo durante minhas ausências dedicadas a elaboração deste trabalho. 


\section{RESUMO}

O presente trabalho tem por objetivo analisar a viabilidade financeira para obtenção de créditos de carbono em projetos de eficiência energética, por meio dos indicadores financeiros Valor Presente Líquido (VPL) e Taxa Interna de Retorno (TIR). A partir do desenvolvimento de uma modelagem analítica composta de despesas e receitas existentes em um determinado horizonte de tempo, obtém-se o fluxo caixa resultante do projeto, sobre o qual é calculado o VPL e a TIR em diferentes cenários de receitas advindas da venda dos créditos de carbono. Desta forma, pretende-se apresentar em quais condições a obtenção dos créditos de carbono aumenta o desempenho financeiro de um projeto de eficiência energética e em quais condições este desempenho é reduzido.

Palavras-chave: Eficiência energética. Crédito de carbono. Análise de viabilidade. 


\begin{abstract}
The present work has for objective to analyze the financial viability to obtain carbon credits in energy efficiency projects, through the financial indicators Net Present Value (NPV) and Internal Rate of Return (IRR). From the development of an analytical model composed of existing expenditure and revenue in a defined period of time, the cash flow resulting from the project is obtained, which is calculated on the NPV and IRR at different scenarios of revenue resulting from carbon credits. In such a way, it is intended to present in which conditions to obtain the carbon credits grow up the financial performance of a energy efficiency project and in which conditions this performance is reduced.
\end{abstract}

Key-words: Energy efficiency. Carbon credits. Viability analysis. 


\section{LISTA DE ILUSTRAÇÕES}

Figura 1 - Eficiência luminosa de lâmpadas 28

Figura 2 - Níveis mínimos de rendimento nominal de motores elétricos trifásicos de indução 31

Figura 3 - Emissões anuais de $\mathrm{CO}_{2}$ para cada $\mathrm{GW}$ de eletricidade gerado por tipo de fonte 34

Figura 4 - Fluxograma de tramitação de um projeto de MDL 37

Figura 5 - Percentual por pais das atividades de projetos de MDL no mundo 41

Figura 6 - Distribuição das atividades de projeto de MDL no Brasil por tipo 41

Figura 7 - Entidades financiadoras e possíveis beneficiários das RCEs de projetos de eficiência energética 45

Figura 8 - Estimativa do potencial de economia de energia elétrica no Brasil 51

Figura 9 - Comparativo de intensidade elétrica prevista até 2050 entre cenário de referência e cenário de revolução energética 53

Figura 10 - Venda anual dos créditos de carbono 55

Figura 11 - Venda dos créditos de carbono de uma única vez após recebimento das RCES 55

Figura 12 - Venda dos créditos de carbono de uma única vez no início do projeto 56

Figura 13 - Exemplo de curva de duração da carga de um Sistema Elétrico 59

Figura 14 - Fluxo de caixa de um projeto de eficiência energética com MDL 64

Figura 15 - Resumo dos projetos do PEE nos ciclos 2005/2006 e 2006/2007 78

Figura 16 - Energia negociada nos leilões de novas usinas com entrada em operação entre janeiro de 2008 e janeiro de 2013 89

Figura 17 - Emissões de $\mathrm{CO}_{2}$ equivalente de usina de energia elétrica por tipo de fonte 


\section{LISTA DE GRÁFICOS}

Gráfico 1 - VPL de projetos de eficiência energética de 1 a 15 GWh com e sem créditos de carbono no cenário de referência. 80

Gráfico 2 - TIR de projetos de eficiência energética de 1 a 15 GWh com e sem créditos de carbono no cenário de referência

Gráfico 3 - VPL de projetos de eficiência energética de 1 a 15 GWh com e sem créditos de carbono no cenário pessimista 82 Gráfico 4 - TIR de projetos de eficiência energética de 1 a 15 GWh com e sem créditos de carbono no cenário pessimista

Gráfico 5 - VPL de projetos de eficiência energética de 1 a 15 GWh com e sem créditos de carbono no cenário otimista 84

Gráfico 6 - TIR de projetos de eficiência energética de 1 a 15 GWh com e sem créditos de carbono no cenário otimista 85 Gráfico 7 - VPL de projetos de eficiência energética de 1 a 15 GWh com e sem créditos de carbono considerando $50 \%$ de redução nos custos das auditorias ...... 86 Gráfico 8 - TIR de projetos de eficiência energética de 1 a 15 GWh com e sem créditos de carbono considerando $50 \%$ de redução nos custos das auditorias 87 Gráfico 9 - VPL de projetos de eficiência energética de 1 a 15 GWh com e sem créditos de carbono considerando o preço de venda da RCE de $€ 40,00$ 88 Gráfico 10 - TIR de projetos de eficiência energética de 1 a 15 GWh com e sem créditos de carbono considerando o preço de venda da RCE de €40,00 88 Gráfico 11 - VPL de projetos de eficiência energética de 1 a 15 GWh com e sem créditos de carbono considerando o fator de emissão de $1 \mathrm{tCO}_{2} / \mathrm{MWh}$ 90 Gráfico 12 - TIR de projetos de eficiência energética de 1 a 15 GWh com e sem créditos de carbono considerando o fator de emissão de $1 \mathrm{tCO} / \mathrm{MWh}$ 


\section{LISTA DE TABELAS}

Tabela 1 - Fator de emissão de $\mathrm{CO}_{2}$ de usina de energia elétrica por tipo de fonte 49

Tabela 2 - Fator de emissão para o subsistema Sul, Sudeste e Centro Oeste do Sistema Interligado Nacional - Ano base 2005 60

Tabela 3 - Fator de emissão para o subsistema Norte e Nordeste do Sistema Interligado Nacional - Ano base 2005 60

Tabela 4 - Fluxo de caixa e cálculo da VPL e da TIR do projeto de eficiência energética da SAMAE com e sem MDL

Tabela 5 - Fluxo de caixa e cálculo da VPL e da TIR do projeto de eficiência energética da Prefeitura de Recife com e sem MDL 73

Tabela 6 - Fluxo de caixa e cálculo da VPL e da TIR do projeto de eficiência energética em sistemas de bombeamento da CPFL com e sem MDL 75 Tabela 7 - Fluxo de caixa e cálculo da VPL e da TIR do projeto de eficiência energética em entidades educacionais da AES-Eletropaulo com e sem MDL 77

Tabela 8 - Relação média entre investimento e economia de energia e entre investimento e redução de demanda em projetos de eficiência energética 79 Tabela 9 - Fator de emissão médio no Sistema Interligado Nacional em $\mathrm{tCO}_{2} / \mathrm{MWh}$ considerando somente a margem de operação. 


\section{LISTA DE ABREVIATURAS E SIGLAS}

$\begin{array}{ll}\text { Abesco } & \text { Associação Brasileira das Empresas de Conservação de Energia } \\ \text { Abinee } & \text { Associação Brasileira da Indústria Elétrica e Eletrônica } \\ \text { AND } & \text { Autoridade Nacional Designada } \\ \text { Aneel } & \text { Agência Nacional de Energia Elétrica } \\ \text { BNDES } & \text { Banco Nacional de Desenvolvimento Econômico e Social } \\ \text { Chesf } & \text { Companhia Hidro Elétrica do São Francisco } \\ \text { Conpet } & \text { Programa Nacional da Racionalização do Uso dos Derivados do } \\ & \text { Petróleo e do Gás Natural } \\ \text { COP } & \text { Conferência das Partes } \\ \text { DCP } & \text { Documento de Concepção de Projeto } \\ \text { EGTD } & \text { Energia Garantida por Tempo Determinado } \\ \text { EOD } & \text { Entidade Operacional Designada } \\ \text { Esco } & \text { Energy Service Company } \\ \text { GEE } & \text { Gases de Efeito Estufa } \\ \text { IPCC } & \text { Intergovernmental Pannel on Climate Change } \\ \text { MDL } & \text { Mecanismo de Desenvolvimento Limpo } \\ \text { MPEE } & \text { Manual para Elaboração do Programa de Eficiência Energética } \\ \text { OMM } & \text { Organização Meteorológica Mundial } \\ \text { ONS } & \text { Operador Nacional do Sistema } \\ \text { PEE } & \text { Programa Anual de Eficiência Energética } \\ \text { PND } & \text { Programa Nacional de Desestatização } \\ \text { PNE } & \text { Plano Nacional de Energia } \\ \text { Pnuma } & \text { Programa das Nações Unidas para o Meio Ambiente } \\ \text { Procel } & \text { Programa Nacional de Conservação de Energia Elétrica } \\ \text { P\&D } & \text { Pesquisa e Desenvolvimento } \\ \text { RCB } & \text { Relação Custo Benefício } \\ \text { RCE } & \text { Redução Certificada de Emissão } \\ \text { Reseb } & \text { Programa de Reestruturação do Setor Elétrico Brasileiro } \\ \text { ROL } & \text { Receita Operacional Líquida } \\ \text { TIR } & \text { Taxa Interna de Retorno } \\ \text { UNFCCC } & \text { United Nations Framework Convention on Climate Change } \\ \text { VPL } & \text { Valor Presente Líquido } \\ & \end{array}$




\section{SUMÁRIO}

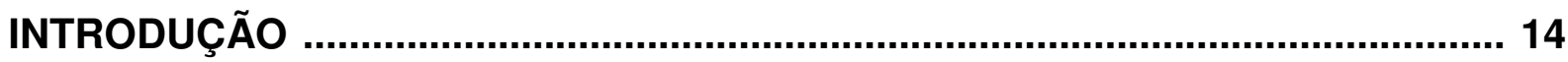

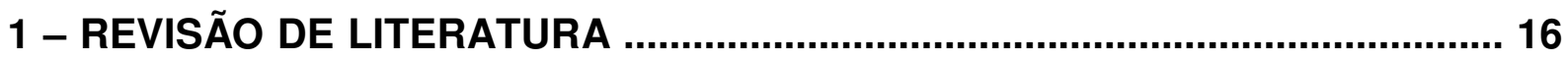

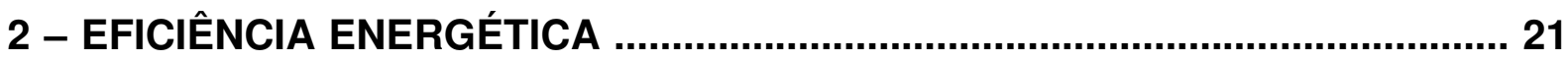

2.1 - Aspectos históricos da eficiência energética no Brasil ............................. 21

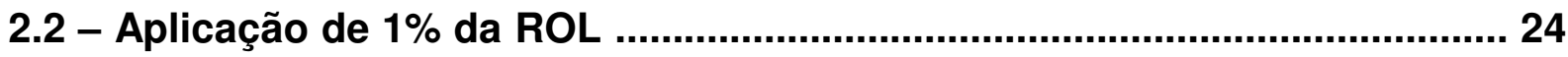

2.3 - Tipos de projetos de eficiência energética ................................................. 26

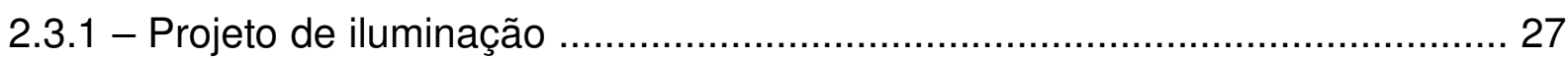

2.3.2 - Projeto de climatização ambiental ....................................................... 29

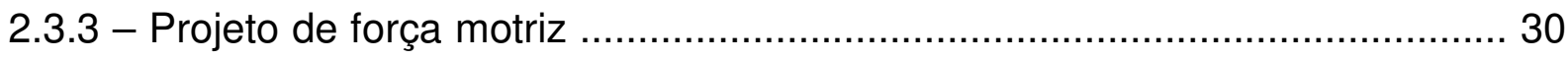

3 - PROTOCOLO DE QUIOTO

3.1 - Mecanismo de desenvolvimento limpo - MDL …...................................... 35

3.1.1 - Apresentação de um projeto de MDL ………....................................... 36

3.1.2 - Projetos de MDL do Brasil ........................................................... 40

4 - OBTENÇÃO DE CRÉDITOS DE CARBONO COM PROJETOS DE EFICIÊNCIA

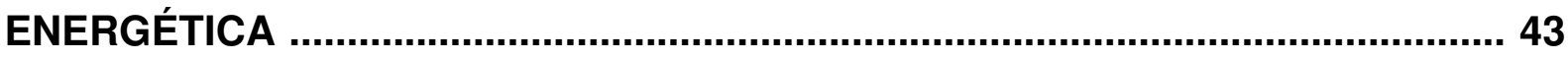

4.1 - Critérios de elegibilidade de projetos de MDL .......................................... 43

4.2 - Propriedade das RCEs .............................................................................. 44

4.2.1 - Projetos financiados pelo PEE com as RCEs para as distribuidoras ........... 46

4.2.2 - Projetos financiados pelo PEE com as RCEs para os consumidores .......... 47

4.2.3 - Projetos financiados por agente financeiro ou fundo setorial ..................... 47

4.3 - Potencial de créditos de carbono ........................................................... 48

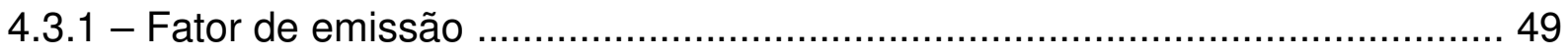

4.3.2 - Cenário atual do potencial de créditos de carbono ……........................ 51

4.3.3 - Cenário futuro do potencial de créditos de carbono ……...................... 52

5 - INFLUÊNCIA DOS CRÉDITOS DE CARBONO NA VIABILIDADE FNANCEIRA

5.1 - Decisão sobre o momento de venda das RCEs ....................................... 54

5.2 - Metodologia da linha de base e do monitoramento .................................. 56

5.2.1 - Cálculo do fator de emissão a partir da metodologia ACM0002 ................. 57

5.3 - Modelagem da análise de viabilidade .....................................................60

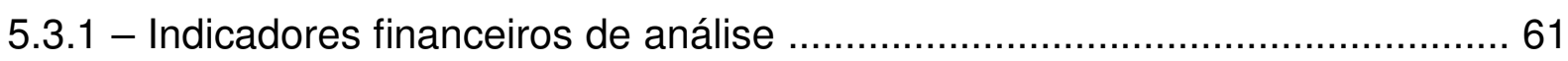

5.3 .2 - Elaboração do fluxo de caixa ……………......................................... 63 
5.3.3 - Redução da despesa com energia elétrica ………………................... 64

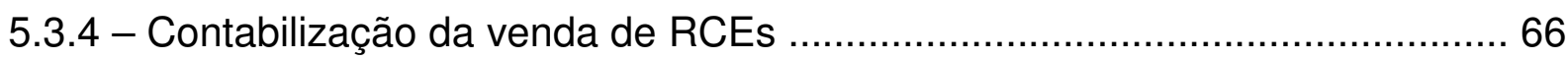

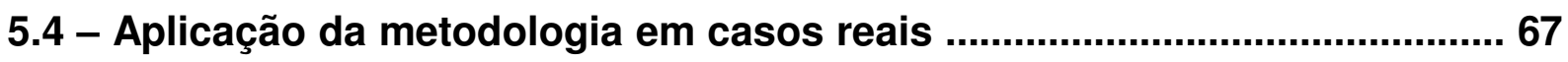

5.4.1 - Sistema de bombeamento da SAMAE de Caxias do Sul ............................ 69

5.4.2 - Sistema de ar condicionado da Prefeitura de Recife ................................. 72

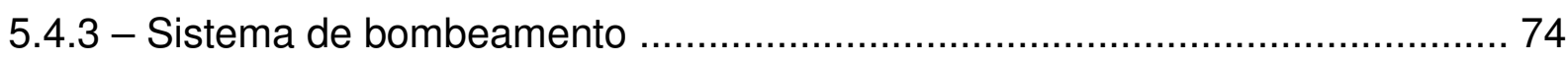

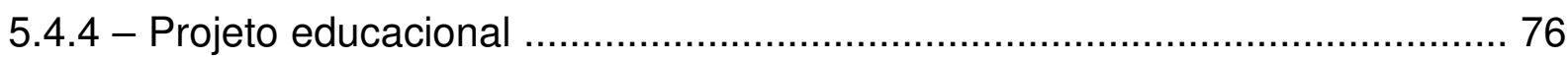

5.5 - Limite de viabilidade para obtenção de créditos de carbono ................... 78

5.5.1 - Cenário de Referência ...................................................................... 80

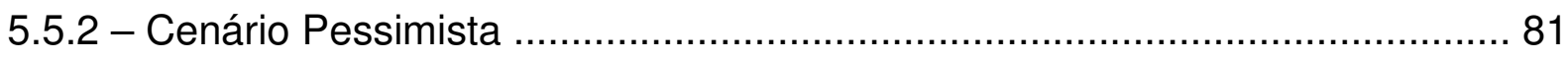

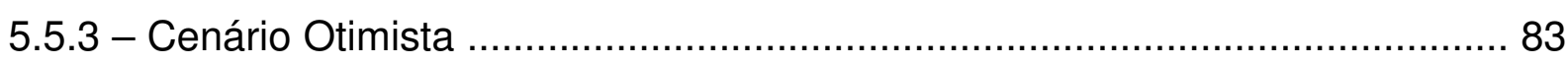

5.6 - Análise da viabilidade com extrapolação de parâmetros .......................... 85

5.6.1 - Redução dos custos com auditoria .................................................... 86

5.6.2 - Aumento do preço do crédito de carbono ............................................. 87

5.6.3 - Aumento do fator de emissão ……………........................................ 89

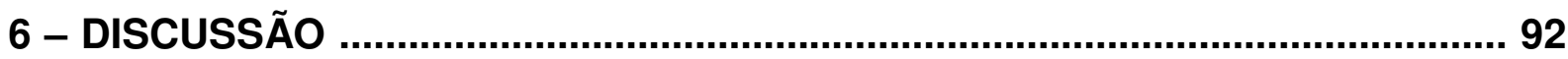

6.1 - Discussão da aplicação da metodologia em casos reais ......................... 92

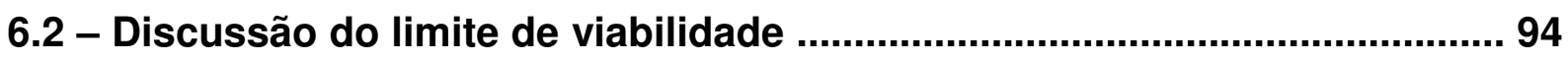

6.3 - Discussão da extrapolação de parâmetros ………….............................. 95

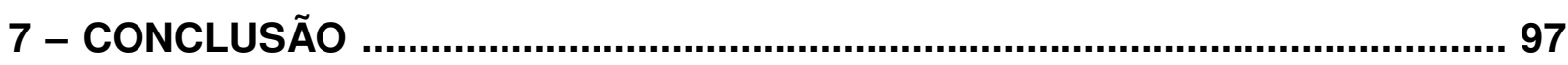

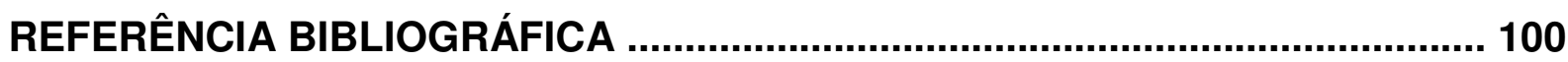

ANEXO A - Fórmulas da modelagem da análise de viabilidade ...................... 106 


\section{INTRODUÇÃO}

Os projetos de eficiência energética possuem como principal objetivo a redução do consumo de energia de uma determinada instalação, sem promover decréscimo em sua produção ou prestação de serviço. Conceitualmente, este tipo de projeto pode ser realizado em processos que consumam qualquer tipo de energia, porém este trabalho atua especificamente em projetos direcionados a tornar mais eficiente a utilização da energia elétrica.

Quando um processo é transformado tornando-se mais eficiente, reduz-se o consumo de energia elétrica necessário para se produzir o mesmo resultado. Esta redução no consumo de energia não reflete diretamente em uma redução da emissão de gases causadores do efeito estufa, mas promove uma redução indireta devido aos gases que deixam de ser emitidos pela energia elétrica que não precisa ser gerada.

Desta forma, a realização do projeto de eficiência energética também promove uma redução na emissão dos Gases de Efeito Estufa - GEE, o que pode se tornar uma fonte de receita pela venda dos créditos de carbono, além da própria redução na conta da energia elétrica. Entretanto, para que um projeto tenha o direito de comercializar créditos de carbono, se faz necessário atender algumas exigências definidas no Protocolo de Quioto, demandando despesas adicionais.

Em contrapartida a este aumento de despesa, há um aumento da receita em função da venda dos créditos de carbono. A questão é saber se estas despesas e receitas adicionais aumentam ou reduzem o desempenho financeiro de um projeto de eficiência energética.

Este trabalho faz uma análise financeira de projetos de eficiência energética, utilizando inclusive exemplos de projetos já realizados no país, calculando os indicadores financeiros VPL e TIR a partir de um fluxo de caixa que contabiliza as despesas e receitas existentes em um horizonte de dez anos.

Sobre o projeto original de eficiência energética, são inseridas as despesas e receitas referentes à obtenção de créditos de carbono e novamente são realizados os cálculos do VPL e da TIR sobre o novo fluxo de caixa. 
Os indicadores financeiros calculados nas duas situações são sobrepostos graficamente, obtendo uma análise comparativa da influência dos créditos de carbono na viabilidade financeira de projetos de eficiência energética.

Para que seja atingido este objetivo o trabalho está estruturado em 7 capítulos, sendo que o capítulo 1 é dedicado a uma revisão bibliográfica acerca do tema. 0 capítulo 2 busca circunstanciar a questão da eficiência energética, analisando os tipos de projetos e seus usos finais de energia.

O capítulo 3 é dedicado a explicar de forma sucinta o que é o Protocolo de Quioto e, de forma um pouco mais detalhada, aborda um dispositivo criado neste protocolo que é o Mecanismo de Desenvolvimento Limpo - MDL, por meio do qual são comercializados os créditos de carbono.

No capítulo 4 são aplicados os temas estudados nos dois capítulos anteriores, analisando de que forma, e em quais situações, um projeto de eficiência energética é capaz de gerar créditos de carbono. Complementarmente, é realizada uma análise do potencial teórico de geração de créditos de carbono no país.

A forma como os créditos de carbono impactam na viabilidade financeira do projeto de eficiência energética é estudada no capítulo 5. Para realizar esta análise desenvolveu-se uma modelagem sobre a qual são realizadas simulações de quatro projetos de eficiência energética já realizados no país. Este capítulo define ainda três cenários de receitas advindas dos créditos de carbono e simula a realização de projetos de eficiência energética de diversos portes dentro de cada cenário, apresentando em quais condições o seu desempenho financeiro é aumentado.

O capítulo 6 faz uma discussão dos resultados e o capítulo 7 apresenta a conclusão do trabalho. A modelagem desenvolvida no capítulo 5 é apresentada de forma detalhada no Anexo A. 


\section{1 - REVISÃO DE LITERATURA}

A eficiência energética é um tema que tem apresentado grande destaque em discussões por todo o mundo, e este processo incentiva a elaboração de estudos e conseqüentes publicações de literaturas acerca do tema. Entretanto, nota-se uma dificuldade na transposição da barreira existente entre os conceitos das publicações teóricas e sua aplicação na vida prática, conforme relatado por Raad e Schechtman (1996, p. 2.051) "Na prática, uma série de barreiras ou imperfeições de mercado agem no sentido de dificultar, retardar, e até mesmo inibir a penetração de medidas, tecnológicas ou programas para utilização mais eficiente da energia.".

Apesar da grande importância da questão, nota-se ainda uma resistência por parte de empresários na aquisição de equipamentos e desenvolvimento de processos de elevada eficiência. "Experiências internacionais mostram que, geralmente, regras de mercado não são suficientes para a efetiva implantação de ações em direção à conservação de energia." (RAAD; SCHECHTMAN, 1996, p. 2.051). Taylor et al. corrobora com esta opinião e completa:

\footnotetext{
As principais ferramentas para promover a eficiência energética em novas instalações são questões políticas e regulatórias (incluindo programa de subsidio, se permitido) para aumentar o incentivo a investidores tomarem suas decisões separadamente da decisão de investimento. (TAYLOR et al. 2008 , p. 42, tradução nossa)
}

Taylor et al. (2008, p. 43) ainda salienta que em determinadas situações, nas quais a implantação de equipamentos de elevada eficiência impactam diretamente nos custos de produção de uma empresa, o aspecto da eficiência energética se torna de fácil compreensão aos empresários e o projeto é facilmente aprovado, entretanto, quando essa relação não é direta ou é imperceptível, torna-se mais difícil a viabilização do projeto.

A Eletrobrás chama a atenção de como a eficiência deve estar alinhada com o objetivo estratégico da instituição: "Uma empresa que deseja alcançar uma estrutura de custos racionalizada e tornar-se mais competitiva não pode admitir o desperdício ou usar a energia de forma ineficiente e irresponsável.”. (ELETROBRÁS, 2005, p. 9). Zachar (1984, p. 262, tradução nossa) completa a afirmação "O gerenciamento de energia precisa estar inserido na missão da organização [...]" 
Antes que seja tomada qualquer ação de gerenciamento de energia é importante que seja realizado um trabalho coordenado, a fim de que se tenha uma gestão das ações que estão sendo tomadas dentro da empresa. Eletrobrás (2005, p. 13) define que a gestão energética de uma instalação compreende as seguintes medidas.

\begin{abstract}
- Conhecer as informações sobre fluxos de energia, regras, contratos e ações que afetam esses fluxos; os processos e atividades que usam energia, gerando um produto ou serviço mensurável; e as possibilidades de economia de energia.

- Acompanhar os índices de controle, como: consumo de energia (absoluto e específico), custos específicos, preços médios, valores contratados, registrados e faturados, e fatores de utilização dos equipamentos e/ou da instalação.

- Atuar no sentido de medir os itens de controle, indicar correções, propor alterações, auxiliar na contratação de melhorias, implementar ou acompanhar as melhorias, motivar os usuários da instalação a usar racionalmente a energia, divulgar ações e resultados, buscar capacitação adequada para todos e prestar esclarecimentos sobre as ações e seus resultados. (ELETROBRÁS, 2005, p. 13)
\end{abstract}

Somente com um trabalho amplo de gestão energética instaurado na empresa e com o apoio da alta direção é possível realizar um mapeamento completo das perdas existentes e identificar precisamente todos os usos finais de energia que possuem potencial de se tornarem mais eficientes.

O trabalho de gestão energética pode mapear ações a serem tomadas que necessitem de aporte de recursos para aquisição de novos equipamentos e modernização de processos. Para se obter esses recursos o projeto precisa apresentar uma viabilidade a fim de justificar a sua implantação, portanto, comumente estes projetos passam por um estudo técnico e econômico de viabilidade, que é definido por Keelling (2006, p. 45) da seguinte maneira "O estudo de viabilidade é um dos passos mais importantes para o sucesso no desenvolvimento do projeto [...]".

Keelling (2006, p. 47) ainda completa o destaque e a importância deste estudo: "Há uma grande chance de o estudo de viabilidade se tornar o fundamento sobre o qual a definição e as justificativas do projeto serão baseadas [...]". É possível notar pelo destaque apresentado por Keeling, que o estudo de viabilidade poderá se tornar o principal indicador de acompanhamento do projeto pelas partes envolvidas.

Eventualmente, um projeto de eficiência energética pode demandar recursos indisponíveis na instituição, sendo que neste caso se faz necessário um financiamento. Os modelos de financiamento existentes no mercado podem não se adequar as necessidades de um projeto desta natureza no que se refere ao valor 
financiado, prazo de pagamento, período de carência, dentre outros, o que deixaria o mercado carente de recursos. A fim de equacionar este problema se faz necessária a adequação dos financiamentos, conforme destacado por Taylor et al. (2008, p.12 tradução nossa) "[...] Modificações das linhas de financiamento, para se adequar as características dos projetos de eficiência energética, podem ajudar a expandir este mercado, viabilizando financeiramente a implementação de projetos."

Para atender a estas características o Banco Nacional de Desenvolvimento Econômico e Social - BNDES criou o Proesco, que é uma linha de financiamento com características modeladas de acordo com as necessidades dos projetos de eficiência energética.

O fato de o BNDES ter criado uma linha de financiamento específico, apresenta-se como um grande apoio ao fomento de projetos, entretanto, segundo Januzzi, este fato demonstra que este mercado ainda não está maduro e sustentável, "Um mercado se torna sustentável quando não requer apoio externo na forma de subsídios [...]" (JANUZZI, et al. 2001a, p. 1). Para se tornar sustentável Januzzi et al apresenta quatro pilares que precisam ser desenvolvidos e amadurecidos:

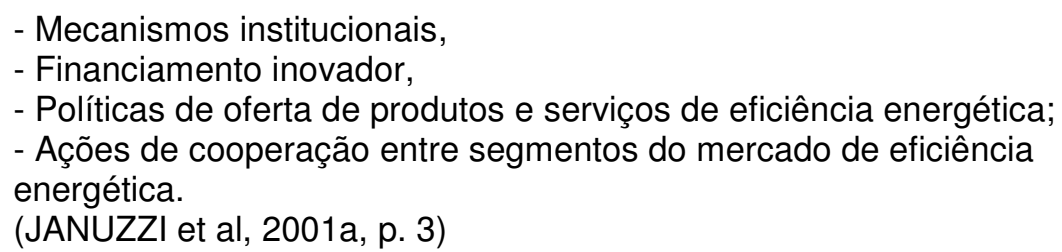

Para se ter uma idéia do potencial que uma medida política possui sobre o mercado, Geller et al. (2004, p. 1.448, tradução nossa) afirma que no Brasil "O uso nacional de energia poderia ser reduzido em aproximadamente $12,5 \%$ em 2010 se políticas forem adotadas e efetivamente implantadas." Por sua vez Januzzi et al.( 2001a, p. 42) define a questão política como sendo "[...] um conjunto de programas e atividades integradas e coordenadas de eficiência energética, capazes de maximizar os benefícios aos grupos sociais e atingir metas de economias de energia".

Analisando ainda o aspecto político, investir em eficiência energética otimiza muito mais o recurso em comparação ao investimento em geração. Eletrobrás (2001, p. 97) afirma que para economizar 1 MWh é necessário investir de 5 a 15US\$ em um projeto de eficiência energética, entretanto, para gerar o mesmo $1 \mathrm{MWh}$ é necessário investir 60US\$ na construção de uma usina convencional. 
Um dos mecanismos políticos mais conhecidos e utilizados no Brasil ao fomento da realização de projetos de eficiência energética é a obrigatoriedade das distribuidoras de energia elétrica em aplicarem $1 \%$ de sua Receita Operacional Líquida - ROL em projetos de eficiência energética e de pesquisa e desenvolvimento. A parcela destinada aos projetos de eficiência energética deve ser aplicada em clientes da própria distribuidora, cobrindo todos os custos de materiais e serviços necessários para a execução do projeto.

Para que seja possível realizar uma transformação no mercado de eficiência energética, Januzzi et al (2001a, p. 60-61) recomenda que estes projetos sejam plurianuais, de três a cinco anos, e concentrados em determinados setores, para que as empresas beneficiadas se tornem referência no uso racional de energia em seu segmento de atuação. Este mesmo conceito é abordado por Sebrae (2003, p. 41) com o título de "Unidade de Demonstração" onde empresas de determinados setores recebem projetos de eficiência energética, amparados por consultores especializados, tornando-se modelo para as demais.

Geller et al. (2004, p. 1.441, tradução nossa) propõem uma medida mais arrojada na política de aplicação do recurso obrigatório das distribuidoras de energia elétrica:

\footnotetext{
Essa política poderia expandir o fundo dos programas de eficiência energética no Brasil para cerca de $2 \%$ da receita das concessionárias. [...] Parte deste dinheiro poderia ser investido diretamente pelas concessionárias e a outra parte investido pelo governo, por meio de um programa nacional de eficiência energética. (GELLER et al., 2004, p. 1.441, tradução nossa)
}

Contrapondo esta metodologia de aplicação e gestão deste recurso por parte das distribuidoras, Januzzi et al (2001a, p. 124-125) propõe que o sistema de remuneração das distribuidoras seja alterado do atual modo de Preço-Limite, na qual a receita da distribuidora é obtida através da multiplicação entre a quantidade de energia distribuída pela tarifa, para o modo de Receita-Limite, na qual a receita média de cada consumidor é mantida a cada ano e as reduções no consumo da energia, advinda da eficiência energética, transformam-se em um ganho adicional, desta forma as distribuidoras de energia elétrica teriam maior interesse em promover a eficiência energética além dos limites mínimos obrigatórios da regulamentação.

Esta proposta necessitaria de uma grande reforma em todo o setor elétrico e criaria um motivador financeiro para execução de projetos de eficiência energética por parte das distribuidoras. 
Outra proposta de Januzzi et al (2001a, p. 132-133) sugere retirar das distribuidoras a responsabilidade da realização dos projetos de eficiência energética, direcionando o recurso de $1 \%$ de sua $\mathrm{ROL}$ para uma concessionária nacional, que seria criada com o objetivo de promover projetos de eficiência energética e de pesquisa e desenvolvimento.

Independentemente da origem do recurso, a execução de projetos de eficiência energética geralmente é realizada por empresas de conservação de energia conhecidas como Energy Service Company - Esco. Essas empresas atuam na estruturação e execução do projeto, seja financiado pelas distribuidoras, pelo consumidor de energia, por instituições financeiras ou com recursos próprios.

Como estas empresas são carentes de recursos, Taylor et al. (2008, p. 16, tradução nossa) destaca que "Financiamento de longo prazo para Escos deveriam ser considerados como um grande incentivo para promover o desenvolvimento do mercado local de Escos.", afinal, são estas empresas que prospectam e executam grande parte dos projetos de uso racional de energia, portanto é de grande importância que elas tenham acesso aos recursos para realização dos projetos.

Outro mecanismo político existente no Brasil para disseminação da eficiência energética é o Programa Nacional de Conservação de Energia Elétrica - Procel. Todas as suas ações estruturadas no ano de 2006 economizaram 2.845 GWh e o montante acumulado desde 1986 até 2006 totaliza uma economia de 24.598 GWh (PROCEL, 2007, p. 24).

O Procel também atua em outras áreas com os seguintes programas: Procel Educação, Gestão Energética Municipal, Reluz e ações de Marketing, mas o Selo Procel se destaca com 87,2\% das economias obtidas em 2006 (PROCEL, 2007, p. 25). 


\section{2 - EFICIÊNCIA ENERGÉTICA}

\section{1 - Aspectos históricos da eficiência energética no Brasil}

No início do período da eletrificação praticamente não havia preocupação com a eficiência no uso da energia elétrica, sendo a maior parte das atenções dedicadas ao atendimento da expansão do mercado consumidor. Esse fato é comprovado pela criação do Código de Águas em 1934 que federalizou o poder concedente, com o objetivo de sanar os problemas de suprimento, regulamentação e tarifação existentes no setor elétrico.

Em 1945 foi criada a Companhia Hidro Elétrica do São Francisco - Chesf, a primeira empresa de eletricidade do Governo Federal que construiu a Usina Hidroelétrica Paulo Afonso I, em 1954, no Rio São Francisco.

A década de 50 foi marcada por uma crise energética na Região Sudeste, o que forçou o Governo a criar em 1957 a Central Elétrica de Furnas S.A., com o objetivo expresso de aproveitar o potencial hídrico do Rio Grande, e em 1963 entrou em operação a Usina Hidroelétrica de Furnas, que na época era a maior usina do país. Com o intuito de unir sob uma holding as duas grandes empresas estatais, Chesf e Furnas, surge em 1961 a Eletrobrás - Centrais Elétricas Brasileiras.

Em 1973 foi firmado o acordo entre Brasil e Paraguai para a construção da Usina Binacional de Itaipu que veio a entrar em operação somente em 1984 e no ano seguinte, em 1985, entrou em operação a Usina Termonuclear de Angra I.

No ano de 1981 o governo federal lançou o programa Conserve, que tinha como objetivo promover a conservação de energia. Foram desenvolvidos protocolos que produziram resultados sobre a eficiência energética em setores como os de cimento, siderurgia e papel/celulose, entretanto, o que se verificou foi a predominância de um enfoque na substituição energética.

Este direcionamento do programa foi parcialmente motivado pela recessão econômica ocorrida em 1981, que culminou em uma redução da demanda por energia elétrica, ocasionando ociosidade da capacidade instalada do parque gerador do país. Para aproveitar esse excesso de capacidade, surgido após a segunda crise 
do petróleo ocorrida em 1979, o programa Conserve criou a Energia Garantida por Tempo Determinado - EGTD, que concedia desconto de $30 \%$ sobre a tarifa de energia elétrica praticada na época. Tendo como alvo o setor industrial, concedia este benefício tarifário para indústrias que substituíssem equipamentos que consumiam óleo (caldeiras e fornos, por exemplo) para equipamentos similares alimentados por energia elétrica. Este benefício foi garantido até 1986, permitindo a amortização dos investimentos na instalação ou conversão de equipamentos pelas indústrias.

Com a participação das três empresas que na época eram as principais distribuidoras de energia elétrica do Estado de São Paulo, Eletropaulo, CESP e CPFL mais a empresa de gás do Estado COMGÁS, foi criada em 1983 a Agência para Aplicação de Energia.

A Agência possuía como missão coordenar as ações relativas ao aumento da eficiência energética nos setores produtivos do Estado de São Paulo, orientando e supervisionando a atuação das empresas de energia.

Complementarmente, a Agência coordenava as ações de desenvolvimento tecnológico realizadas pelas quatro empresas, nas áreas de armazenamento, produção, transformação, transporte e distribuição de energia e articulava 0 processo de obtenção de recursos para programas de desenvolvimento tecnológico e de aumento da eficiência energética nos setores de produção e no uso final.

A Agência também ficou caracterizada pela publicação e distribuição de manuais destinados à conservação de energia para os vários setores da sociedade.

No ano de 1984 foi assinado um protocolo entre o Ministério da Indústria e do Comércio e a Associação Brasileira da Indústria Elétrica e Eletrônica - Abinee, com a interveniência do Ministério de Minas e Energia, que instituiu o Programa Brasileiro de Etiquetagem, com o objetivo de alertar o consumidor quanto à eficiência energética dos principais eletrodomésticos e equipamentos residenciais e industriais comercializados no país.

A década de 80 foi marcada por uma crise no setor elétrico causada em grande parte pelo lançamento do Plano Cruzado, que dispunha como uma de suas medidas o congelamento das tarifas das distribuidoras de energia elétrica, com o intuito de tentar conter a inflação. Esse fato fez com que o valor da energia pago pelos consumidores estivesse defasado em relação aos custos operacionais das empresas distribuidoras, que nesse cenário mal tinham condição de honrar seus 
compromissos financeiros e, portanto, não tinham condição de investir em projetos de eficiência energética.

Essa crise também afetou os setores de geração e transmissão que recebiam poucos investimentos, o que acabou culminando em dois racionamentos, um na Região Sul em 1986 e outro na Região Nordeste em 1987. Os já previsíveis racionamentos fizeram com que o Governo, pouco antes, em dezembro de 1985, criasse o Procel com o intuito de tornar mais eficiente o consumo de energia elétrica no país, a partir de ações coordenadas por este programa. A criação do Procel foi um marco do início de uma conscientização nacional da importância do uso racional da energia elétrica.

Inicialmente o Procel era gerido por uma Secretaria Executiva subordinada à Eletrobrás e contava com recursos próprios para aplicação nos projetos de eficiência energética, mas em julho de 1991 ele foi transformado em um programa de Governo, tendo a sua abrangência e responsabilidade ampliadas.

No mesmo ano de 1991 foi criado o Programa Nacional da Racionalização do Uso dos Derivados do Petróleo e do Gás Natural - Conpet, com o objetivo de incentivar o uso eficiente dos derivados do petróleo e do gás natural. Posteriormente foi criado um programa de etiquetagem de fogões e fornos domésticos a gás.

Um dos importantes trabalhos do Procel foi a criação do Selo Procel, em 1993, com o objetivo indicar ao consumidor os produtos que apresentam os melhores níveis de eficiência energética dentro da sua categoria.

Em 1995 foi concluído o Programa de Reestruturação do Setor Elétrico Brasileiro Reseb que continha, dentre outras ações, o Programa Nacional de Desestatização PND.

O programa Reseb tinha como um dos seus objetivos desverticalizar e privatizar as empresas do setor elétrico, implantando um mercado competitivo onde possível e regulado onde necessário. Alguns dos principais objetivos do programa eram propiciar aos consumidores uma tarifa módica e garantir que o país fosse suprido de energia suficiente para abastecer o seu desenvolvimento, através do fomento a investimentos privados na expansão do sistema.

Como resultado deste trabalho as empresas verticalizadas foram desmembradas em empresas de geração, transmissão e distribuição e foi criada uma quarta categoria de empresa chamada de comercializadora. Alguns grupos empresariais mantiveram sob uma holding empresas atuantes em diferentes segmentos (geração e 
distribuição, por exemplo), porém juridicamente e contabilmente como empresas distintas.

As empresas de geração e comercialização atuam em um mercado livre e competitivo, entretanto, as empresas de distribuição e transmissão são totalmente reguladas. Para regulamentar e fiscalizar as empresas desverticalizadas foi criada a Agência Nacional de Energia Elétrica - Aneel em dezembro de 1996.

Com esse cenário já não era mais coerente o governo, através da Eletrobrás e do Procel, transferir recursos para as distribuidoras privadas investirem em projetos de eficiência energética e, por outro lado, nenhuma distribuidora privada iria investir por vontade própria em uma medida de eficiência energética que pode reduzir o seu faturamento.

Outra lacuna existente na época se refere ao investimento em Pesquisa e Desenvolvimento - P\&D por parte das empresas privadas, uma vez que nesse tipo de projeto comumente não há retorno do investimento, ou em alguns casos este retorno ocorre somente a longo prazo, o que geralmente não é aceito pelos investidores. Portanto, era necessário estabelecer algum mecanismo que incentivasse a pesquisa de novas tecnologias para garantir o desenvolvimento do país no setor elétrico.

Com o intuito de evitar a extinção das ações de eficiência energética no país e manter ativo o fomento às entidades de pesquisa, o programa Reseb previa que $1 \%$ da ROL das distribuidoras deveria ser investido em projetos de eficiência energética e em P\&D.

\section{2 - Aplicação de $1 \%$ da ROL}

O contrato de concessão das distribuidoras, privatizadas no final da década de 90, previa que $1 \%$ de sua ROL fosse aplicado em programas de eficiência energética e de pesquisa e desenvolvimento.

Quarta Subcláusula - A CONCESSIONÁRIA implementará medidas que tenham por objetivo a conservação e o combate ao desperdício de energia, bem como pesquisa e desenvolvimento tecnológico do setor elétrico, devendo elaborar, para cada ano subsequente, programa de incremento à eficiência no uso e na oferta de energia elétrica que contemple a aplicação 
de recursos de, no mínimo, 1\% (um por cento) da Receita Anual ( RA0), calculada segundo a Sexta Subcláusula da Cláusula Sétima. Deste montante, pelo menos $1 / 4$ (um quarto) deverá ser vinculado a ações especificamente ligadas ao uso final da energia elétrica e 0,1\% (um décimo por cento) da Receita Anual ( RA0 ) ser destinado à aplicação no Brasil em pesquisa e desenvolvimento tecnológico do setor elétrico. É facultado à CONCESSIONÁRIA a aplicação de montante superior a 1\% (um por cento) da Receita Anual ( RAO ) no referido programa. Esse programa anual, que contém metas físicas e respectivos orçamentos, deverá ter como objetivo a redução das perdas técnicas e comerciais globais, bem como ações específicas voltadas ao uso da energia de forma racional e eficiente por parte dos consumidores e ser apresentado a Aneel até 30 de setembro de cada ano. (CONTRATO DE CONCESSÃO DA ELETROPAULO, 1998)

Embora o Contrato de Concessão determine a aplicação de 1\% da ROL em projetos de eficiência energética e de $P \& D$, ele não deixa claro como deve ser 0 fracionamento deste recurso em ambos os tipos de projetos.

Para resolver esse problema, em Julho de 2000 foi publicada a Lei 9.991 que determina o percentual mínimo de aplicação de $0,5 \%$ da ROL de uma distribuidora em seu Programa Anual de Eficiência Energética - PEE até 31/12/2005 e os 0,5\% complementares devem ser aplicados em projetos de P\&D, após esta data 0 percentual mínimo de aplicação em eficiência energética muda para $0,25 \%$ da ROL e em P\&D para $0,75 \%$ da ROL.

Em virtude do racionamento de energia elétrica ocorrido em 2001, que exigia uma redução imediata no consumo, buscando compatibilizar a relação entre a demanda e a oferta de energia elétrica no país, a Aneel publicou a Resolução 153 em abril de 2001 que determinava a conversão do PEE do Ciclo 2000/2001 em doação de lâmpadas fluorescentes compactas.

Pouco tempo depois, em maio de 2001, a Aneel publicou a Resolução 186 que complementava a Resolução 153 permitindo que as distribuidoras investissem também os recursos do PEE em projetos de iluminação pública.

No ano seguinte as distribuidoras foram liberadas a executar projetos de eficiência energética tradicionais, porém restritos somente ao uso final da energia elétrica, sendo que os projetos pelo lado da oferta (Ex. Substituição de um condutor convencional por outro de maior seção para reduzir a perda na transmissão) não foram mais permitidos. Esse fato ficou documentado pela Resolução 492 de setembro de 2002.

Em novembro de 2005 a Aneel publicou a Resolução 176 que determina que no mínimo $50 \%$ dos recursos destinados aos projetos de eficiência energética devam ser aplicados em projetos que contemplem comunidades de baixa renda. 
Uma nova Lei foi aprovada em março de 2007, sob o número 11.465, alterando novamente os percentuais de aplicação dos recursos. Esta Lei retomou os percentuais utilizados anteriormente, voltando à distribuição de $0,5 \%$ da $\mathrm{ROL}$ tanto para eficiência energética como para P\&D até o dia 31/12/2010.

O retorno dos percentuais mínimos obrigatórios de investimento definido pela Lei 11.465 (aumentando o percentual aplicado em eficiência energética de 0,25\% para $0,5 \%$ da ROL) reflete a dificuldade do mercado em obter recursos para financiar projetos de eficiência energética. Diferente do objetivo do legislador, expresso na Lei 9.991 de 2.000, este período de cinco anos, entre 2000 a 2005, não foi suficiente para o amadurecimento deste segmento do mercado.

Os projetos de P\&D possuem outra fonte de investimento, oriundo das geradoras e transmissoras, que também possuem a obrigação de investir $1 \%$ de sua ROL exclusivamente nestes projetos, portanto a alteração promovida pela Lei 11.465 não deve promover grande prejuízo aos setores ligados aos projetos de P\&D por disporem de outras fontes de recurso e por outro lado os setores do mercado ligados aos projetos de eficiência energética recebem com esta Lei um grande apoio ao seu desenvolvimento.

\section{3 - Tipos de projetos de eficiência energética}

Entende-se por eficiência energética o conjunto de práticas e ações que visa reduzir o consumo de um determinado tipo de energia, sem redução da produção ou prestação de serviço do sistema ou empresa que está consumindo esta energia.

A eficiência energética pode ser desenvolvida com um mesmo energético, como no caso da substituição de uma lâmpada convencional por outra mais econômica, que reduz o consumo de energia elétrica, ou com energéticos diferentes como no caso da substituição de um forno elétrico por um forno a gás, onde o consumo de energia equivalente é reduzido com a obtenção da mesma potência térmica do forno.

Os projetos de eficiência energética são caracterizados basicamente pelo tipo do uso final da energia. Eventualmente, projetos também podem contemplar mais do que um único uso final, entretanto, para se chegar à conclusão de quais são os usos finais que apresentam potencial de economia, a fim de se realizar o projeto de 
eficiência energética, é necessário primeiramente que seja feito um trabalho de diagnóstico energético na instalação.

Com base no diagnóstico energético é possível identificar detalhadamente como está sendo consumida a energia na instalação e quais são os potenciais de economia existentes. Os usos finais de energia elétrica mais comuns são:

- lluminação;

- Climatização ambiental;

- Força motriz;

- Aquecimento de água;

O uso final de aquecimento de água tem sua maior aplicação no varejo do setor residencial destinado ao aquecimento de água para banho, que não é o foco deste trabalho, por este motivo serão analisados nos próximos itens com mais profundidade os usos finais de energia elétrica iluminação, climatização ambiental e força motriz.

\subsection{1 - Projeto de iluminação}

Os projetos de eficiência energética em sistemas de iluminação em geral consistem na substituição das lâmpadas, reatores e luminárias antigas e ineficientes por outros mais eficientes, produzindo o mesmo nível de iluminância no ambiente.

A substituição da luminária convencional por outra mais eficiente faz com que a luminosidade que a lâmpada emite para cima seja refletida para baixo, aumentando o nível de iluminância no plano de trabalho. Desta forma, a potência da lâmpada, e eventualmente a quantidade de lâmpadas, poderá ser reduzida.

Comumente as luminárias antigas que são retiradas possuem baixa eficiência, permitindo que a luz seja projetada para todas as direções. Com a substituição pela luminária eficiente a luz é direcionada para o plano de trabalho, contudo podem ocorrer regiões com sombras entre luminárias devido a este direcionamento.

Para evitar este e outros problemas no sistema de iluminação, o trabalho de substituição de luminárias deve ser precedido de um projeto luminotécnico, que 
deverá avaliar as condições do local, medir o nível de iluminância e dimensionar a nova quantidade de lâmpadas e luminárias que deverão ser empregadas e, se for o caso, alterar a disposição das mesmas no ambiente, para que o nível de iluminância se mantenha uniforme e com a intensidade adequada.

Além da luminária também é possível obter ganho energético com a análise da relação entre o fluxo luminoso e a potência de uma lâmpada, dada em lumens/watt. Quanto maior a quantidade de lumens/watt mais eficiente é a lâmpada e, consequentemente, menos energia elétrica será gasta para se obter a iluminação adequada do ambiente. A figura 1 apresenta a relação lumens/watt de diversos tipos de lâmpadas.

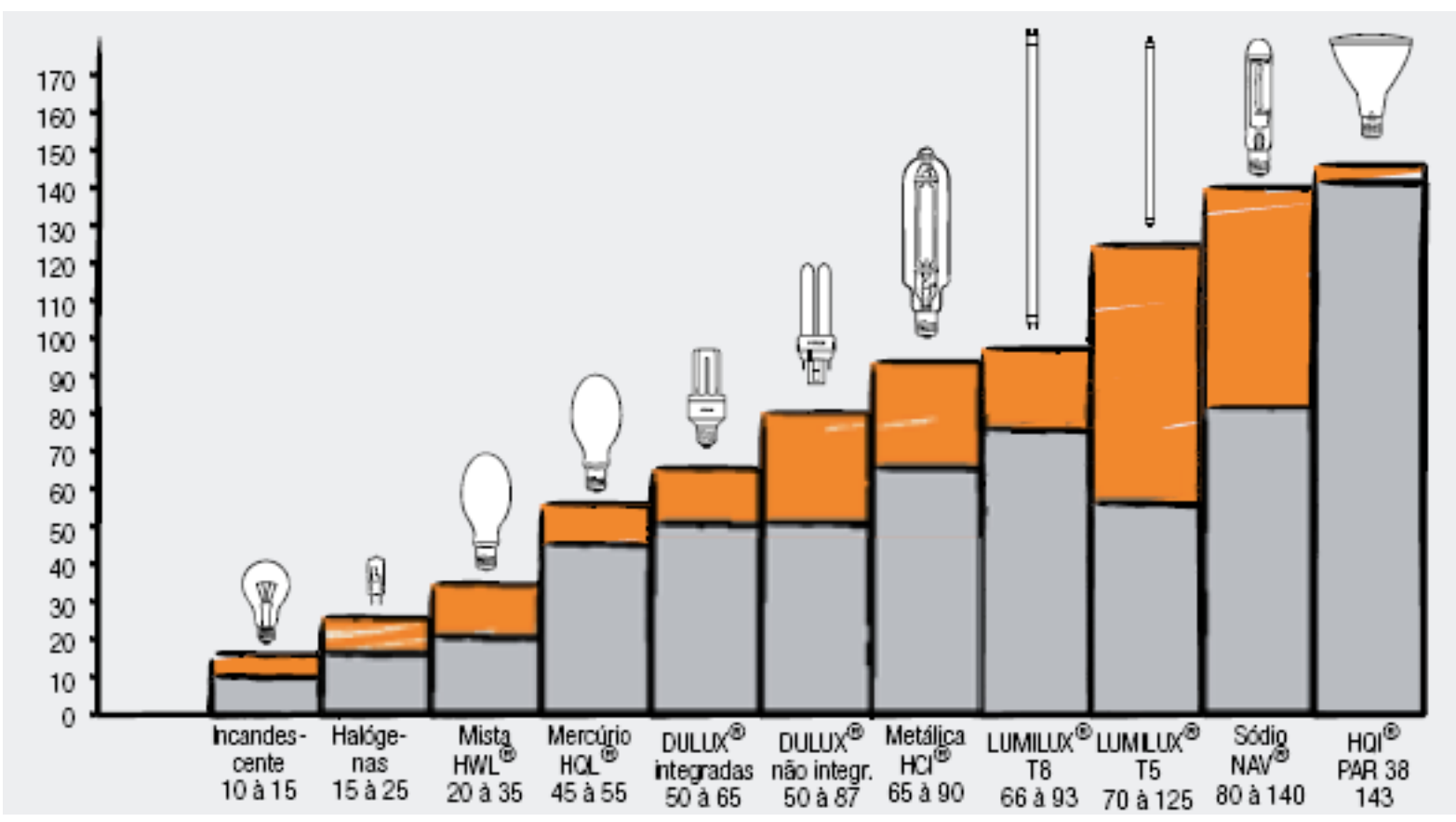

Figura 1 - Eficiência luminosa de lâmpadas Fonte: OSRAM [200-?]

Também é possível obter um ganho energético significativo com o emprego de reatores eletrônicos, que apresentam perdas muito baixas em relação aos convencionais reatores de núcleo ferromagnético. Enquanto um reator convencional para duas lâmpadas fluorescentes de $40 \mathrm{~W}$ apresenta perda de aproximadamente $20 \mathrm{~W}$, um reator eletrônico para duas lâmpadas fluorescentes de $32 \mathrm{~W}$ (equivalente em fluxo luminoso as lâmpadas de $40 \mathrm{~W}$ ), apresenta perda de aproximadamente 1 W. 


\subsection{2 - Projeto de climatização ambiental}

Os projetos de eficiência energética em sistemas de climatização ambiental em geral demandam altos volumes de investimentos com retorno em longo prazo. Esse tipo de projeto se torna viável principalmente em sistemas antigos, que estejam superdimensionados e que utilizem equipamentos ineficientes apresentando grande potencial de economia.

Primeiramente, é necessário fazer um levantamento detalhado da carga térmica de todos os ambientes climatizados e depois comparar com a capacidade do sistema de refrigeração. Se for identificado um excesso de capacidade dos equipamentos instalados em relação à carga térmica calculada, será possível obter um ganho na otimização da potência do novo sistema de climatização.

No levantamento da carga térmica é possível identificar perdas de carga por meio de falta de isolação térmica de dutos e também regiões com troca de ar de um ambiente condicionado para outro sem condicionamento. Ambos os problemas devem se transformar em medidas de correção a fim de reduzir a atual demanda de carga térmica.

Em instalações antigas os chillers ${ }^{1}$ da central de água gelada geralmente possuem uma relação ${ }^{2}$ de $\mathrm{kW} / \mathrm{TR}$ próximo a 1 . O projeto de eficiência energética pode substituir esse chiller por outro de mesma capacidade de refrigeração, porém com uma relação de $\mathrm{kW} / \mathrm{TR}$ menor, podendo chegar a valores da ordem de 0,33 , de acordo com o Catálogo Técnico da Carrier (2007?, p.4), fazendo com que seja consumida menos energia para produzir a mesma tonelada de refrigeração.

Além da substituição de chillers também é possível substituir os motores das bombas de água gelada e das bombas de água de condensação, se os mesmos apresentarem baixa eficiência. Caso o novo sistema possua uma capacidade de refrigeração diferente do sistema original, possivelmente as torres de resfriamento também deverão ser substituídas, ou poderão ser substituídos somente os seus

\footnotetext{
${ }^{1}$ Chillers são compressores com a função de aumentar a pressão do fluido refrigerante forçando-o a circular pelo circuito de refrigeração.

${ }^{2} \mathrm{~kW} / \mathrm{TR}$ é a relação entre a potência elétrica de um chiller, dada em kW, e a sua capacidade de refrigeração dada em Tonelada de Refrigeração - TR, sendo que uma TR representa a quantidade de calor necessário para derreter uma tonelada de gelo em 24 horas. A relação kW/TR é comumente utilizada para representar a eficiência de um chiller.
} 
motores, caso os antigos possuam uma baixa eficiência.

Sistemas antigos de climatização também podem ser desprovidos de um sistema de automação capaz de controlar, por exemplo, quantos compressores dos chillers precisam permanecer ligados simultaneamente. Se existir mais de um chiller na central de água gelada, o sistema de automação avalia a necessidade de todos permanecerem ligados constantemente ou se é possível desligar algum chiller em determinado período. A simples instalação de um sistema de automação é capaz de realizar diversos controles, otimizando o consumo de energia sem a necessidade de substituir nenhum equipamento.

Projetos que tenham o objetivo de retirar demanda no horário de ponta ${ }^{3}$ podem instalar bancos de gelo, que têm a função de armazenar energia térmica em forma de gelo no horário fora de ponta ${ }^{4}$ para produzir frio no horário da ponta somente com o gelo armazenado, dispensando a necessidade de ligar o chiller neste horário.

Também é possível a obtenção de um ganho adicional no que se refere ao aspecto ecológico. Sistemas de refrigeração antigos, em geral, operam com gás refrigerante que agride a atmosfera e o projeto de eficiência energética pode promover a substituição deste gás por outro considerado ecológico, providenciando o destinamento correto do gás retirado.

\subsection{3 - Projeto de força motriz}

Em setembro de 2001 foi publicada a Lei 10.295 que dispõe sobre a política nacional de conservação e uso racional de energia. A regulamentação desta Lei veio com a publicação do decreto 4.508 em dezembro de 2002 que definiu os níveis mínimos de eficiência energética de motores elétricos trifásicos de indução, tanto para os motores considerados padrão como para os motores de alto rendimento.

\footnotetext{
${ }^{3}$ Horário de ponta é o período definido pela concessionária e composto por três horas diárias consecutivas, exceção feita aos sábados, domingos e feriados nacionais, considerando as características do seu sistema elétrico. Neste período o valor da tarifa de energia é mais cara. Ex. No caso da AES-Eletropaulo o horário de ponta corresponde ao período entre 17:30h e 20:30h.

${ }^{4}$ Horário fora de ponta é o período composto pelo conjunto das horas diárias consecutivas e complementares àquelas definidas no horário de ponta. Neste período o valor da tarifa de energia é mais barata do que no horário de ponta.
} 
31

A figura 2 apresenta a tabela existente no referido decreto onde os rendimentos mínimos são apresentados para cada potência de motor, de acordo com o número de pólos e em função do tipo do motor, padrão ou de alto rendimento.

Motores antigos podem apresentar baixa eficiência e a sua substituição por motores de alto rendimento promove um ganho energético, produzindo a mesma potência na ponta do eixo. Em instalações em que o motor opera poucas horas por dia o retorno do investimento para substituir um motor por outro de maior rendimento geralmente se torna muito longo, o que pode inviabilizar o projeto.

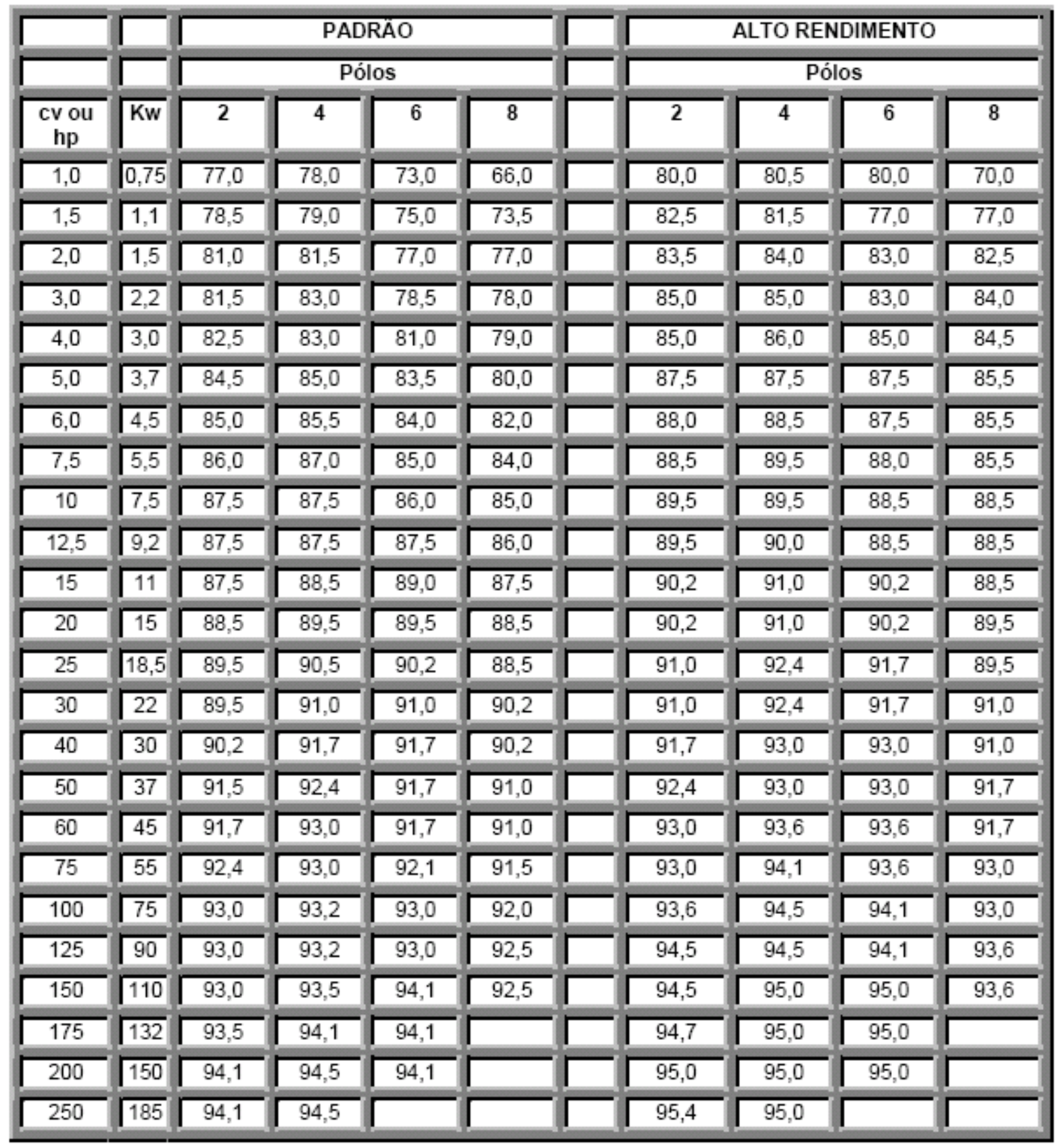

Figura 2 - Níveis mínimos de rendimento nominal de motores elétricos trifásicos de indução Fonte: BRASIL, 2002 
Além da substituição do motor por outro de mesma potência e de alto rendimento é importante analisar também qual é o carregamento do motor que está em operação. Pode ocorrer de um determinado motor estar superdimensionado para a carga mecânica que aciona, o que além de aumentar o consumo de energia elétrica ainda contribui para um baixo fator de potência.

O projeto de eficiência energética deve levantar a carga que está sendo requerida e especificar um motor que opere em uma faixa de melhor rendimento, o que gera uma economia de energia adicional na substituição do motor. 


\section{3 - PROTOCOLO DE QUIOTO}

$\mathrm{Na}$ década de 70 os cientistas que isoladamente anunciavam a correlação entre as ações do homem e as mudanças climáticas, começaram a sensibilizar pessoas e organizações em todo o mundo a tomar ações mitigatórias para conter este fenômeno.

Em 1972 na Suécia ocorreu a primeira convenção internacional sobre o meio ambiente conhecida como "Conferência de Estocolmo". Em 1979 aconteceu a primeira conferência mundial sobre o clima, evento em que se reconheceu que a mudança climática é um problema grave e de interesse global.

O Programa das Nações Unidas para o Meio Ambiente - Pnuma e a Organização Meteorológica Mundial - OMM criaram em 1988 o Intergovernmental Pannel on Climate Change - IPCC, apresentado na Conference on the Changing Atmosphere em Toronto. Logo depois em 1990 ocorreu em Sundsvall na Suécia o IPCC's First Assessment Report e dois anos depois ocorreu a ECO-92 no Rio de Janeiro, onde foi criada a "Convenção Quadro das Nações Unidas sobre a Mudança do Clima".

A partir desta época, anualmente, os países integrantes da convenção tem se reunido em encontros denominados Conferência das Partes - COP, ocorridos nas seguintes datas e locais:

- 1995: COP1 - Berlim / Alemanha

- 1996: COP2 - Genebra / Suíça

- 1997: COP3 - Quioto / Japão

- 1998: COP4 - Buenos Aires / Argentina

- 1999: COP5 - Bonn / Alemanha

- 2000: COP6 - Haia / Países Baixos

- 2001: COP6.b - Bonn / Alemanha

- 2001: COP7 - Marrakesh / Marrocos

- 2002: COP8 - Nova Déli / Índia

- 2003: COP9 - Milão / Itália

- 2004: COP10 - Buenos Aires / Argentina

- 2005: COP11 - Montreal / Canadá

- 2006: COP12 - Nairóbi / Quênia 
- 2007: COP13 - Bali / Indonésia

- 2008: COP14 - Poznan/Polônia

Uma das conferências de maior repercussão ocorreu em 1997, na qual se produziu o conhecido Protocolo de Quioto, determinando que no período entre 2008 e 2012 os países desenvolvidos deveriam reduzir as emissões de GEE em $5,2 \%$ em relação aos níveis de 1990. Estes gases estão relacionados no Anexo A do Protoloco conforme segue abaixo:

- Dióxido de Carbono $\left(\mathrm{CO}_{2}\right)$;

- Metano $\left(\mathrm{CH}_{4}\right)$;

- Óxido Nitroso $\left(\mathrm{N}_{2} \mathrm{O}\right)$;

- Hidrofluorcarbonos (HFCs);

- Perfluorcabonos (PFCs);

- Hexafluoreto de enxofre $\left(\mathrm{SF}_{6}\right)$.

Segundo Goldemberg (2003, p. 92) dentre todos GEE o $\mathrm{CO}_{2}$ possui uma participação de $60 \%$ no aquecimento global. Goldemberg (2003, p. 94) também afirma que $57 \%$ de todo $\mathrm{CO}_{2}$ emitido no mundo tem a sua origem na geração de energia.

A energia elétrica pode ser gerada a partir de diversas fontes. Dentre todos os modos possíveis de geração as fontes mais poluidoras são carvão, petróleo, madeira e gás natural, conforme apresentado por Grimoni et al. (2004, p. 57).

Dióxido de carbono

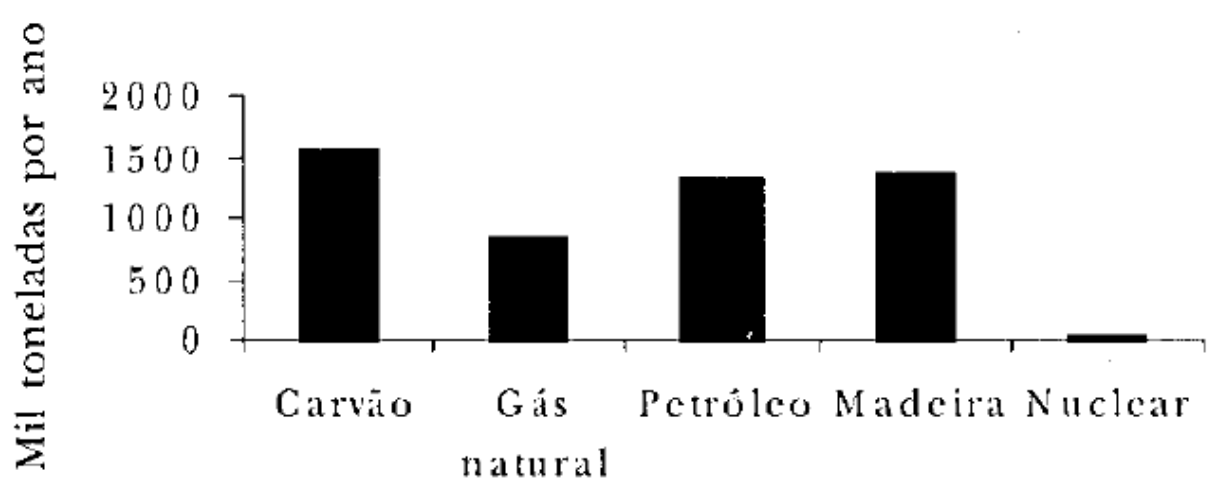

Figura 3 - Emissões anuais de $\mathrm{CO}_{2}$ para cada GW de eletricidade gerado por tipo de fonte Fonte: GRIMONI et al. (2004, p. 57). 
É notório que existem formas de gerar energia elétrica com um impacto muito menor ao meio ambiente em relação ao apresentado na figura 3, como por exemplo, através da energia eólica ou energia solar fotovoltaica, porém estas tecnologias ainda não estão disponíveis a um custo competitivo e na escala que o mundo necessita para abastecer a sua demanda.

Dentro deste cenário a eficiência energética possui um papel muito importante em reduzir a necessidade de ampliação da capacidade de geração de energia elétrica, mitigando assim os impactos ao meio ambiente.

O Anexo B do Protocolo de Quioto relaciona os países desenvolvidos incluídos no protocolo, bem como seus respectivos compromissos de redução percentual de emissão dos gases causadores do efeito estufa

Essa meta foi atribuída exclusivamente aos países desenvolvidos, com a visão de que se hoje eles apresentam um elevado grau de desenvolvimento é porque no passado foram realizadas grandes explorações dos recursos naturais, portanto estes países possuem uma parcela maior de responsabilidade da atual situação climática do planeta.

Os países em desenvolvimento foram poupados porque ainda precisam se desenvolver, o que naturalmente faz com que o consumo de energia cresça proporcionalmente mais do que nos países já desenvolvidos. Como a geração de energia elétrica é um dos maiores poluidores do meio ambiente, a inclusão desses países no Protocolo de Quioto estrangularia o seu crescimento, dificultando o seu desenvolvimento.

Entretanto, para que esses países possam se desenvolver de modo sustentável, incentivando-os a também reduzir as suas emissões de GEE, o Protocolo de Quioto inseriu dentro dos seus mecanismos de flexibilização, o conceito do Mecanismo de Desenvolvimento Limpo - MDL.

\section{1 - Mecanismo de desenvolvimento limpo - MDL}

O Protocolo de Quioto, apresenta três mecanismos de flexibilização chamados de Implementação Conjunta de Projetos - IC, Comércio de Emissões - EC e o Mecanismo de Desenvolvimento Limpo - MDL. Os dois primeiros mecanismos são 
aplicáveis exclusivamente aos países que fazem parte do Protocolo de Quioto, já o MDL é aplicado exclusivamente aos países em desenvolvimento que não fazem parte do Protocolo de Quioto.

Através desse mecanismo um projeto que reduza a emissão de GEE realizado em um país em desenvolvimento, pode gerar uma Redução Certificada de Emissão RCE, que é passível de comercialização no mercado mundial, podendo ser adquirido por um país que possui uma meta de redução de emissões, creditando-se dessa redução, para fins de contabilização.

Esse mecanismo gera uma receita para o país que realizou o projeto, incentivando que mais projetos dessa natureza sejam realizados, caminhando assim para o objetivo do Protocolo de Quioto, que é a obtenção do desenvolvimento sustentável e redução de emissão dos GEE no âmbito mundial.

3.1.1 - Apresentação de um projeto de MDL

Para que um projeto de MDL seja realizado, culminando na obtenção de RCEs, é necessário o cumprimento de sete etapas principais que determinam como o projeto deve ser conduzido.

1 - Elaboração do Documento de Concepção de Projeto - DCP

2 - Validação da Entidade Operacional Designada - EOD

3 - Aprovação pela Autoridade Nacional Designada - AND

4 - Registro no Conselho Executivo da United Nations Framework Convention on Climate Change - UNFCCC

5 - Monitoramento

6 - Verificação/Certificação

7 - Emissão das RCEs 


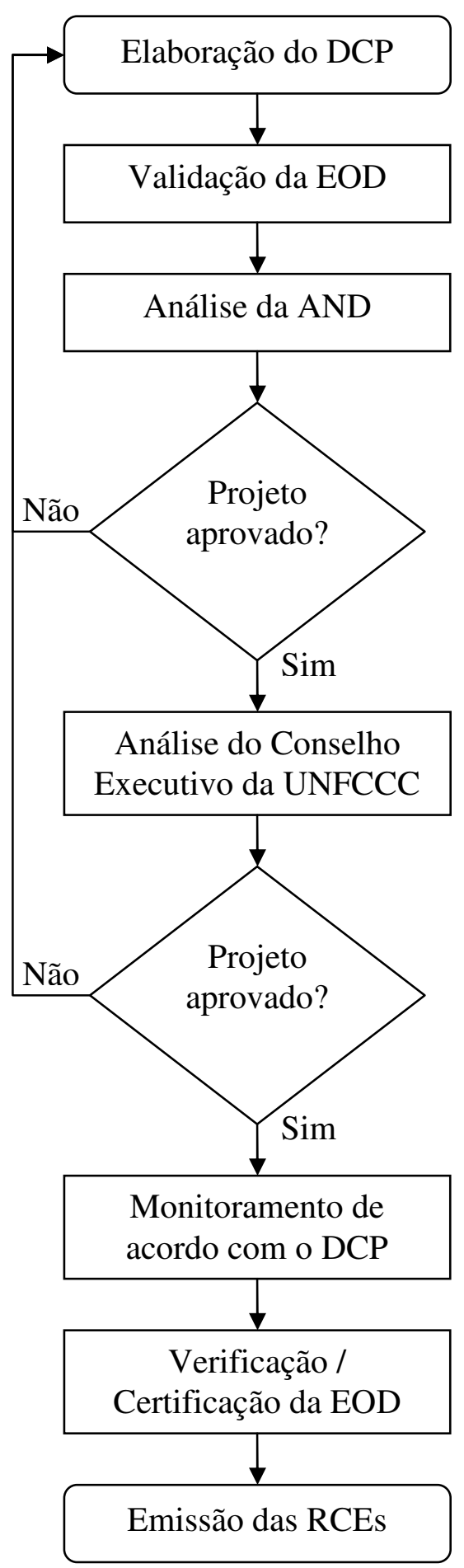

Figura 4 - Fluxograma de tramitação de um projeto de MDL Fonte: Elaboração própria

\section{Etapa 1 - Elaboração do Documento de Concepção de Projeto - DCP}

O projeto é iniciado com a elaboração do Documento de Concepção de Projeto DCP, que deve contemplar a descrição das atividades bem como os participantes envolvidos, também conhecidos como atores. O DCP ainda deve descrever 
detalhadamente a metodologia para determinar os valores de referência, também denominado de linha de base, e o respectivo cálculo da redução de emissões de GEE.

Complementarmente, o DCP deve estabelecer os limites do projeto, o plano de monitoramento, o período de obtenção do crédito, a justificativa para a adicionalidade, um relatório dos impactos ambientais, comentários das partes interessadas e detalhamento da fonte de financiamento.

A linha de base quantifica as emissões antrópicas ${ }^{5}$ de GEE que ocorreriam caso o projeto de MDL não fosse realizado. Essa quantificação é utilizada para verificar se o projeto efetivamente reduz emissões de forma adicional em relação ao que ocorreria na ausência do projeto (princípio da adicionalidade).

\section{Etapa 2 - Validação da Entidade Operacional Designada - EOD}

O DCP deve ser entregue a uma Entidade Operacional Designada - EOD que avalia a sua conformidade em relação aos requisitos do Protocolo de Quioto, destacando os seguintes pontos:

- Atividade voluntária;

- Aprovação no país de origem;

- Benefícios reais e mensuráveis;

- Princípio da adicionalidade;

- Inclusão dos comentários das partes interessadas;

- Adequação da análise do impacto ambiental à legislação nacional;

- Consideração de fuga (emissões de GEE fora dos limites do projeto);

- Uso de metodologia adequada para calcular a linha de base;

- Definição correta do período de obtenção dos créditos;

- Contribuição com o desenvolvimento sustentável do país;

O site http://cdm.unfccc.int/DOE/list/index.html acessado em 15/11/08 apresenta as EODs acreditadas pela UNFCCC para avaliar a conformidade de projetos de MDL.

\footnotetext{
${ }^{5}$ Emissões antrópicas são as emissões de GEE ocorridas pela intervenção do homem.
} 


\section{Etapa 3 - Aprovação pela Autoridade Nacional Designada - AND}

No Brasil a Autoridade Nacional Designada - AND é a Comissão Interministerial de Mudança Global do Clima do Ministério de Minas e Energia, que avalia o relatório de validação recebido da EOD, bem como a contribuição do projeto para o desenvolvimento sustentável do país, com base em cinco critérios:

- Distribuição de renda;

- Sustentabilidade ambiental local;

- Desenvolvimento das condições de trabalho e geração de empregos;

- Capacitação e desenvolvimento tecnológico;

- Integração regional;

\section{Etapa 4 - Registro no conselho executivo}

Depois de aprovado pela AND o projeto é apresentado ao Conselho Executivo da UNFCCC que avaliará a metodologia escolhida e a adicionalidade do projeto, dentre outros aspectos de conformidade.

Caso o Conselho Executivo da UNFCCC identifique alguma não-conformidade, pode ser solicitada uma revisão do relatório da EOD, entretanto, se o projeto estiver em conformidade com todos os requisitos ele receberá o registro.

\section{Etapa 5 - Monitoramento}

O monitoramento deve ser realizado de acordo com os critérios estabelecidos no DCP. Deverão ser recolhidos todos os dados, parâmetros e registros necessários com o intuito de calcular a redução de emissões de GEE em relação aos valores da linha de base.

\section{Etapa 6 - Verificação/Certificação}

A sexta etapa consiste na realização de auditorias periódicas pela EOD que verificará se as reduções de emissões de GEE estão ocorrendo conforme previsto 
no DCP dentro do período determinado. Esta auditoria compreende inspeções em campo, entrevista com participantes do projeto, coleta de dados, medições, observação de tarefas e quando necessário teste de equipamentos.

Com base na auditoria realizada, a EOD emite um certificado assegurando que a metodologia prevista foi empregada, que a documentação está completa, que as reduções de emissões foram obtidas e informa aos participantes do projeto se é necessária alguma alteração ou modificação na sua continuidade. Esse certificado é enviado para as partes envolvidas e para o Conselho Executivo da UNFCCC.

\section{Etapa 7 -Emissão das RCEs}

Com base no relatório de auditoria da EOD o Conselho Executivo da UNFCCC emite a quantidade de RCEs obtidas pelo projeto de MDL que foram consideradas mensuráveis e de longo prazo.

As RCEs são creditadas aos participantes do projeto na proporção por eles definida, já deduzida a parcela equivalente a $2 \%$ do total, que é contingenciado pela UNFCCC para um fundo destinado a ajudar os países mais vulneráveis a se adaptarem aos efeitos adversos da mudança do clima.

\subsection{2 - Projetos de MDL do Brasil}

O Brasil é o terceiro país em desenvolvimento que mais possui projetos de MDL. De acordo com o relatório do Ministério da Ciência e Tecnologia do dia 30 de setembro de 2008 o Brasil possui 318 projetos que correspondem a $8 \%$ dos projetos mundiais conforme figura 5 . 


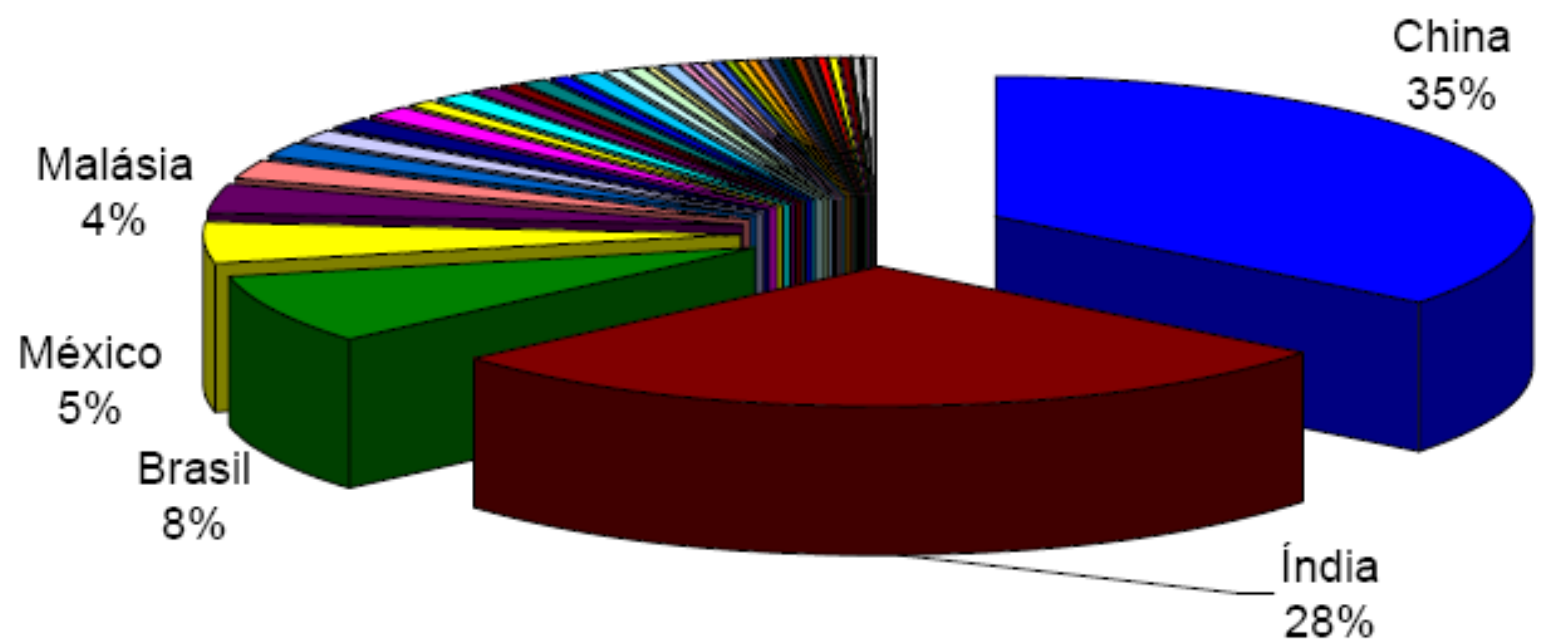

Figura 5 - Percentual por pais das atividades de projetos de MDL no mundo Fonte: MINISTÉRIO DA CIÊNCIA E TECNOLOGIA - MCT, 2008a

Dentre os 318 projetos brasileiros destacam-se os projetos relativos à geração de energia por fonte renovável, representando quase metade do total. Os projetos de eficiência energética possuem uma participação modesta com apenas 21 projetos, de acordo com a figura 6 .

\begin{tabular}{|c|c|c|c|c|c|c|}
\hline Projetos em Validaçäo/Aprovação & $\begin{array}{c}\text { Número de } \\
\text { projetos }\end{array}$ & $\begin{array}{c}\text { Redução } \\
\text { anual de } \\
\text { emissäo }\end{array}$ & $\begin{array}{c}\text { Redução de } \\
\text { emissão no } \\
\mathbf{1}^{\circ} \text { periodo de } \\
\text { obtençäo de } \\
\text { crédito }\end{array}$ & $\begin{array}{c}\text { Número } \\
\text { de } \\
\text { projetos }\end{array}$ & $\begin{array}{c}\text { Redução } \\
\text { anual de } \\
\text { emissäo } \\
\text { emissäo no } \\
\mathbf{1}^{\circ} \text { período } \\
\text { de } \\
\text { obtenção } \\
\text { de crédito }\end{array}$ \\
\hline Energia renovável & 150 & $16,431,099$ & $115,440,422$ & $47 \%$ & $39 \%$ & $36 \%$ \\
\hline Suinocultura & 55 & $2,737,322$ & $25,667,400$ & $17 \%$ & $6 \%$ & $8 \%$ \\
\hline Aterro Sanitário & 29 & $10,036,702$ & $73,855,179$ & $9 \%$ & $24 \%$ & $23 \%$ \\
\hline Processos industriais & 7 & 832,946 & $6,131,592$ & $2 \%$ & $2 \%$ & $2 \%$ \\
\hline Eficiência Energética & 21 & $1,490,288$ & $14,535,192$ & $7 \%$ & $4 \%$ & $5 \%$ \\
\hline Resíduos & 10 & $1,160,797$ & $9,360,545$ & $3 \%$ & $3 \%$ & $3 \%$ \\
\hline Redução de N2O & 5 & $6,373,896$ & $44,617,272$ & $2 \%$ & $15 \%$ & $14 \%$ \\
\hline Eroca de combustivel fóssil & 39 & $2,907,977$ & $24,284,745$ & $12 \%$ & $7 \%$ & $8 \%$ \\
\hline Reflores fugitivas & 1 & 34,685 & 242,795 & $0 \%$ & $0 \%$ & $0 \%$ \\
\hline
\end{tabular}

Figura 6 - Distribuição das atividades de projeto de MDL no Brasil por tipo Fonte: MINISTÉRIO DA CIÊNCIA E TECNOLOGIA - MCT, 2008a

Observa-se que as 3 últimas colunas da figura 6 apresentam o cálculo percentual de número de projetos e de redução de emissão, onde entende-se que nos indicadores que apresentam $0 \%$ para as emissões fugitivas e para o reflorestamento, existe um valor percentual associado, entretanto este valor é inferior a $1 \%$.

Apesar dos 21 projetos de eficiência energética apresentados no relatório, apenas oito são encontrados no site do Ministério da Ciência e Tecnologia acessado em 01/11/08, sendo todos eles do Grupo Pão de Açúcar. Estes oito projetos possuem 
praticamente as mesmas ações de eficiência energética, porém cada um abrange prédios diferentes do Grupo Pão de Açúcar. Os demais 13 projetos de eficiência energética, que estão contabilizados nesta rubrica, possivelmente são projetos pelo lado da oferta, que melhoram a eficiência de sistemas de geração de energia elétrica.

Face ao exposto, é possível observar que o Brasil se apresenta de forma destacada no mercado mundial de projetos de MDL, e que praticamente metade dos projetos nacionais são relativos à geração de energia elétrica por fonte renovável.

Considerando que os oito projetos existentes de eficiência energética pelo lado da demanda são oriundos de uma mesma instituição, pode-se dizer que há um único projeto de MDL no Brasil a partir de eficiência energética aplicado no uso final da energia elétrica.

O estudo realizado no capítulo 5 deste trabalho analisa a viabilidade da realização de um projeto de MDL concomitante ao projeto de eficiência energética, o resultado deste estudo pode sinalizar o por que da existência de um número tão pequeno destes projetos no cenário atual. 


\section{4 - OBTENÇÕES DE CRÉDITOS DE CARBONO COM PROJETOS DE EFICIÊNCIA ENERGÉTICA}

A redução do consumo de energia elétrica não implica em uma redução direta na emissão de GEE, mas promove uma redução indireta devido aos gases que deixam de ser emitidos pela energia que não precisa ser gerada.

Entretanto, nem todos os projetos de eficiência energética são passíveis de obtenção de créditos de carbono, devido às regras e pré-requisitos que precisam ser atendidos, conforme será mostrado nos itens a seguir.

\section{1 - Critérios de elegibilidade de projetos de MDL}

Todo projeto de MDL necessita atender alguns requisitos, que devem ser certificados pela EOD, conforme estabelece o parágrafo 5 do Artigo 12 do Protocolo de Quinto:

5. As reduções de emissões resultantes de cada atividade de projeto devem ser certificadas por entidades operacionais a serem designadas pela Conferência das Partes na qualidade de reunião das partes deste Protocolo, com base em:

(a) Participação voluntária aprovada por cada parte envolvida;

(b) Benefícios reais, mensuráveis e de longo prazo relacionados com a mitigação da mudança do clima, e

(c) Reduções de emissões que sejam adicionais as que ocorreriam na ausência da atividade certificada de projeto. (UNITED NATIONS, [1998?], p. 15)

O primeiro critério de elegibilidade é a voluntariedade. Esse critério determina que para ser elegível o projeto deve ter sido concebido e desenvolvido por vontade própria do executor, e que a obtenção de créditos de carbono foi um motivador na decisão de realizar o projeto. Esta questão será analisada também no item 4.2.

Todo projeto deve ter benefícios reais e claramente identificados como advindos da sua realização. Esse segundo critério determina que os benefícios devam ser duradouros e comprovadamente contribuir para a mitigação da mudança climática. 
Adicionalmente é imprescindível que o projeto disponha de métodos concretos de medição que comprovem a redução efetiva de emissões, sem o emprego de questões subjetivas ou simplesmente comportamentais que, em geral, são de difícil comprovação.

O terceiro critério de elegibilidade refere-se à adicionalidade. Para certificar se o projeto está atendendo este critério, primeiramente, é preciso definir uma linha de base, onde são quantificadas as emissões atmosféricas de GEE que ocorreriam caso o projeto não fosse realizado, a partir deste valor deve ser definido quais serão os novos índices de emissão após a realização do projeto, sendo a diferença caracterizada como a redução de emissão alcançada.

É imprescindível que a realização do projeto resulte em uma emissão de GEE menor do que ocorreria caso o projeto não fosse realizado, sendo que esta diferença corresponderá à quantidade obtida de créditos de carbono, também chamado de RCE.

\title{
4.2 - Propriedade das RCEs
}

Durante a fase de concepção do projeto de eficiência energética é necessário definir quem será o proprietário das RCEs e, consequentemente, quem receberá a receita advinda de sua venda.

O Protocolo de Quioto não aborda claramente esta questão, entretanto, é possível extrair do artigo 12 algumas frases que orientam esta análise. O parágrafo 9 permite que entidades privadas e públicas participem do mecanismo de desenvolvimento limpo.

\begin{abstract}
A participação no mecanismo de desenvolvimento limpo, incluindo nas atividades mencionadas no parágrafo 3(a) acima e na aquisição de reduções certificadas de emissão, pode envolver entidades privadas e/ou públicas e deve sujeitar-se a qualquer orientação que possa ser dada pelo conselho executivo do mecanismo de desenvolvimento limpo. (UNITED NATIONS, [1998?], p. 15)
\end{abstract}

O parágrafo 3(a) menciona que "(a) As Partes não incluídas no Anexo I beneficiarse-ão de atividades de projetos que resultem em reduções certificadas de emissões" (UNITED NATIONS, [1998?], p. 14). 
Analisando os dois trechos do Protocolo de Quioto é possível concluir que qualquer entidade pública ou privada pode beneficiar-se das RCEs, desde que se sujeitem às orientações do Conselho Executivo da UNFCCC. O benefício extraído das RCEs é a receita advinda de sua venda, portanto qualquer entidade pública ou privada pode receber o dinheiro referente a esta transação.

O agente financiador é a entidade que provavelmente deve se beneficiar com a venda dos créditos de carbono, portanto para realizar esta análise é pertinente separar projetos realizados pelas distribuidoras de energia, com recurso do PEE, dos projetos realizados por meio de financiamento bancário ou com recursos das próprias Escos e até mesmo com recursos dos próprios consumidores de energia beneficiários dos projetos. A figura 7 apresenta as possibilidades de origem do financiamento dos projetos, associados aos possíveis beneficiários das RCEs, que serão discutidos nos próximos itens.

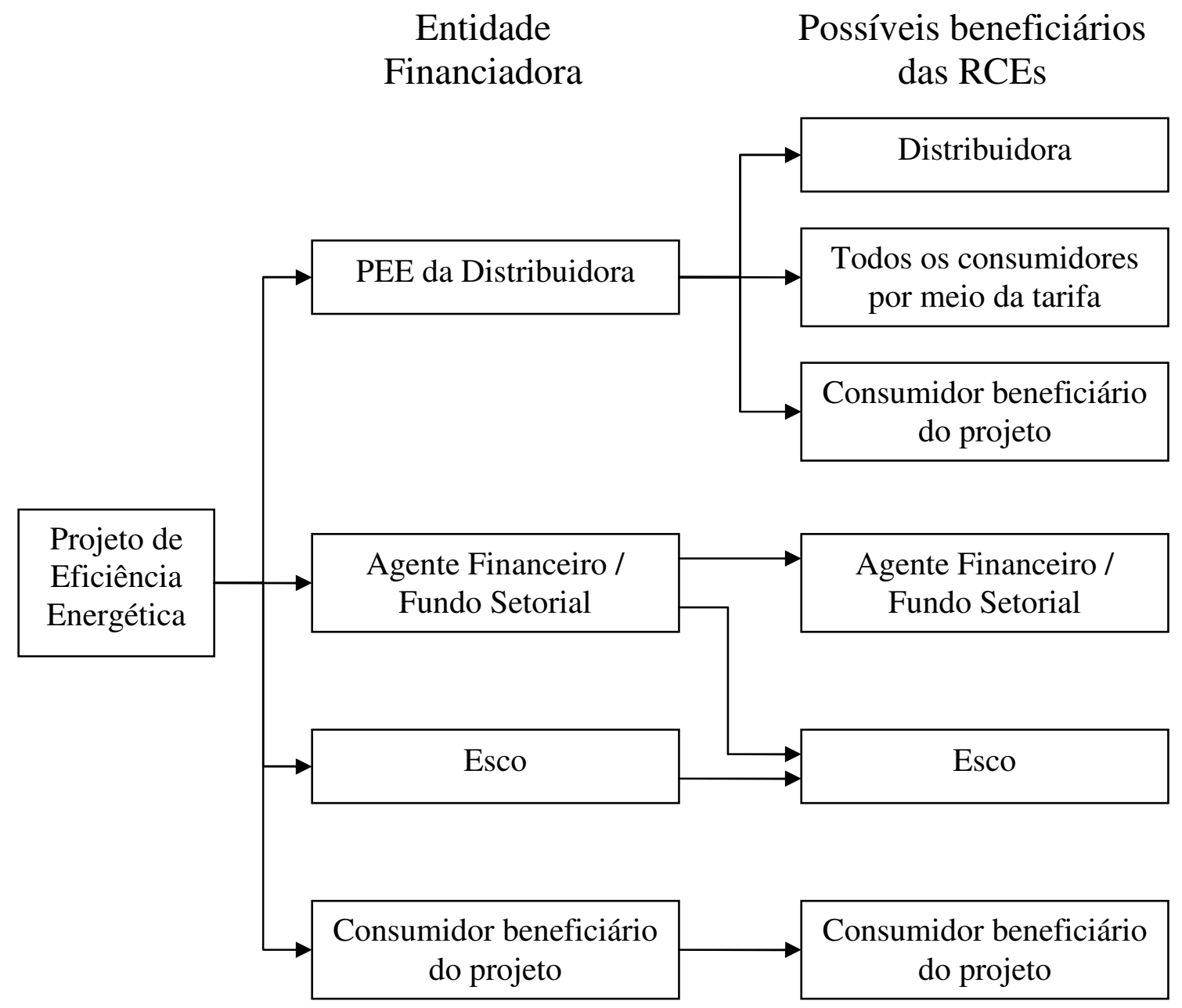

Figura 7 - Entidades financiadoras e possíveis beneficiários das RCEs de projetos de eficiência energética

Fonte: Elaboração própria 


\subsection{1 - Projetos financiados pelo PEE com as RCEs para as distribuidoras}

Faz-se necessário analisar o mérito do recebimento das RCEs, no caso dos projetos custeados pelo PEE, devido ao fato de que há uma Lei, de número 9.991, que determina a obrigatoriedade da execução de projetos de eficiência energética por parte das distribuidoras de energia elétrica, o que pode ser caracterizado como uma infração ao critério da voluntariedade, estudado no item 4.1.

A Lei 9.991 determina o percentual da ROL da distribuidora que deve ser aplicado no seu PEE, ou seja, é determinado o volume financeiro de recursos a serem aplicados, porém a referida Lei não determina a economia de energia a ser obtida.

A Resolução 300/08 da Aneel regulamenta a Lei 9.991 e aprova o Manual para Elaboração do Programa de Eficiência Energética - MPEE, que é um guia determinativo de procedimentos a serem seguidos pelas distribuidoras, no âmbito da realização dos seus projetos de eficiência energética.

O MPEE não determina qual é a economia de energia a ser obtida pelo PEE das distribuidoras, o seu único critério para aprovação de um projeto é o limite máximo da Relação Custo Benefício - RCB de 0,8. Esta relação é obtida dividindo o custo anualizado de implantação do projeto pelos seus benefícios também anualizados. Os benefícios mencionados neste cálculo são a redução de demanda no horário de ponta e a economia de energia. Como a economia de energia reduz o faturamento da distribuidora, qual é o motivador que ela possui para executar projetos que proporcionam elevada economia de energia?

As distribuidoras poderiam definir duas ações que atendem a regulamentação sem proporcionar grande redução no consumo de energia e consequentemente em seu faturamento, primeiro poderiam ser executados somente projetos com a RCB próxima ao limite de 0,8 , em detrimento de projetos com RCB menores que economizariam mais energia. Uma segunda possibilidade seria a realização de projetos que somente deslocam a demanda do horário de ponta para o horário fora de ponta, sem redução no consumo total de energia.

Caso as distribuidoras tenham o direito de realizar um projeto de MDL concomitante ao seu PEE, a receita advinda da venda das RCEs poderia ser o motivador para que ela busque projetos que promovam uma maior economia de energia, além nos critérios mínimos definidos na regulamentação vigente. 


\subsection{2 - Projetos financiados pelo PEE com as RCEs para os consumidores}

As RCEs recebidas de projetos financiados pelo PEE das distribuidoras podem ser revertidas aos consumidores basicamente de duas formas, direcionando este crédito ao consumidor beneficiário do projeto ou rateando para todos os consumidores que estão pagando suas contas de energia, e que, de certa forma, estão financiando a execução dos projetos.

Considerando que o recurso utilizado pela distribuidora para financiar o projeto foi extraído da tarifa paga pela sociedade, a receita advinda do emprego deste recurso poderia ser recebida pela distribuidora e utilizada para abater o valor da tarifa, beneficiando a todos os consumidores.

Também pode ser considerado que pelo fato de o recurso do PEE ser destinado à redução do consumo de energia elétrica, independente da busca pela obtenção dos créditos de carbono, o consumidor que estivesse recebendo o projeto poderia se beneficiar também com as RCEs.

A possibilidade de o consumidor beneficiário do projeto se creditar da receita advinda da venda das RCEs faria com que o recurso pago por todos, por meio da tarifa, beneficiasse poucos consumidores, que são escolhidos em um caráter discricionário pela distribuidora, o que poderia caracterizar uma falta de isonomia no tratamento entre os consumidores.

Em suma, se a receita obtida com a venda de RCEs, advinda da realização de projetos do PEE, não puder ser contabilizada pelas distribuidoras de energia elétrica, seria mais isonômico que esta receita fosse utilizada para abatimento do valor da tarifa, beneficiando toda a sociedade.

\subsection{3 - Projetos financiados por agente financeiro ou fundo setorial}

Os projetos de eficiência energética em geral são realizados por Escos e o seu financiamento pode ser feito por agentes financeiros ou fundos setoriais específicos. 
O objetivo de um agente financeiro, ou de um fundo que esteja financiado o projeto, é receber o pagamento do financiamento com o menor risco possível. O responsável por este pagamento é a empresa que está realizando o projeto, em geral uma Esco, por este motivo é ela quem deveria ficar com a receita advinda das RCEs.

Desta forma, os riscos ficam por conta da Esco e o agente financeiro fica protegido, por força contratual, quanto às variações de receita referente à venda das RCEs, que podem variar em função de alteração na quantidade de energia economizada pelo projeto e da oscilação do preço das RCEs no mercado.

Eventualmente, contratos bilaterais podem definir que o agente financiador se beneficie da venda das RCEs, entretanto, esta definição depende da negociação entre as partes.

\section{3 - Potencial de créditos de carbono}

Devido a um histórico de décadas de consumo de energia sem grande preocupação com a eficiência energética e devido ao fato de que em geral equipamentos ineficientes são mais baratos do que os eficientes, pode-se considerar que atualmente há um grande potencial de melhoria da eficiência energética em todos os segmentos de mercado.

Considerando que todas as novas cargas instaladas fossem eficientes, não haveria aumento neste potencial de economia, entretanto, não é este cenário que se anuncia. Como ainda existem muitos equipamentos ineficientes sendo comercializados e instalados, pode-se projetar potenciais de eficiência energética futuros baseados nas projeções de expansão de mercado feitas pelos órgãos competentes.

Desta forma, é possível quantificar o potencial brasileiro de geração de créditos de carbono a partir da realização de projetos de eficiência energética. Esta análise pode ser realizada tanto no atual mercado consumidor de energia elétrica quanto no mercado futuro, a partir das projeções de crescimento.

Antes de realizar o cálculo de obtenção de crédito de carbono é importante definir o fator de emissão, que será aplicado sobre a economia de energia, para 
quantificação da redução de emissão de GEE na geração da energia elétrica. $O$ próximo item deste trabalho analisa esta questão.

\subsection{1 - Fator de emissão}

O fator de emissão deve ser multiplicado pela energia economizada para se determinar o quanto essa redução de consumo se traduz em redução da emissão de GEE. A determinação deste fator é um aspecto muito importante e polêmico, pois ele pode viabilizar ou inviabilizar um projeto.

Como o Brasil possui uma matriz energética hidrotérmica a parte da energia elétrica gerada pelas hidroelétricas, que corresponde à maior parcela, é considerada limpa e a parte da energia elétrica gerada por termoelétricas possui um fator de emissão variável, de acordo com o tipo de fonte de combustível utilizado.

Uma primeira questão polêmica refere-se à inserção neste cálculo das emissões de metano e dióxido de carbono dos reservatórios das hidroelétricas, devido à decomposição da vegetação que foi submersa durante a formação do lago.

Existem estudos a respeito desta questão, entretanto, ainda não há um consenso do fator de emissão dos lagos a ser considerado. Atualmente esta emissão não é contabilizada, porém estudos apresentam que este fator pode ser tão elevado a ponto de superar a emissão de uma usina a carvão, como demonstra a tabela 1.

\begin{tabular}{lr}
\hline Fonte de Energia & $\begin{array}{r}\text { Fator de Emissão } \\
\text { tCO }\end{array}$ \\
\hline Carvão & $0,940-1,340$ \\
Óleo & $0,690-0,890$ \\
Gás Natural & $0,650-0,770$ \\
Energia Nuclear & $0,008-0,027$ \\
Solar Fotovoltaico & $0,081-0,260$ \\
Eólica & $0,016-0,120$ \\
Hidroelétrica & $0,004-0,018$ \\
Reservatórios brasileiros ${ }^{*}$ & $0,006-2,100$ \\
\hline${ }^{*}$ Valores de 9 reservatórios brasileiros de usinas \\
com potência entre 216 e 12.600 MW
\end{tabular}

Tabela 1 - Fator de emissão de $\mathrm{CO}_{2}$ de usina de energia elétrica por tipo de fonte Fonte: Elaboração própria adaptado de TREMBLAY, et al., 2005?, p. 3 
Outra dificuldade na quantificação do fator de emissão refere-se à operação das termoelétricas que possuem despacho variável, dependente da condição de armazenamento de água das hidroelétricas, portanto é necessário contabilizar a emissão das termoelétricas somente quando despachadas pelo Operador Nacional do Sistema - ONS.

Como essas variáveis se alternam diariamente é necessário acumular fatores de emissão de um determinado período de tempo, para se obter um valor que contemple a média anual de variação de chuvas e conseqüente operação das termoelétricas. O site do Ministério da Ciência e Tecnologia acessado em 01/11/08, http://www.mct.gov.br/index.php/content/view/72764.html, mantém disponível para consulta os fatores de emissão do Sistema Interligado Nacional de forma diária e a sua média anual.

Outra questão polêmica refere-se à utilização do fator de emissão do submercado onde a energia está sendo economizada ou do fator de emissão médio do país, uma vez que a maior parte da rede elétrica é interligada. No caso da aplicação do fator de emissão regional, projetos em regiões com predominância de usinas hidroelétricas teriam a sua viabilidade prejudicada, devido ao baixo fator de emissão, ao contrário de projetos realizados em regiões com usinas predominantemente térmicas, que teriam a viabilidade do projeto aumentada devido ao elevado fator de emissão.

Obviamente, foge a esta questão a situação na qual a redução de consumo de energia ocorra em uma região que seja atendida por um sistema isolado. Neste caso o fator de emissão a ser utilizado deve corresponder exclusivamente ao respectivo sistema de geração de energia elétrica.

O projeto de MDL realizado pelo Grupo Pão de Açúcar, mencionado no item 3.1.2, utiliza um fator de emissão de $0,2611 \quad \mathrm{tCO}_{2} / \mathrm{MWh}$ para 0 submercado sul/sudeste/centro-oeste calculado com base em dados dos anos de 2003, 2004 e 2005 utilizando a metodologia de cálculo das Nações Unidas AMS-II-E.

De acordo com o Centro de Gestão e Estudos Estratégicos (2008, p. 158), o fator de emissão para o submercado sul/sudeste/centro-este é de 0,279 $\mathrm{tCO}_{2} / \mathrm{MWh}$ utilizando 2005 como o ano base na metodologia ACM0002 das Nações Unidas.

O Governo Federal elaborou um Plano Nacional sobre Mudança do Clima que considera o fator de emissão, do Sistema Interligado Nacional na metodologia ACM0002, de 0,29 tCO $/$ MWh (BRASIL, 2008, p. 30) no ano base de 2008. 
Este trabalho utiliza o fator e emissão de $0,279 \mathrm{tCO}_{2} / \mathrm{MWh}$ para realização dos cálculos de análise de viabilidade.

\subsection{2 - Cenário atual do potencial de créditos de carbono}

Para estimar o atual potencial existente de economia de energia este trabalho utiliza os dados do Plano Nacional de Energia - PNE-2030, que considera estimativas da Associação Brasileira das Empresas de Conservação de Energia - Abesco e da Eletrobrás, totalizando um potencial de economia de 29,7 TWh, distribuídos em diversos segmentos conforme figura 8.

\begin{tabular}{|l|r|r|}
\hline \multicolumn{3}{|c|}{ ENERGIA ELÉTRICA } \\
\hline \multicolumn{1}{|c|}{ Setor } & Potencial \\
\hline Industrial $^{1}$ & 9,2 & R $\$$ milhões $^{3}$ \\
\hline Saneamento $^{1}$ & 1,5 & 778 \\
\hline Comercial $^{1}$ & 5,6 & 479 \\
\hline Residencial (10\%) $^{1}$ & 7,5 & 636 \\
\hline Público $^{1}$ & 1,6 & 134 \\
\hline Iluminação pública $^{2}$ & 1,3 & 112 \\
\hline Outros (10\%) $^{\text {TOTAL }}$ & $\mathbf{2 9 , 7}$ & $\mathbf{2 . 5 1 8}$ \\
\hline
\end{tabular}

1) Estimativa da Abesco

2) Estimativa Reluz/Eletrobrás

3) US\$33,93/MWh e 2,5 R $\$ /$ US\$

Figura 8 - Estimativa do potencial de economia de energia elétrica no Brasil Fonte: MINISTÉRIO DE MINAS E ENERGIA, 2007b

Aplicando o fator de emissão de 0,279 $\mathrm{tCO}_{2} / \mathrm{MWh}$, apresentado no item anterior, sobre os 29,7 TWh potenciais de redução de consumo, obtém-se um potencial teórico de redução de emissão de 8.286.300 toneladas de $\mathrm{CO}_{2}$.

Entretanto, deve-se ponderar se todo esse potencial de redução no consumo de energia elétrica se enquadra nos critérios de elegibilidade à obtenção de créditos de 
carbono. Se for considerado que todas as economias nestes segmentos são adicionais, podem ser medidas e são de realização voluntária, é possível a obtenção dos créditos de carbono.

\subsection{3 - Cenário futuro do potencial de créditos de carbono}

O Greenpeace publicou um estudo denominado Revolução Energética que apresenta um plano de ação para obter as reduções de $\mathrm{CO}_{2}$ necessárias ao Planeta assegurando o suprimento de energia e garantindo um desenvolvimento econômico sustentável. A seguir são apresentados os cinco princípios-chave deste plano de ação:

- Implementar sistemas de geração de energia elétrica descentralizados e renováveis;

- Respeitar os limites naturais do meio ambiente;

- Eliminar gradualmente fontes de energia elétrica poluidoras e não sustentáveis;

- Promover a equidade na utilização dos recursos;

- Desvincular o crescimento econômico do consumo de combustíveis fósseis;

A partir destes cinco princípios o estudo conclui que o Brasil pode eliminar as usinas a óleo diesel, a carvão e nuclear, bem como diminuir a participação das usinas a gás até o ano de 2050 , sendo que neste cenário $88 \%$ da energia elétrica gerada no país seria oriunda de fontes renováveis e 413 TWh (GREENPEACE 2007, p. 4) de energia elétrica poderia ser economizada através de ações de eficiência energética que reduzem a intensidade elétrica ${ }^{6}$ conforme apontado na figura 9.

O resultado deste estudo aponta que para se obter esta intensidade elétrica e consequentemente esta economia de energia é fundamental que os cinco princípios apontados neste item sejam cumpridos e implantados de forma rigorosa.

\footnotetext{
${ }^{6}$ Intensidade elétrica equivale à quantidade de energia elétrica necessária para produzir uma unidade de PIB. O estudo do Greenpeace apresenta a intensidade elétrica em TWh/milhões de R\$.
} 


\begin{tabular}{|c|c|c|c|c|c|c|}
\hline $\begin{array}{l}\text { Intensldade Elétrica } \\
\text { (TWh/milháo R\$) }\end{array}$ & 2005 & 2010 & 2020 & 2030 & 2040 & 2050 \\
\hline Cenárlo de Referencla & 297 & 392 & 494 & 521 & 567 & 558 \\
\hline $\begin{array}{l}\text { Cenárlo de Revolução } \\
\text { Energética }\end{array}$ & 297 & 356 & 447 & 446 & 440 & 391 \\
\hline
\end{tabular}

Figura 9 - Comparativo de intensidade elétrica prevista até 2050 entre cenário de referência e cenário de revolução energética

Fonte: GREENPEACE, 2007

Aplicando o potencial de economia de 413 TWh sobre o fator de emissão 0,279 $\mathrm{tCO}_{2} / \mathrm{MWh}$ obtém-se um potencial teórico de redução de emissão de 115.227 .000 toneladas de $\mathrm{CO}_{2}$ para 2050. 


\section{5 - INFLUÊNCIA DOS CRÉDITOS DE CARBONO NA VIABILIDADE FINANCEIRA}

O capítulo 4 mostrou que os projetos de eficiência energética são passíveis de obtenção de créditos de carbono, pelo fato de reduzirem indiretamente a emissão de GEE devido à energia que não precisa ser gerada.

Os créditos de carbono influenciam na viabilidade do projeto ao gerar uma receita adicional na sua venda, entretanto, é necessário ponderar até que ponto esta influência é positiva, devido ao fato de existirem custos adicionais necessários para realizar todo o processo de validação e certificação, apresentado no item 3.1.1, que pode prejudicar a viabilidade financeira do projeto.

\section{1 - Decisão sobre o momento de venda das RCEs}

O momento em que as RCEs serão vendidas é uma definição estratégica do projeto. Existem vários momentos em que esta transação pode ser realizada, impactando de maneira diferente sobre o desempenho financeiro.

Depois de concluído o projeto, devem ser realizados relatórios de medição a fim de certificar se efetivamente foram atingidas as reduções de emissão de GEE previstas, para que as RCEs possam ser emitidas. Após a emissão das RCEs, anualmente devem ser realizadas medições, com o objetivo de verificar exatamente a redução de emissão alcançada pelo projeto em cada período de medição, visando à apuração de variações normais que possam ocorrer. Sendo assim, a venda dos créditos pode ser realizada ao fim de cada período de medição e durante toda a vida do projeto, conforme apresentado na figura 10.

Este modo de venda dos créditos de carbono é considerado conservador, pois no momento da venda as RCEs já foram emitidas, mitigando qualquer risco que o projeto possa ter que o impeça de receber as RCEs, contemplando inclusive as possíveis variações de redução de emissão de GEE que possam ocorrer ao longo do projeto. 


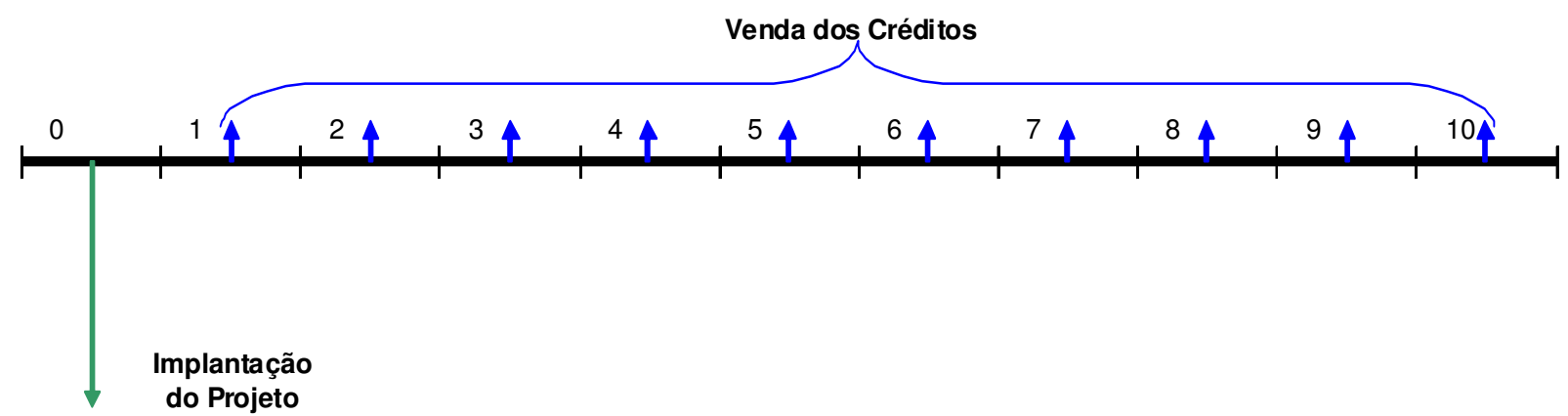

Figura 10 - Venda anual dos créditos de carbono

Fonte: Elaboração própria

Entretanto, há a possibilidade da venda do total de créditos, que serão acumulados por todo o período do projeto (um período de dez anos ou três períodos de sete anos), logo após a emissão por parte do Conselho Executivo da UNFCCC, conforme ilustrado na figura 11. Como a venda está sendo feita de forma antecipada, pode ser aplicado um deságio sobre o valor de mercado, e as variações de redução de emissão, que serão apuradas ao longo do período de operação do projeto, deverão ser ajustadas a cada período de medição.

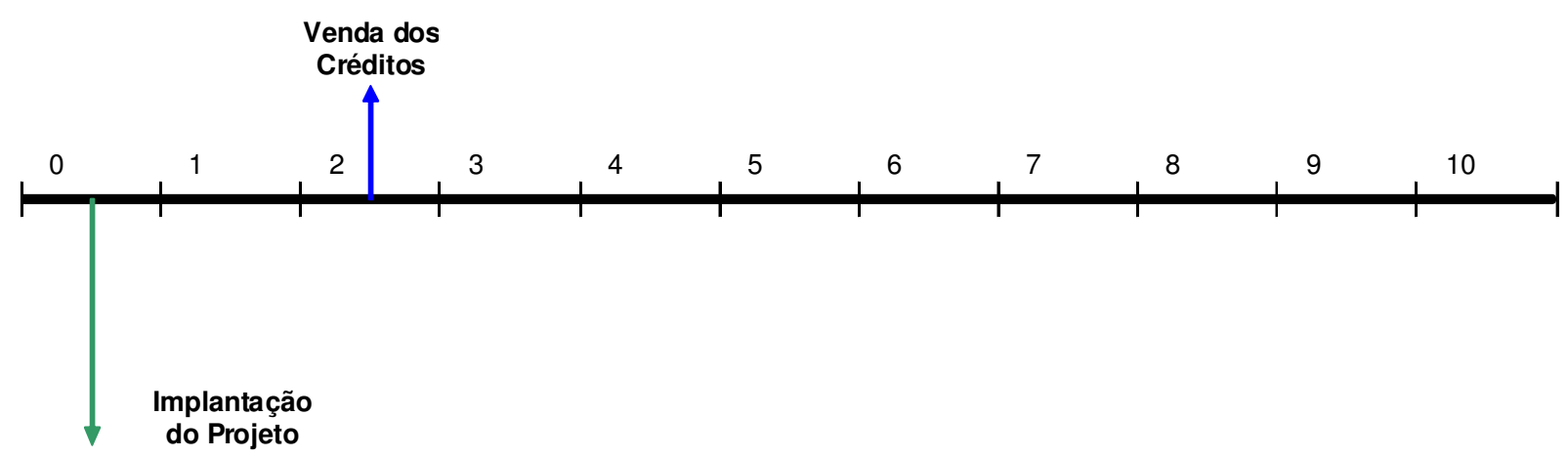

Figura 11 - Venda dos créditos de carbono de uma única vez após recebimento das RCEs Fonte: Elaboração própria

Ainda existe outra possibilidade que seria a venda dos créditos logo no início da implantação do projeto de eficiência energética, de acordo com a figura 12. Neste caso haveria um risco elevado em função da venda ser realizada antes do recebimento das RCEs.

Nesta condição, um eventual problema que ocorra no projeto ou em sua documentação, pode impedi-lo de receber as RCEs que já foram vendidas. Apesar da vantagem financeira da antecipação desta receita dentro do fluxo de caixa do projeto, deve-se analisar cuidadosamente este momento de venda, pois as RCEs sofrem um grande deságio para compensar o elevado risco deste tipo de transação. 


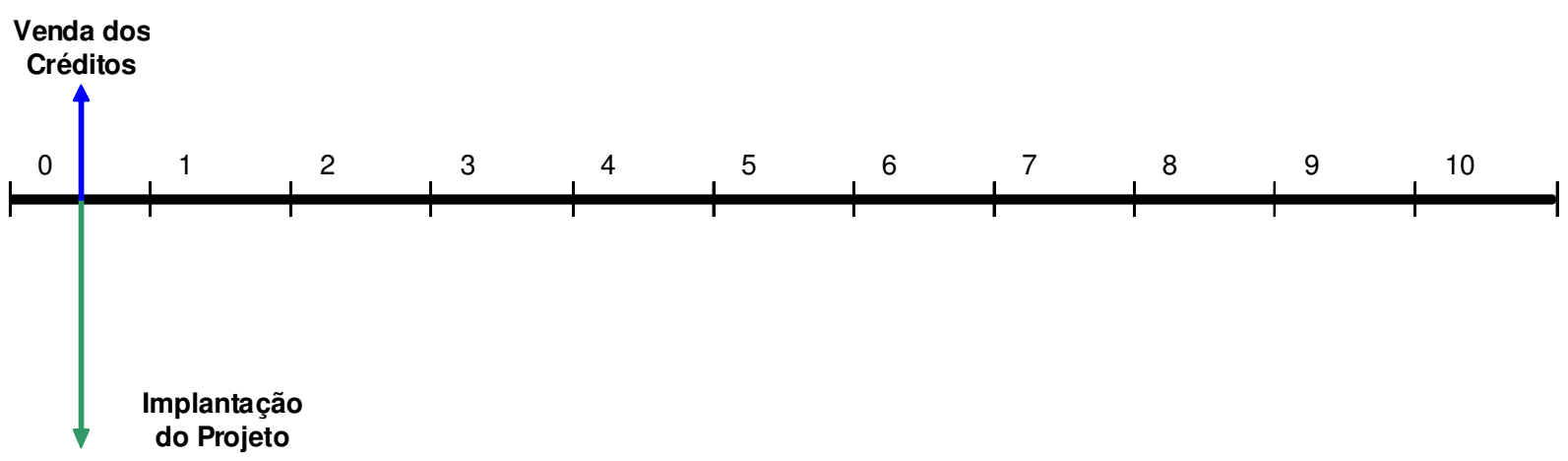

Figura 12 - Venda dos créditos de carbono de uma única vez no início do projeto Fonte: Elaboração própria

\section{2 - Metodologia da linha de base e do monitoramento}

Quando um projeto de MDL é concebido deve-se definir como será calculada a linha de base e como será realizado o monitoramento da redução de emissão de GEE. Existem metodologias diferentes para projetos de pequena escala e para projetos de larga escala. Os projetos de eficiência energética geralmente se enquadram na categoria de pequena escala, que são caracterizados por projetos que tenham uma redução no consumo de energia elétrica inferior a $60 \mathrm{GWh}$ por ano.

Quando o projeto é concebido pode-se utilizar uma metodologia já aprovada pela UNFCCC ou propor uma nova metodologia. Empregar uma metodologia já aprovada impacta na viabilidade do projeto, uma vez que o desenvolvimento de uma nova metodologia requer um custo adicional para sua elaboração.

O site da UNFCCC, acessado em 14/10/08, apresenta 38 metodologias aprovadas para projetos de pequena escala. Dentre estas metodologias cabe destacar sete que podem ser aplicadas em projetos de eficiência energética. Todas as metodologias podem ser obtidas na íntegra em:

http://cdm.unfccc.int/methodologies/SSCmethodologies/approved.html.

AMS-II-C: Demand-side energy efficiency activities for specific technologies AMS-II-D: Energy efficiency and fuel switching measures for industrial facilities AMS-II-E: Energy efficiency and fuel switching measures for buildings AMS-II-F: Energy efficiency and fuel switching measures for agricultural facilities and activities 
AMS-II-H: Energy efficiency measures through centralization of utility provisions of an industrial facility

AMS-II-I: Efficient utilization of waste energy in industrial facilities

AMS-II-J: Demand-side activities for efficient lighting technologies

Em função de já existirem metodologias específicas para projetos de eficiência energética, este trabalho não considera em suas análises 0 custo para 0 desenvolvimento de uma nova metodologia.

5.2.1 - Cálculo do fator de emissão a partir da metodologia ACM0002

A metodologia ACM0002 refere-se à geração de energia elétrica conectada a rede oriunda de fontes renováveis. Apesar de ser uma metodologia de larga escala, o princípio para calcular o fator de emissão nas metodologias de pequena escala, que também tratam do despacho de usinas de energia elétrica gerada a partir de fontes renováveis, é essencialmente o mesmo.

O fator de emissão da linha de base $-E F_{Y}$ é calculado pela média ponderada entre o fator de emissão da margem de operação $-E F_{O M, Y}$ e o fator de emissão da margem de construção $-E F_{B M, Y}$.

$E F_{Y}=W_{O M} \times E F_{O M, Y}+W_{B M} \times E F_{B M, Y}$

Os valores de $W_{O M}$ e $W_{B M}$ ponderam a influencia da margem de operação e da margem de construção sobre o fator de emissão. Por definição é atribuído 0,5 para cada uma das margens, porém pesos alternativos podem ser aplicados, desde que devidamente justificados.

A metodologia ACM0002 apresenta quatro métodos de cálculo da margem de operação, mas de acordo com o Centro de Gestão e Estudos Estratégicos (2008, p. 151) somente o quarto método se aplica ao Brasil em função das informações que estão publicamente disponíveis para a margem de construção. Este fator é chamado de fator de emissão simples ajustado da margem de operação. 


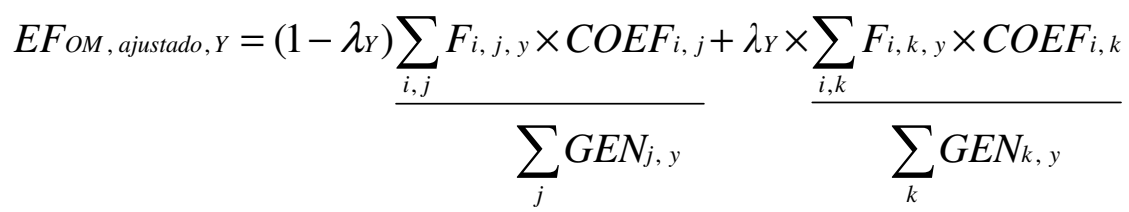

Onde:

$\sum_{i, j} F_{i, j, y} \quad$ é o total de combustível $i$ consumido pelas usinas $j$ no ano $y$;

$C O E F_{i, j}$ é o coeficiente de emissão de dióxido de carbono $\left(\mathrm{CO}_{2}\right)$ do combustível $i$ ( $\mathrm{tCO}_{2}$ /unidade de massa ou volume de combustível), levando-se em conta o potencial de emissão de dióxido de carbono dos combustíveis usados pelas usinas $j$;

$\sum_{j} G E N_{j, y} \quad$ é a eletricidade (em MWh) despachada para o sistema pelas usinas $j$;

$\lambda_{Y} \quad$ é a estimativa da razão do número de horas no ano $y$ (em \%) para o qual plantas de baixo-custo e despacho-inflexível despacham na margem;

$\sum_{i, k} F_{i, k, y} \quad$ é o total de combustível $i$ consumido pelas usinas $k$ no ano $y$;

$C O E F_{i, k}$ é o coeficiente de emissão de dióxido de carbono $\left(\mathrm{CO}_{2}\right)$ do combustível $i$ ( $\mathrm{tCO}_{2} /$ unidade de massa ou volume de combustível), levando-se em conta o potencial de emissão de dióxido de carbono dos combustíveis usados pelas usinas $k$;

$\sum_{k} G E N_{k, y} \quad$ é a eletricidade (em MWh) despachada para o sistema pelas usinas $k$.

Para se determinar a variável $\lambda_{Y}$ é necessário analisar a figura 13 que apresenta no seu eixo $X$ o total de horas de um ano e no eixo $Y$ a potência requerida pelo sistema elétrico. Nos períodos de menor potência somente devem estar em operação as usinas de baixo custo e despacho inflexível, porém quando o sistema necessita de maior potência outras usinas, com custo de operação mais elevado, devem entrar em operação para garantir o equilíbrio entre oferta e demanda do sistema. 


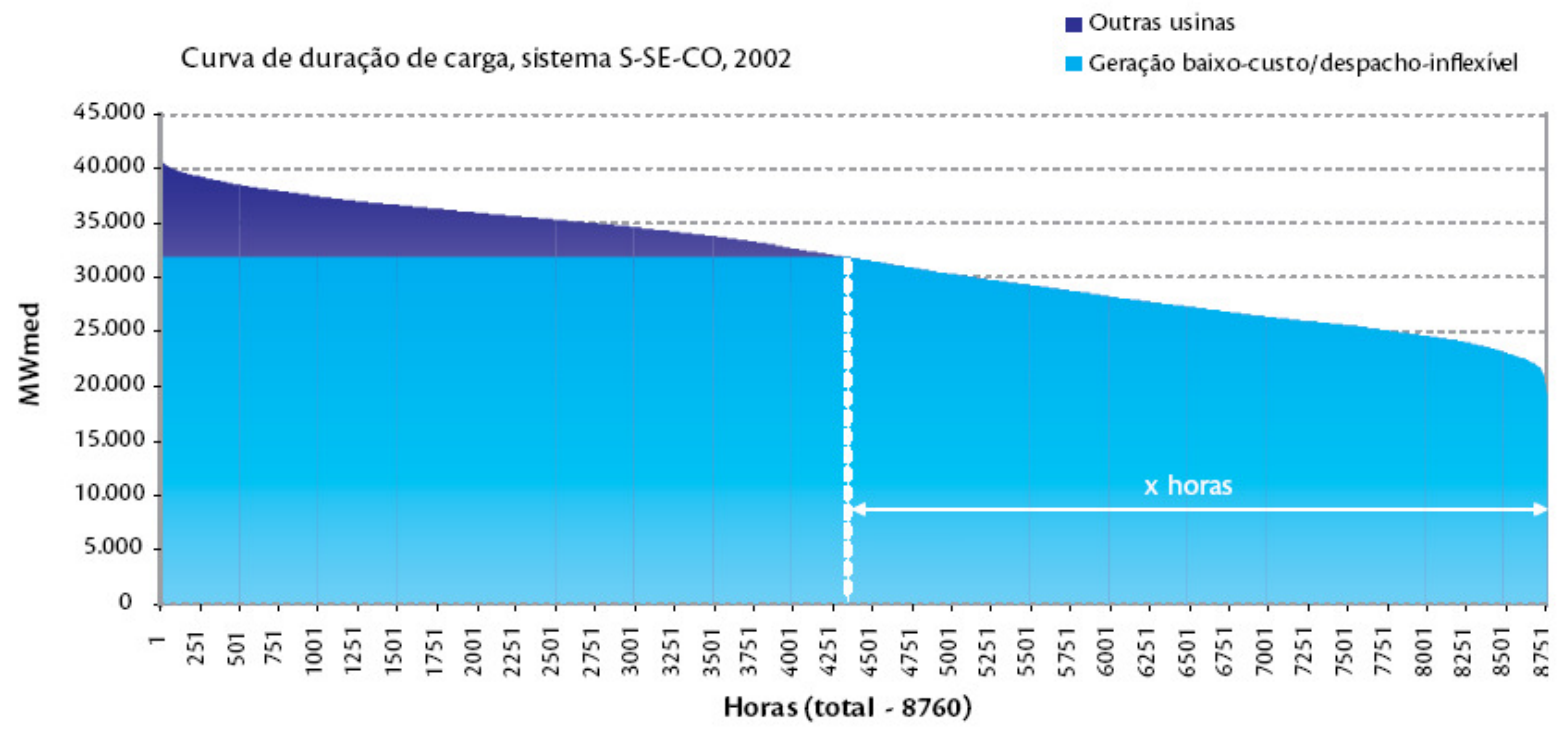

Figura 13 - Exemplo de curva de duração da carga de um Sistema Elétrico Fonte: CENTRO DE GESTÃO E ESTUDOS ESTRATÉGICOS 2008

O fator de emissão da margem de construção é calculado pela média ponderada da geração de emissões de GEE por unidade de eletricidade $\left(\mathrm{tCO}_{2} / \mathrm{MWh}\right)$ de uma amostra de usinas $m$. O grupo de amostra $m$ consiste em uma das alternativas apresentadas a seguir que deve corresponder a maior geração anual de energia elétrica.

- Das cinco usinas que foram construídas mais recentemente;

- Da capacidade adicional das usinas no sistema elétrico que compreende $20 \%$ da geração do sistema (em MWh) e que foi construído mais recentemente.

$$
E F_{B M, Y}=\frac{\sum_{i, m} F_{i, m, y} \times C O E F_{i, m}}{\sum_{m} G E N_{m, y}}
$$

Onde:

$\sum_{i, m} F_{i, m, y} \quad$ é o total de combustível $i$ consumido pelas usinas $m$ no ano $y$;

$C O E F_{i, m}$ é o coeficiente de emissão de dióxido de carbono $\left(\mathrm{CO}_{2}\right)$ do combustível $i$ ( $\mathrm{tCO}_{2}$ /unidade de massa ou volume de combustível), levando-se em 
conta o potencial de emissão de dióxido de carbono dos combustíveis usados pelas usinas $m$;

$\sum_{m} G E N_{m, y} \quad$ é a eletricidade (em MWh) despachada para o sistema pelas usinas $m$.

O Centro de Gestão e Estudos Estratégicos (2008, p. 158) aplicou estas fórmulas no sistema elétrico brasileiro, considerando o ano base 2005, resultando em um fator de emissão de 0,279 $\mathrm{tCO}_{2} / \mathrm{MWh}$ para o sub-sistema Sul, Sudeste e Centro-Oeste e um fator de 0,153 $\mathrm{tCO}_{2} / \mathrm{MWh}$ para o sub-sistema Norte Nordeste, conforme tabelas 2 e 3 respectivamente.

Tabela 2 - Fator de emissão para o subsistema Sul, Sudeste e Centro Oeste do Sistema Interligado Nacional - Ano base 2005

\begin{tabular}{lcr}
\hline \multicolumn{2}{c}{ Fator de emissão para o subsistema Sul, Sudeste e Centro Oeste } \\
\hline EF OM ,Ajustado,Y & $\left(\mathrm{tCO}_{2} / \mathrm{MWh}\right)$ & 0,4701 \\
$\mathrm{EF} \mathrm{BM}, \mathrm{Y}$ & $(\mathrm{tCO} / \mathrm{MWh})$ & 0,0872 \\
$\lambda 2005$ & $\%$ & 51,3 \\
Wom Alternativo & $\%$ & 75 \\
WBM Alternativo & $\%$ & 25 \\
EFY Padrão & $(\mathrm{tCO} / \mathrm{MWh})$ & 0,279 \\
EFY Alternativo & $(\mathrm{tCO} / \mathrm{MWh})$ & 0,374 \\
\hline
\end{tabular}

Fonte: Elaboração própria adaptado de Centro de Gestão e Estudos Estratégicos (2008, p. 158)

Tabela 3 - Fator de emissão para o subsistema Norte e Nordeste do Sistema Interligado Nacional Ano base 2005

\begin{tabular}{lcr}
\hline \multicolumn{3}{c}{ Fator de emissão para o subsistema Norte e Nordeste } \\
\hline EF OM,Ajustado,Y & (tCO $2 / \mathrm{MWh})$ & 0,1874 \\
EF BM, $\mathrm{Y}$ & $(\mathrm{tCO} / \mathrm{MWh})$ & 0,0491 \\
$\lambda_{2005}$ & $\%$ & 55,72 \\
WOM Alternativo & $\%$ & 75 \\
WBM Alternativo & $\%$ & 25 \\
EFY Padrão & $(\mathrm{tCO} / \mathrm{MWh})$ & 0,118 \\
EFY Alternativo & $(\mathrm{tCO} / \mathrm{MWh})$ & 0,153 \\
\hline
\end{tabular}

Fonte: Elaboração própria adaptado de Centro de Gestão e Estudos Estratégicos (2008, p. 158)

\section{3 - Modelagem da análise de viabilidade}

Um estudo de viabilidade requer análises quantitativas e qualitativas. Quantitativamente são calculados indicadores financeiros, que em um projeto de 
eficiência energética são obtidos levando em consideração a receita advinda da economia de energia em comparação com a despesa do investimento requerido.

No aspecto qualitativo um estudo de viabilidade deve ser realizado ponderando os riscos internos e externos de execução do projeto.

Um estudo de viabilidade requer inicialmente que sejam coletadas todas as informações relativas ao projeto. A experiência adquirida em projetos anteriores contribui para reduzir eventuais erros de levantamento de dados.

Depois de reunida uma massa de dados é necessário tratá-la e analisá-la, a fim de desenvolver as soluções passíveis de serem aplicadas no local, com o intuito de aumentar a eficiência no consumo de energia.

A tomada de decisão sobre a execução de um projeto em geral é realizada com base em fatos e dados, por este motivo o estudo de viabilidade é fundamental para subsidiar de informações as pessoas que decidem sobre a realização do projeto. Para que seja possível analisar a viabilidade de um projeto, é necessário selecionar os indicadores de análise. O próximo item apresenta os indicadores utilizados para realizar uma análise financeira.

\subsection{1 - Indicadores financeiros de análise}

O Pay Back simples é uma das técnicas de análise de investimento mais comuns. Este método visa calcular quanto tempo o investidor irá precisar para recuperar o capital investido a partir das receitas advindas da realização do projeto.

Entretanto, o Pay Back simples apresenta uma falha ao não considerar a taxa de juros. Para suprir essa deficiência é possível aplicar o Pay Back descontado, que além de levar em consideração a taxa de juros, permite a variação de valores de economia ao longo do período analisado.

Ambos os indicadores não se atém aos possíveis fluxos de caixa após o tempo de recuperação do investimento, e para que o Pay Back seja o desejado, pode incorrer em taxas de juros que não são praticadas no mercado.

O Valor Presente Líquido - VPL é calculado para se determinar o valor presente de pagamentos futuros descontados a uma taxa de juros definida, menos o custo do investimento inicial. Basicamente, é o cálculo de quanto as receitas e/ou 
pagamentos futuros, somados a um custo inicial, estariam valendo atualmente. É preciso considerar o conceito de valor do dinheiro no tempo em função do custo de oportunidade de se colocar o dinheiro, por exemplo, em uma aplicação financeira em relação a aplicar este mesmo dinheiro na realização do projeto.

$V P L=-C i v+\sum_{t=1}^{T} F C t /(1+i)^{t}$

Onde:

Civ é o custo de investimento;

FC é o fluxo de caixa do período $t$;

$t \quad$ é o número do períodos em que foi determinado o fluxo de caixa;

$i \quad$ é a taxa de juros (custo de oportunidade);

$T \quad$ é o período total do fluxo de caixa, sendo este um múltiplo inteiro de $t$;

A Taxa Interna de Retorno - TIR é a taxa necessária para igualar o valor de um investimento (valor presente) com os seus respectivos retornos futuros ou saldos de caixa. Aplicada em análise de investimentos, significa a taxa de retorno de um projeto, isto quer dizer que a TIR é a taxa que anula o VPL.

$0=-C i v+\sum_{t=1}^{T} F C t /(1+T I R)^{t}$

Onde:

Civ $\quad$ é o custo de investimento;

FC é o fluxo de caixa do período $t$;

$t \quad$ é o número do períodos em que foi determinado o fluxo de caixa.

$T \quad$ é o período total do fluxo de caixa, sendo este um múltiplo inteiro de $t$; 
Sua utilização permite a avaliação de viabilidade de um projeto, sem depender da taxa de juros vigente no mercado. A TIR é um número intrínseco ao projeto e não depende de nenhum outro parâmetro que não seja o fluxo de caixa esperado.

Para a realização da análise proposta neste trabalho serão utilizados os indicadores VPL e TIR, pois os dois valores apresentam as informações necessárias para analisar o desempenho financeiro de um projeto.

\subsection{2 - Elaboração do fluxo de caixa}

Para calcular os indicadores TIR e VPL é necessário construir o fluxo de caixa do projeto, apontando as receitas e despesas relacionadas a sua execução, dentro do período horizonte analisado.

Inicialmente deve-se determinar o período base para realização dos cálculos. Em função do tempo de maturação de um projeto desta natureza e do período de validação definido pelas regras do Protocolo de Quioto, esta análise considera o período base de um ano.

Também se faz necessária a definição do período horizonte do projeto. Todo projeto de MDL pode dispor de um período de dez anos ou de três períodos de sete anos (neste caso deve ser realizada uma renovação da aprovação a cada período). Este trabalho considera o período horizonte de dez anos para realização do projeto de MDL por ser o período usualmente escolhido nos projetos existentes.

$\mathrm{Na}$ análise modelada neste trabalho a implantação do projeto de eficiência energética ocorre no período de um ano, denominado como ano zero. Concomitantemente ocorre todo o processo de implantação do projeto de MDL, bem como a auditoria de implantação, fazendo com que o ano zero da modelagem tenha duas despesas e nenhuma receita.

O fluxo de caixa considera a venda das RCEs anualmente, por se tratar da forma mais conservadora de venda, conforme estudado no item 5.1 deste trabalho.

Durante os dez anos em que são vendidas as RCEs, deve ser realizada periodicamente uma auditoria de verificação, a fim de se confirmar se a redução de emissão de GEE realmente ocorreu na quantidade prevista e eventualmente, realizar ajustes. 
A economia de energia é considerada na modelagem como uma receita durante o horizonte de dez anos definido no projeto. A venda das RCEs é considerada a segunda fonte de receita do projeto, que também ocorre anualmente durante 0 período de dez anos. A figura 14 apresenta o fluxo de caixa de um projeto.

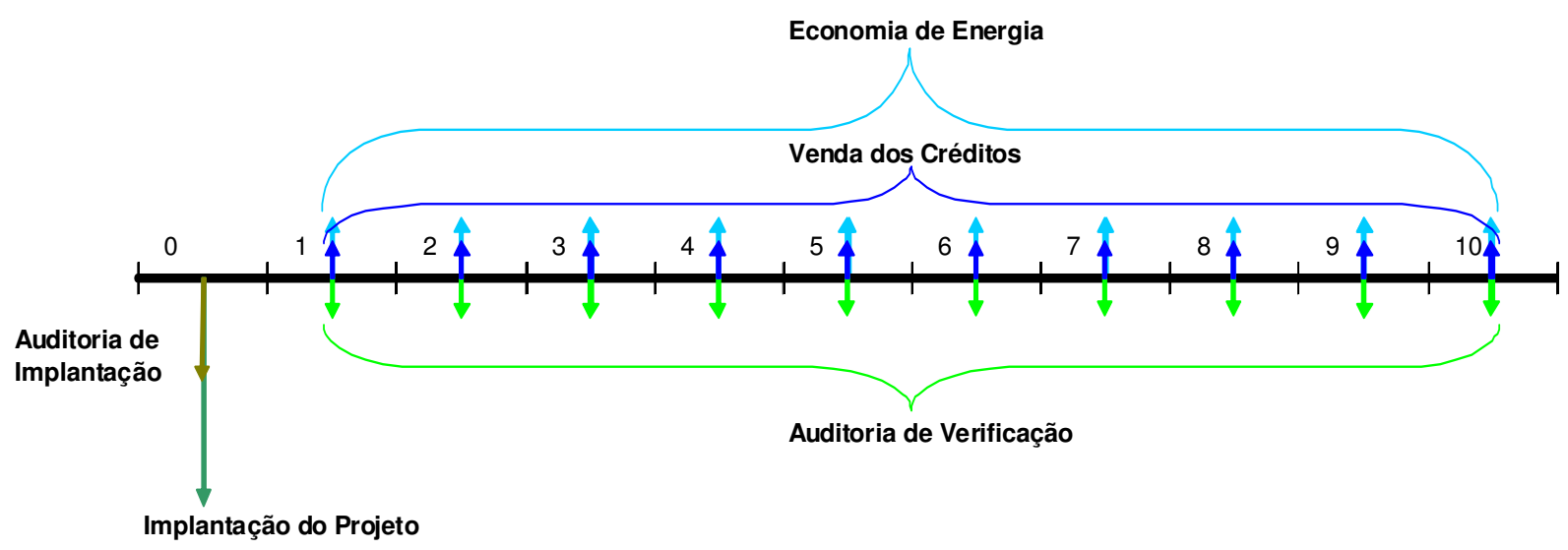

Figura 14 - Fluxo de caixa de um projeto de eficiência energética com MDL

Fonte: Elaboração própria

\subsection{3 - Redução da despesa com energia elétrica}

De acordo com o fluxo de caixa elaborado no item anterior, a modelagem apresenta duas fontes de receita, uma advinda da redução da despesa com energia elétrica, em função da maior eficiência em seu consumo, e outra obtida com a venda das RCEs.

Para calcular a redução da despesa com a energia elétrica, deve-se utilizar a mesma metodologia que as distribuidoras empregam, a fim de espelhar o resultado real na conta de energia.

A tarifa é o fator que faz a conversão de energia elétrica em dinheiro e esta tarifa é variável dependendo da distribuidora de energia. Dentro de uma mesma distribuidora a tarifa ainda pode variar dependendo da tensão ao qual o consumidor se conecta à rede elétrica e também dependendo da opção tarifária adotada por ele. A modelagem deste trabalho considera a tarifa da AES-Eletropaulo no segundo semestre de 2008.

Primeiramente deve ser analisado se o consumidor está conectado em baixa ou alta tensão. Em geral os projetos de eficiência energética são realizados em 
consumidores de energia de grande porte, portanto este trabalho considera que o consumidor está conectado em uma rede de alta tensão.

Por se tratar de uma ligação em alta tensão, automaticamente este consumidor é faturado pela energia consumida e pela demanda requerida da rede de distribuição. Adicionalmente deve ser identificada também a tensão na qual este consumidor está conectado, para avaliar o seu enquadramento em um dos subgrupos tarifários abaixo:

A1 - $230 \mathrm{kV}$ ou mais

A2 - $88 \mathrm{kV}$ a $138 \mathrm{kV}$

A3 - $69 \mathrm{kV}$

$\mathrm{A} 3 \mathrm{a}-30 \mathrm{kV}$ a $44 \mathrm{kV}$

A4 - 2,3 kV a $25 \mathrm{kV}$

Como a grande maioria dos consumidores de alta tensão está conectada na faixa de tensão compreendida do subgrupo A4, a modelagem utiliza esta tarifa para análise. Dentro do subgrupo ainda se faz necessária a definição da modalidade tarifária, que pode ser "Azul", "Verde" ou "Convencional".

A modalidade "Convencional" somente se aplica para instalações com demanda inferior a $300 \mathrm{~kW}$, que é considerada uma potência pequena para o perfil dos projetos de eficiência energética estudados. Dentre as outras duas modalidades tarifárias a "Azul" é a mais usual, sendo assim, esta é a modalidade escolhida para calcular a economia de energia.

Portanto, a modelagem deste trabalho considera a tarifa de energia do segundo semestre de 2008 da AES-Eletropaulo de um consumidor conectado no sub-grupo A4 na modalidade tarifária "Azul".

A totalização da redução da despesa com energia elétrica é obtida com a soma dos itens a seguir acrescida dos devidos impostos:

- Economia de energia na ponta;

- Economia de energia fora de ponta;

- Redução de demanda na ponta;

- Redução de demanda fora de ponta; 
Como a modelagem utiliza um período base anual é necessário avaliar o impacto da variação da tarifa nos períodos úmido e seco ${ }^{7}$. Como as tarifas são diferentes nestes períodos, a modelagem utiliza uma média ponderada, considerando que em sete meses do ano utiliza-se a tarifa do período seco e nos cinco meses complementares utiliza-se a tarifa do período úmido.

Não está sendo considerada tarifação da ultrapassagem de demanda, afinal uma boa gestão do consumo de energia de uma instalação deve eliminar o pagamento desta tarifa adicional. Mesmo que a instalação esteja pagando esta multa, o projeto de eficiência energética deve contribuir para a redução da demanda da instalação, reduzindo assim a possibilidade de ultrapassagem da demanda contratada.

Também não está sendo considerada tarifação de multa por baixo fator de potência, porque a maior parte dos equipamentos utilizados em projetos de eficiência energética possui um elevado fator de potência, contribuindo assim, para a melhora do fator de potência global da instalação.

\subsection{4 - Contabilização da venda de RCEs}

Além da redução da despesa com energia elétrica a modelagem deste trabalho considera uma segunda fonte de receita a partir da venda das RCEs. Primeiramente é necessário definir qual é a quantidade de RCEs gerada pelo projeto. Para se obter esta informação deve-se multiplicar a economia anual de energia, dada em MWh, pelo fator de emissão, dado em $\mathrm{tCO}_{2} / \mathrm{MWh}$. O resultado obtido é a quantidade de $\mathrm{CO}_{2}$ evitada de ser emitida, dada em toneladas, que corresponde à quantidade de RCEs gerada pelo projeto.

Sobre a quantidade de RCEs calculada devem ser debitados $2 \%$, que é contingenciado pela UNFCCC, sendo o resultado correspondente à quantidade de RCEs disponíveis para venda oriunda do projeto.

Uma vez multiplicado o valor da tonelada de carbono sobre a quantidade de RCEs

\footnotetext{
${ }^{7}$ Período úmido: meses compreendidos entre dezembro e abril. Período seco: meses compreendidos entre maio e novembro.
} 
disponíveis para venda, obtém-se a receita financeira desta transação. Este trabalho utiliza o preço da tonelada de carbono em Euro por ser a moeda utilizada internacionalmente neste mercado.

Por se tratar de uma operação de venda deve haver uma tributação sobre esta transação, porém não há legislação específica para este tipo de operação, portanto a apuração dos tributos aplicáveis deve ser obtida a partir de uma análise na Constituição Federal de 1988. Souza (2007. p. 264) faz a seguinte análise.

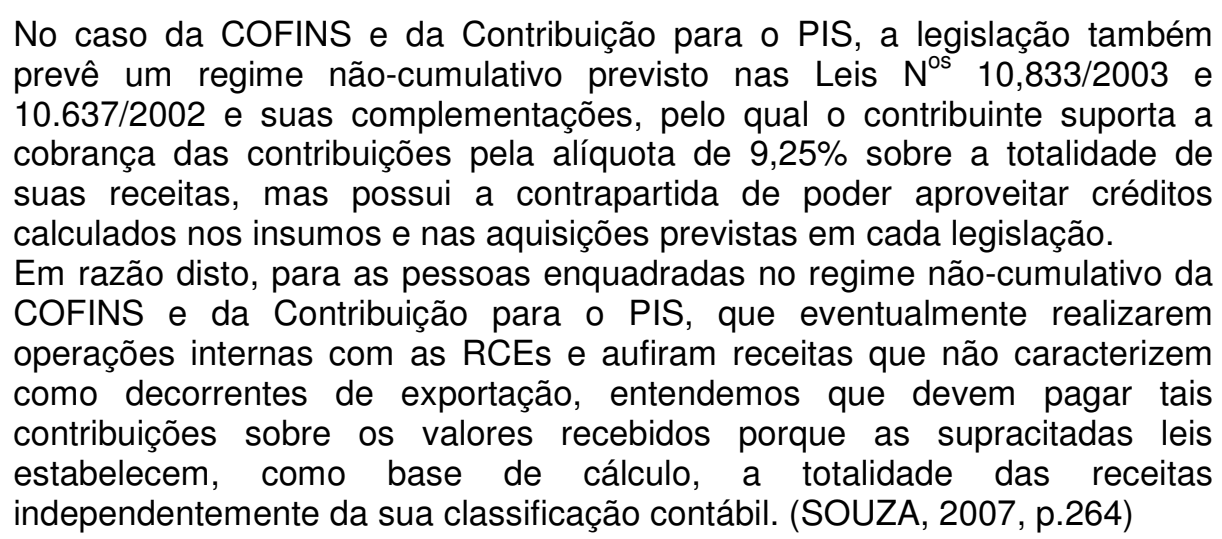

Sendo assim, esta modelagem considera a incidência dos impostos PIS e Cofins, aplicando a alíquota de $9,25 \%$ sobre o valor da venda das RCEs. O resultado entre o valor de venda menos os impostos é a receita líquida, oriunda dos créditos de carbono, considerada no fluxo de caixa do projeto.

\section{4 - Aplicação da metodologia em casos reais}

Sobre a modelagem desenvolvida neste trabalho foram aplicados os dados de quatro projetos de eficiência energética realizados por empresas do setor de energia, a fim de verificar o desempenho financeiro do projeto original e comparar com o seu desempenho quando inserido o projeto de MDL. Para realizar as simulações três informações básicas são necessárias para realização dos cálculos:

- Investimento total;

- Redução de demanda;

- Economia de energia; 
Com a inserção destas três informações principais no quadro "DADOS DO PROJETO", a planilha de modelagem, apresentada em detalhes no Anexo A, realiza todos os cálculos necessários, apresentando um resultado de VPL e TIR para o projeto original de eficiência energética da forma como ele foi realizado, e outro valor de VPL e TIR para o mesmo projeto após a inserção das despesas e receitas referentes ao projeto de MDL.

Os quatro projetos que serão apresentados nos próximos itens possuem portes distintos, a fim de se avaliar o impacto no desempenho financeiro em projetos de diferentes tamanhos. Os projetos variam em valores de investimento de $R \$ 0,5$ milhão até um agrupamento de projetos que totaliza $\mathrm{R} \$ 13$ milhões.

Para realizar as simulações é necessária a inserção das variáveis do quadro "PREMISSAS". Os primeiros campos se referem à tarifa de energia, que neste caso foi considerada a tarifa da AES-Eletropaulo no segundo semestre de 2008, para um cliente do subgrupo A4 na tarifa "Azul". O fator de conversão de $€$ para R $\$$ utilizado é de 2,5 e o fator de emissão adotado é $0,279 \mathrm{tCO}_{2} / \mathrm{MWh}$, este valor foi extraído do Centro de Gestão e Estudos Estratégicos (2008, p. 158) para o submercado sul/sudeste/centro-este, utilizando a metodologia ACM002 com o ano base 2005.

A alíquota de PIS+Cofins utilizada é de 9,25\%, o preço do crédito de €19,2 é o valor negociado no leilão ocorrido no ano de 2008 em São Paulo. O preço para realização das auditorias de implantação e de verificação também foram retirados do Centro de Gestão e Estudos Estratégicos (2008, p. 118), que apresenta uma faixa de variação destes preços de US $\$ 60.000,00$ à US $\$ 175.000,00$. Como os projetos de eficiência energética em geral se enquadram na categoria de pequena escala e considerando a utilização de uma metodologia já existente, este trabalho utiliza o menor valor de US $\$ 60.000,00$ com uma taxa de conversão para Reais de 2:1, ou seja $R \$ 120.000,00$ divididos em $R \$ 90.000,00$ para a auditoria de implantação, $R \$ 20.000,00$ para os ativos de verificação e $R \$ 10.000,00$ para a auditoria de verificação.

A taxa de desconto utilizada para o cálculo do VPL é de 13,75\%, que representa a taxa Selic do mês de outubro de 2008. A taxa Selic foi escolhida por representar o custo de oportunidade que o montante de recurso necessário para realização de um projeto de eficiência energética renderia em uma aplicação bancária. Sobre o lucro do projeto é aplicado o imposto de renda, a uma taxa de $34 \%$. 
A taxa anual de crescimento constante no quadro "PREMISSAS" é aplicada sobre a tarifa de energia, preço da auditoria de verificação anual, preço do crédito de carbono e preço dos ativos de verificação para fins cálculo da depreciação.

Cada um destes parâmetros pode aumentar de preço periodicamente devido a fatores alheios às pessoas que estão trabalhando no desenvolvimento do projeto, como por exemplo, a tarifa de energia que além do aumento dos custos operacionais, que são relativamente previsíveis, também é impactada pelos custos de geração de energia no país, pela melhora da eficiência operacional das distribuidoras, pelo dólar aplicado sobre a energia oriunda da Usina Binacional de Itaipu, dentre outras variáveis que tornam a estimativa de um índice de crescimento muito complexo e de difícil assertividade.

Prever o preço da tonelada de carbono para os próximos anos também é complexo porque este preço é negociado no livre mercado, em leilões que podem inflacionar ou depreciar este preço dependendo dos atores envolvidos. A definição que ocorrerá na reunião da Conferência das Partes no final de 2009 sobre as metas obrigatórias de redução de emissões de GEE após 2012, também pode influenciar enormemente o preço da tonelada de carbono no mercado internacional.

Sendo assim as análises realizadas neste trabalho considera um valor médio de $8 \%$ para a taxa anual de crescimento.

\subsection{1 - Sistema de bombeamento da SAMAE de Caxias do Sul}

A Esco APS Engenharia de Energia, localizada em Porto Alegre - RS, realizou um projeto de eficiência energética na Samae - Serviço Autônomo Municipal de Água e Esgoto do município de Caxias do Sul - RS, autarquia vinculada à Prefeitura de Caxias do Sul. A Samae é responsável pela captação, tratamento, armazenamento e distribuição de água da região. Este projeto foi apresentado no $5^{\circ}$ Congresso Brasileiro de Eficiência Energética e Cogeração de Energia em 2008.

O projeto consiste da atuação no sistema de supervisão e controle de estações elevatórias de água tratada. Com um investimento de $\mathrm{R} \$ 558.160,11$ o projeto gerou uma economia anual de energia de 501,53 MWh e uma redução de demanda no horário de ponta de $214,8 \mathrm{~kW}$. 
A inserção destas despesas e receitas na planilha de modelagem, indica que o VPL do projeto original é de $\mathrm{R} \$ 538.496,00$ e a inserção do projeto de MDL reduz este valor para $\mathrm{R} \$ 414.577,00$.

A TIR original do projeto é de $32,2 \%$, sendo que a inserção do projeto de MDL alterou este valor para $26,2 \%$, neste caso, o projeto tem o seu desempenho financeiro reduzido com a inserção do projeto de MDL. 
Tabela 4 - Fluxo de caixa e cálculo do VPL e da TIR do projeto de eficiência energética da Samae com e sem MDL

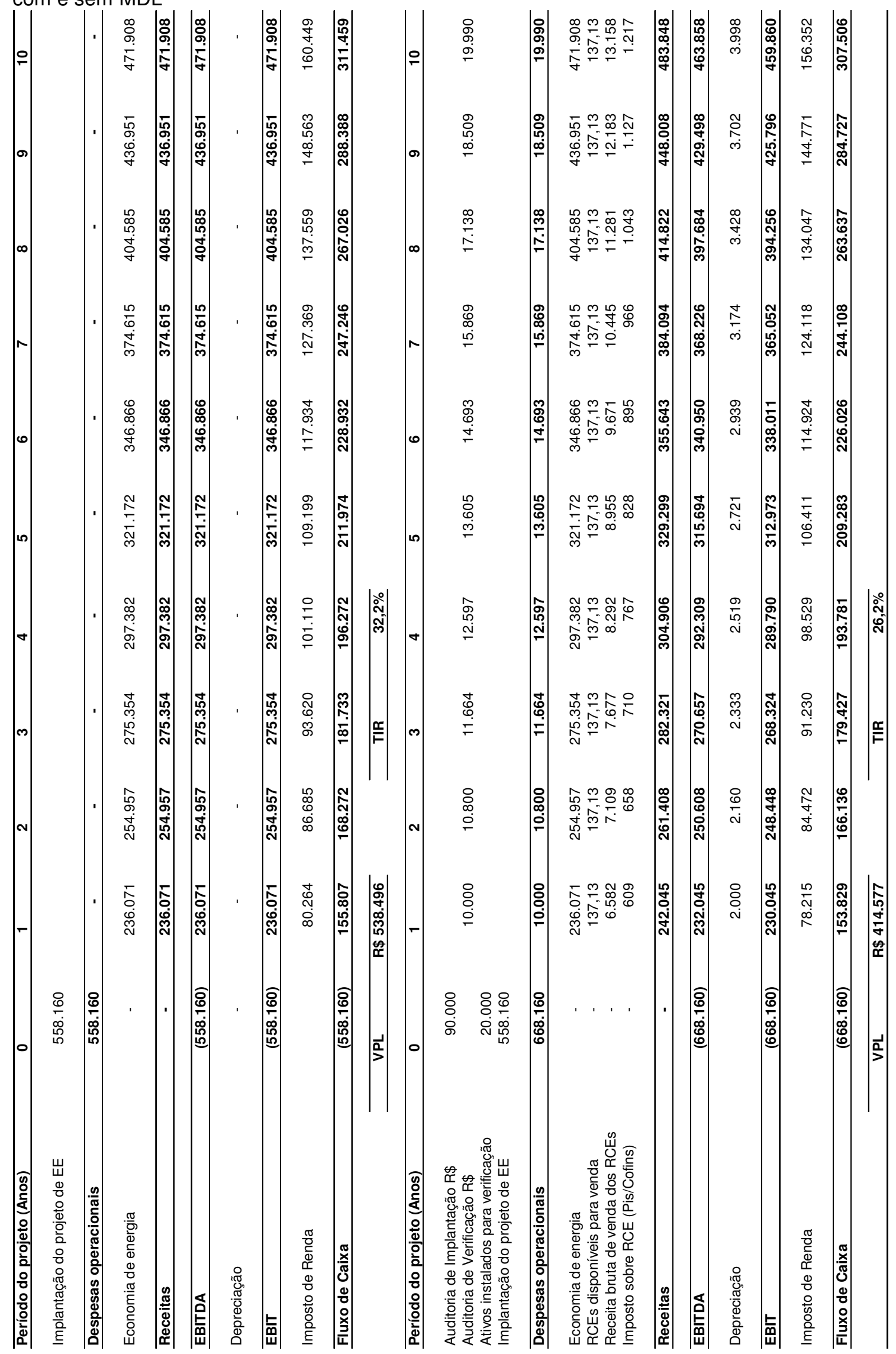

Fonte: Elaboração própria 


\subsection{2 - Sistema de ar condicionado da Prefeitura de Recife}

A Celpe - Companhia Energética de Pernambuco, apresentou no Seminário Nacional de Distribuição de Energia Elétrica - Sendi em 2008, um projeto de eficiência energética realizado no sistema de ar condicionado da Prefeitura Municipal de Recife.

O projeto contemplou a substituição de dois chillers de 500 TR cada, mais a troca das bombas de condensação, bombas de água gelada e das torres de resfriamento, por equipamentos de capacidade similar, porém mais eficientes.

Como resultado este projeto apresentou uma economia anual de energia de 757,12 MWh e uma redução de demanda no horário de ponta de 566,4 kW. Para que fosse possível a realização do projeto a Celpe aplicou $R \$ 1.629 .123,25$ entre equipamentos e mão de obra.

Aplicando estes valores na modelagem desenvolvida neste trabalho, é possível obter o valor do VLP original do projeto de $R \$ 751.032,00$ contra um valor de $\mathrm{R} \$ 641.253,00$ após a inserção do projeto de MDL. A TIR do projeto original é de $23,2 \%$, contra um valor de $21,4 \%$ após a inserção do projeto de MDL. Desta forma, tanto o VPL quanto a TIR foram reduzidos com a inserção das receitas e despesas advindas do projeto de MDL. 
Tabela 5 - Fluxo de caixa e cálculo do VPL e da TIR do projeto de eficiência energética da Prefeitura de Recife com e sem MDL

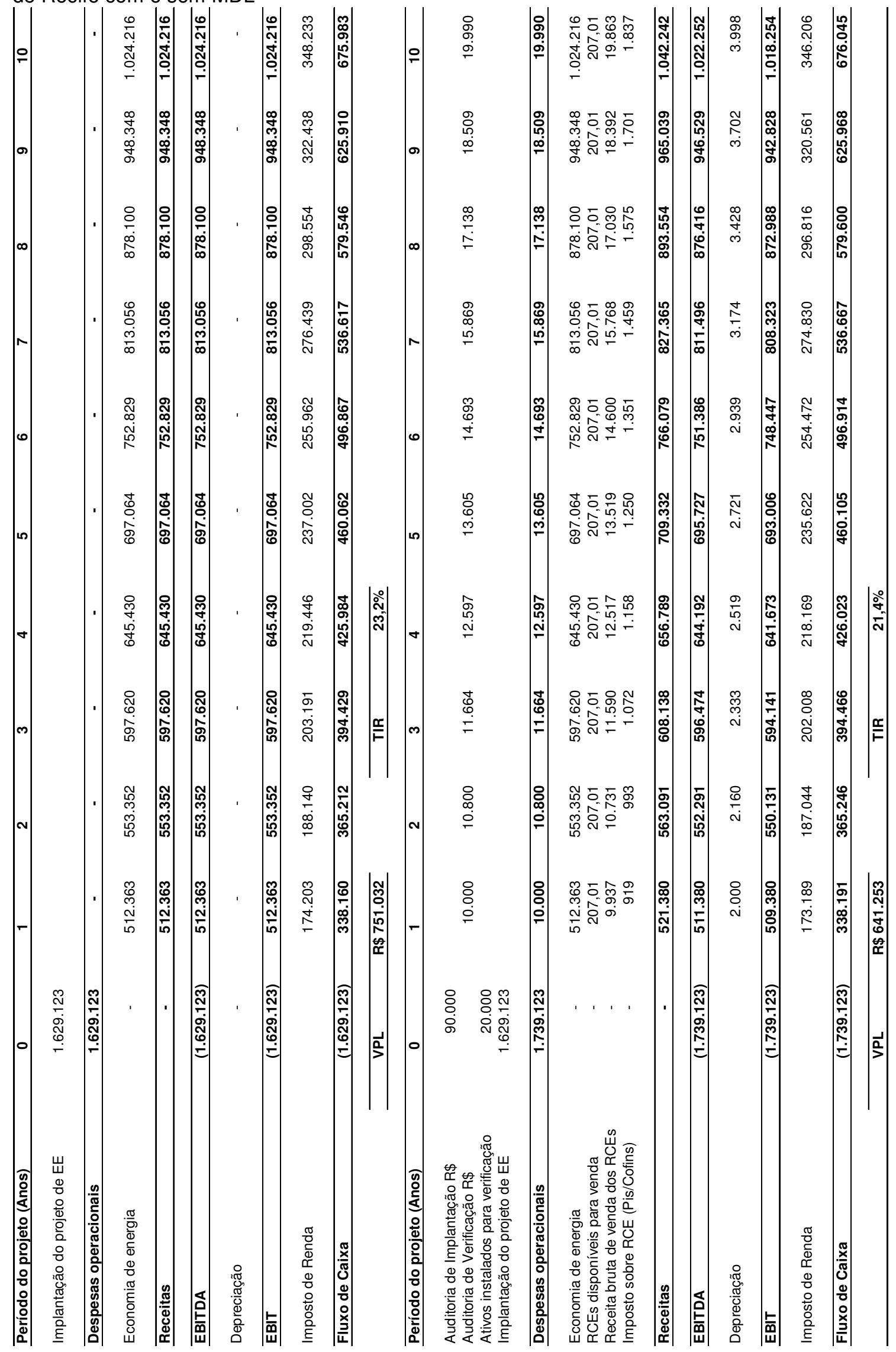

Fonte: Elaboração própria 


\subsection{3 - Sistema de bombeamento}

A CPFL - Companhia Paulista de Força e Luz apresentou um resumo dos resultados do seu PEE no 4ํ Congresso Brasileiro de Eficiência Energética e Cogeração de Energia em 2007, com destaque para o setor de saneamento.

De acordo com as projeções a CPFL realizou projetos de eficiência energética em instalações de serviços de água e esgoto em oito clientes no ano de 2007, totalizando um investimento da ordem de $R \$ 4.661 .000,00$, resultando em uma economia de energia de $6.951 \mathrm{MWh} /$ ano e uma redução de demanda no horário de ponta de $840 \mathrm{~kW}$.

Para obter estes resultados os projetos atuaram na substituição de motores antigos por motores novos de elevada eficiência, instalação de inversores de freqüência e investimento em sistemas de automação.

Aplicando as informações principais deste conjunto de projetos na planilha de modelagem deste trabalho, o desempenho financeiro é aumentado quando inserida as receitas e despesas do projeto de MDL.

O projeto original de eficiência energética possui um VPL de $R \$ 4.142 .805,00$, contra um valor de $\mathrm{R} \$ 4.375 .722,00$ a partir da inserção do projeto de MDL. A TIR do projeto original de eficiência energética apresenta um valor de 30,9\%, enquanto o mesmo projeto, com a inserção das despesas e receitas referentes ao projeto de MDL, aumenta para $31,4 \%$. 
Tabela 6 - Fluxo de caixa e cálculo do VPL e da TIR do projeto de eficiência energética em sistemas de bombeamento da CPFL com e sem MDL

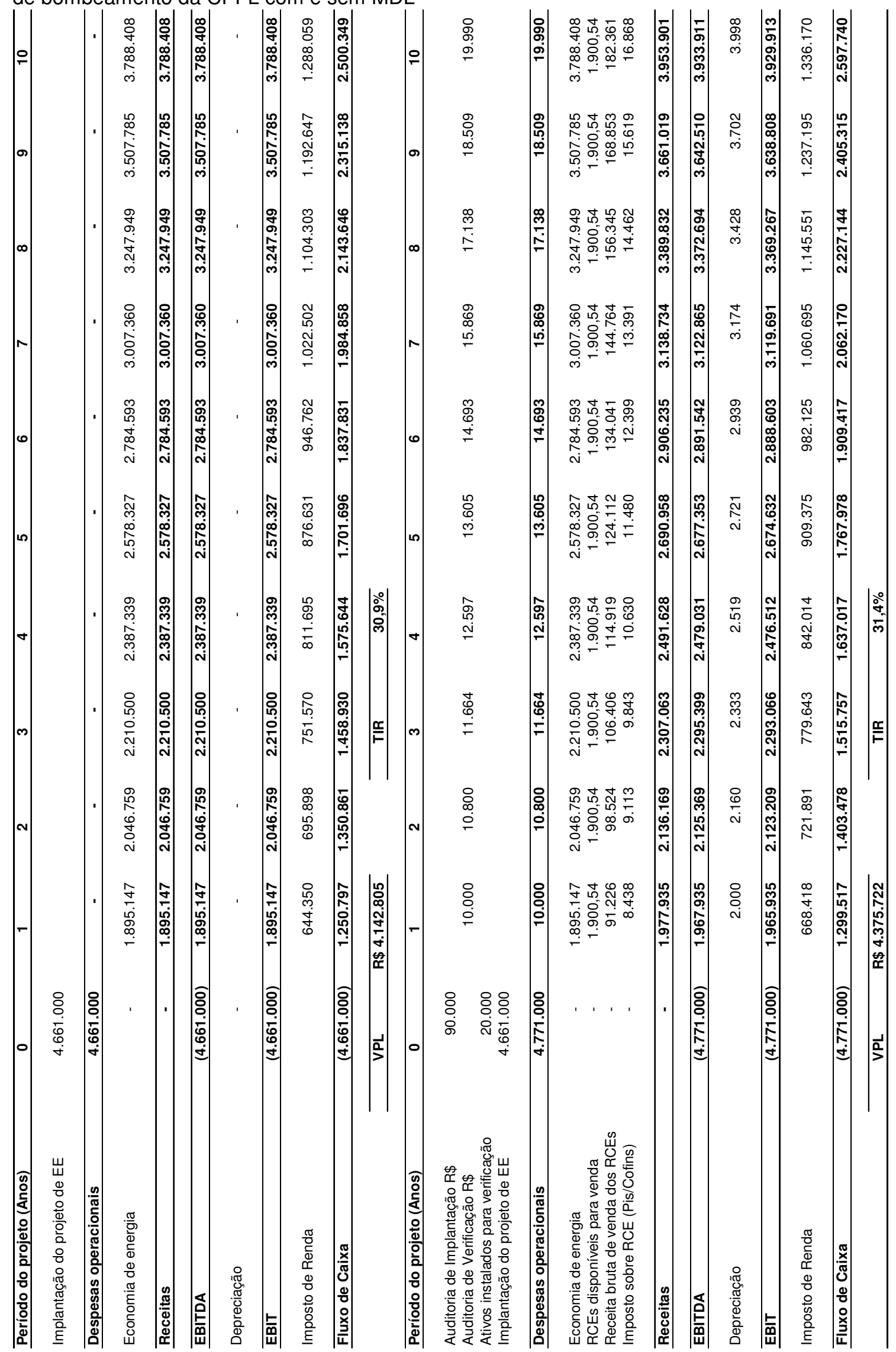

Fonte: Elaboração própria 


\subsection{4 - Projeto educacional}

A AES-Eletropaulo apresentou no $5^{\circ}$ Congresso Brasileiro de Eficiência Energética e Cogeração de Energia de 2008, um agrupamento de projetos realizados na área educacional.

Este grupo de projetos atingiu 207 escolas municipais, 118 escolas estaduais, reitoria e faculdade de direito da USP-SP, universidades e escolas técnicas. Predominantemente os projetos foram dirigidos para melhorar a eficiência no sistema de iluminação com a substituição de lâmpadas, reatores e luminárias ineficientes por equipamentos novos e de maior eficiência. Em poucos casos o projeto também contemplou o sistema de climatização ambiental.

Em resumo, este agrupamento de projetos demandou um investimento da ordem de $\mathrm{R} \$ 13.200 .000,00$ resultando em uma economia de energia de 15.496 MWh anuais e uma redução de demanda no horário de ponta de 4.164 kW.

Aplicando estes dados na modelagem deste trabalho, obtém-se o VPL do projeto original de eficiência energética de $R \$ 13.283 .758,00$ e a inserção das despesas e receitas do projeto de MDL aumentou este valor para $R \$ 13.989 .454,00$. A TIR calculada do projeto original é de $32,9 \%$ e a TIR com a inserção do projeto de MDL aumenta para $33,7 \%$. 
Tabela 7 - Fluxo de caixa e cálculo do VPL e da TIR do projeto de eficiência energética em entidades educacionais da AES-Eletropaulo com e sem MDL

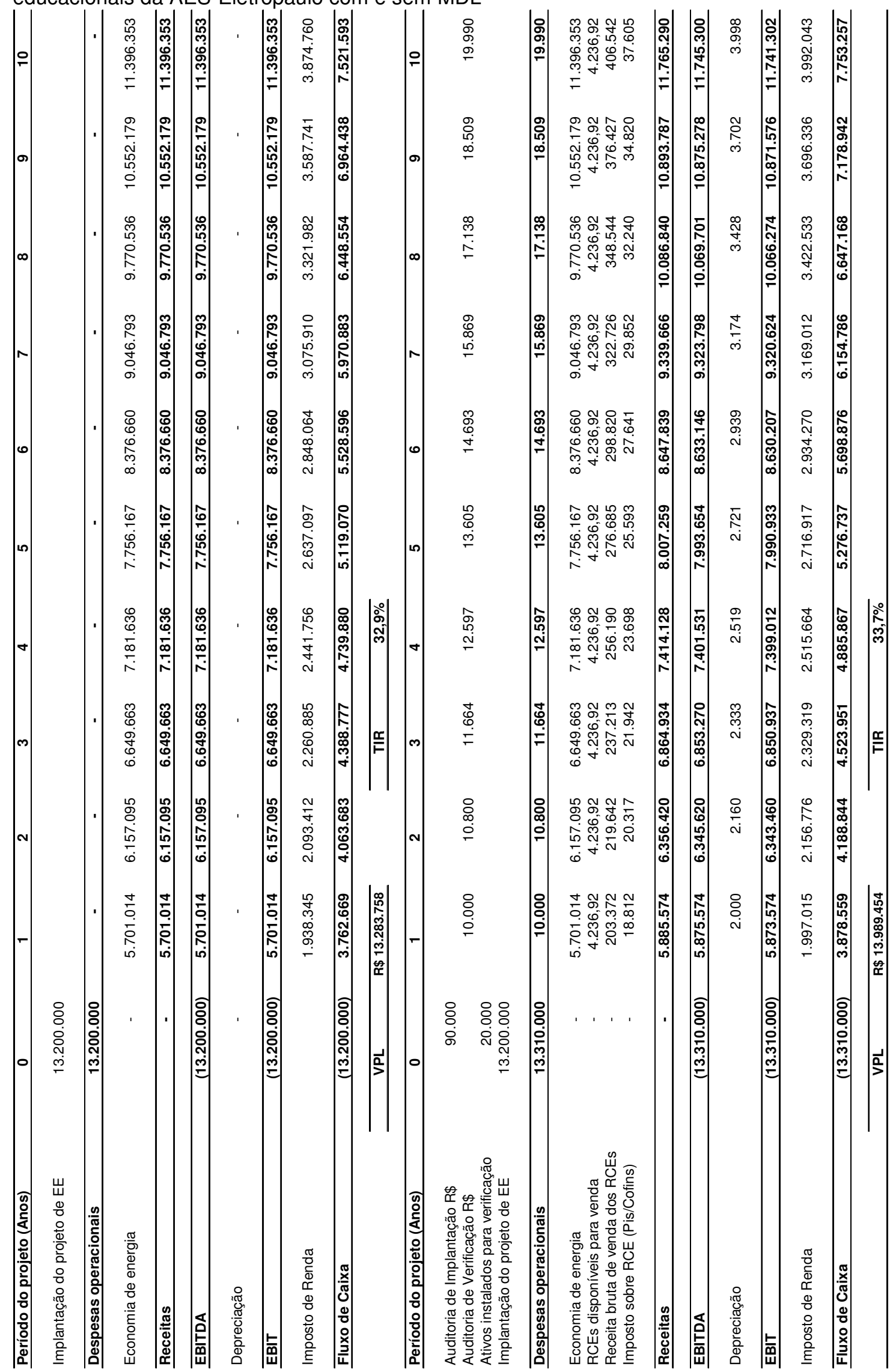

Fonte: Elaboração própria 


\section{5 - Limite de viabilidade para obtenção de créditos de carbono}

Analisando o item anterior foi possível avaliar que os projetos de menor porte têm o seu desempenho financeiro reduzido com a inserção do projeto de MDL sobre o projeto original de eficiência energética, porém os projetos de maior porte têm apresentado um aumento no seu desempenho financeiro.

Buscando obter uma conclusão mais precisa sobre a viabilidade de projetos, este item apresenta o limite a partir do qual um projeto de eficiência energética possui o seu desempenho financeiro aumentado com a inserção do projeto de MDL.

Como a economia de energia é o parâmetro fundamental neste tipo de projeto, pois é ela que multiplicada pelo fator de emissão determina a redução de emissões de GEE, esta análise considera projetos com diversos valores de economia de energia. A faixa de economia de energia analisada é de $1.000 \mathrm{MWh}$ à $15.000 \mathrm{MWh}$ com cálculos de 1.000 em 1.000 MWh. Para que seja possível analisar de forma igualitária os projetos com diferentes valores de economia de energia, é necessário inserir um valor proporcional de investimento e de redução de demanda.

Januzzi (2007 et. al.) apresenta o resumo dos projetos de eficiência energética realizados nos ciclos 2005/2006 e 2006/2007 pelas distribuidoras de energia elétrica do Brasil.

\begin{tabular}{|l|c|c|c|c|}
\hline \multicolumn{1}{|c|}{ Tipo de Projeto } & $\begin{array}{c}\text { Investimento } \\
\text { Apropriado } \\
(\mathbf{R} \$)\end{array}$ & $\begin{array}{c}\text { Investimento } \\
\text { Apropriado } \\
(\%)\end{array}$ & $\begin{array}{c}\text { Energia } \\
\text { Economizada } \\
(\mathbf{M W h} / \mathbf{a n o})\end{array}$ & $\begin{array}{c}\text { Demanda } \\
\text { Evitada } \\
\text { (kW) }\end{array}$ \\
\hline Residencial & $304.857 .404,19$ & 63,7 & 511.502 & 183.488 \\
\hline Poderes Públicos & $58.054 .933,90$ & 12,1 & 64.786 & 16.525 \\
\hline Industrial & $55.117 .547,69$ & 11,5 & 178.735 & 25.992 \\
\hline Serviços Públicos & $26.355 .705,27$ & 5,5 & 38.899 & 7.706 \\
\hline Comércio e Serviços & $22.862 .519,95$ & 4,8 & 27.067 & 6.103 \\
\hline Rural & $6.389 .850,12$ & 1,3 & 7.634 & 3.597 \\
\hline Aquecimento Solar & $4.623 .665,12$ & 1,0 & 1.355 & 1.335 \\
\hline Total & $478.261 .626,24$ & 100 & 829.979 & 244.746 \\
\hline
\end{tabular}

Figura 15 - Resumo dos projetos do PEE nos ciclos 2005/2006 e 2006/2007 Fonte: Januzzi (2007 et. al.) 
Em função dos valores apresentados na figura 15 abrangerem uma grande variedade de tipos de projetos e empresas executantes, é possível extrair um valor médio e representativo de investimento e de redução de demanda que seja proporcional à economia de energia.

Para calcular as relações médias foram excluídos os valores dos setores residencial, rural e aquecimento solar, pelo fato de possuírem aplicações específicas que poderiam poluir os valores médios calculados. Portanto, os quatro setores resultantes formaram a tabela 8 .

Tabela 8 - Relação média entre investimento e economia de energia e entre investimento e redução de demanda em projetos de eficiência energética

\begin{tabular}{|c|c|c|c|c|c|c|}
\hline Tipo de projeto & & Investimento & Energia/ano & Demanda & $\mathrm{R} \$ / \mathrm{MWh} /$ ano & $\mathrm{R} \$ / \mathrm{kW}$ \\
\hline Poderes Públicos & $\mathrm{R} \$$ & $58.054 .933,90$ & 64.786 & 16.525 & 896,1 & $3.513,2$ \\
\hline Industrial & $\mathrm{R} \$$ & $55.117 .547,69$ & 178.735 & 25.992 & 308,4 & $2.120,6$ \\
\hline Serviço público & $\mathrm{R} \$$ & $26.355 .705,27$ & 38.899 & 7.706 & 677,5 & $3.420,2$ \\
\hline \multirow[t]{2}{*}{ Comércio e Serviços } & $\mathrm{R} \$$ & $22.862 .519,95$ & 27.067 & 6.103 & 844,7 & $3.746,1$ \\
\hline & & & & Média & 681,7 & $3.200,0$ \\
\hline
\end{tabular}

Fonte: Elaboração própria adaptado de Januzzi (2007 et. al.)

As simulações de análise da viabilidade consideram 15 valores de economia de energia iniciando em 1.000 MWh e finalizando em 15.000 MWh com etapas de 1.000 em 1.000 MWh. O valor do investimento é obtido multiplicando cada valor de economia de energia por 681,7 e o valor de redução de demanda é obtido dividindo o investimento calculado por 3.200.

Os valores calculados do VPL e da TIR são apresentados de forma gráfica na qual o eixo $\mathrm{X}$ corresponde aos valores de economia de energia e o eixo $\mathrm{Y}$ corresponde ao valor do VPL ou da TIR, dependendo do gráfico analisado.

Em cada gráfico são apresentadas duas linhas, na qual a linha vermelha corresponde aos valores calculados para o projeto de eficiência energética original e a linha azul corresponde aos valores calculados para o projeto de eficiência energética acrescido das receitas e despesas do projeto de MDL.

O cruzamento dos dois gráficos corresponde ao ponto de equilíbrio a partir do qual o projeto de MDL, inserido sobre o projeto de eficiência energética, passa a aumentar o seu desempenho financeiro.

Como o fator de emissão e o preço da tonelada de carbono influenciam significativamente no desempenho financeiro do projeto, este trabalho criou três 
cenários com valores diferentes para estes dois parâmetros, devido a variações que eles podem sofrer.

Analisando a variação do ponto de equilíbrio destes três cenários será possível confirmar a influência do fator de emissão e do preço da tonelada de carbono no desempenho financeiro dos projetos.

\subsection{1 - Cenário de Referência}

Para realizar as análises do cenário de referência foram utilizadas as premissas apresentadas no item 5.4 deste trabalho, repetidas em 15 planilhas distintas (conforme modelo apresentado em detalhes no Anexo A) nas quais é alterada somente a quantidade de energia economizada. Os valores de investimento e redução de demanda são obtidos com a aplicação da relação média calculada na tabela 8. Os resultados são apresentados nos gráficos 1 e 2.

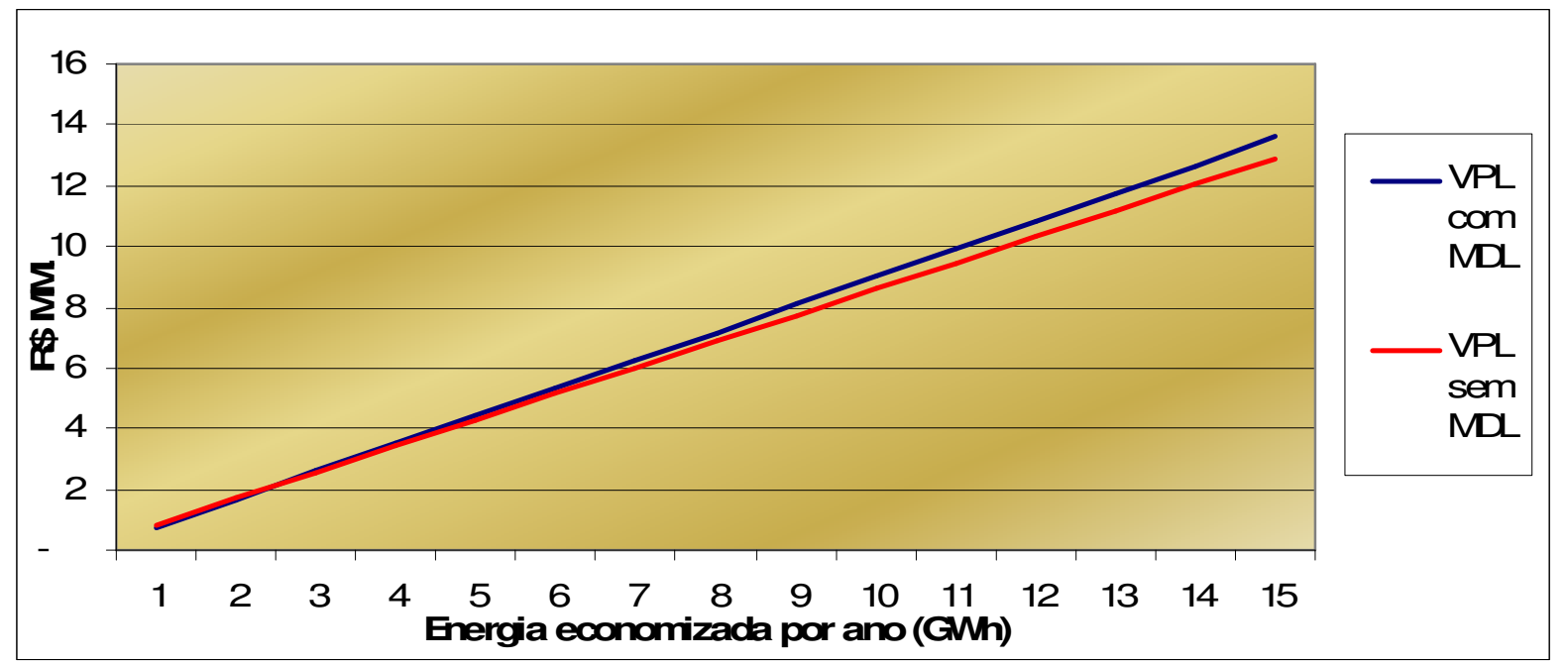

Gráfico 1 - VPL de projetos de eficiência energética de 1 a 15 GWh de economia com e sem o projeto de MDL no cenário de referência

Fonte: Elaboração própria 


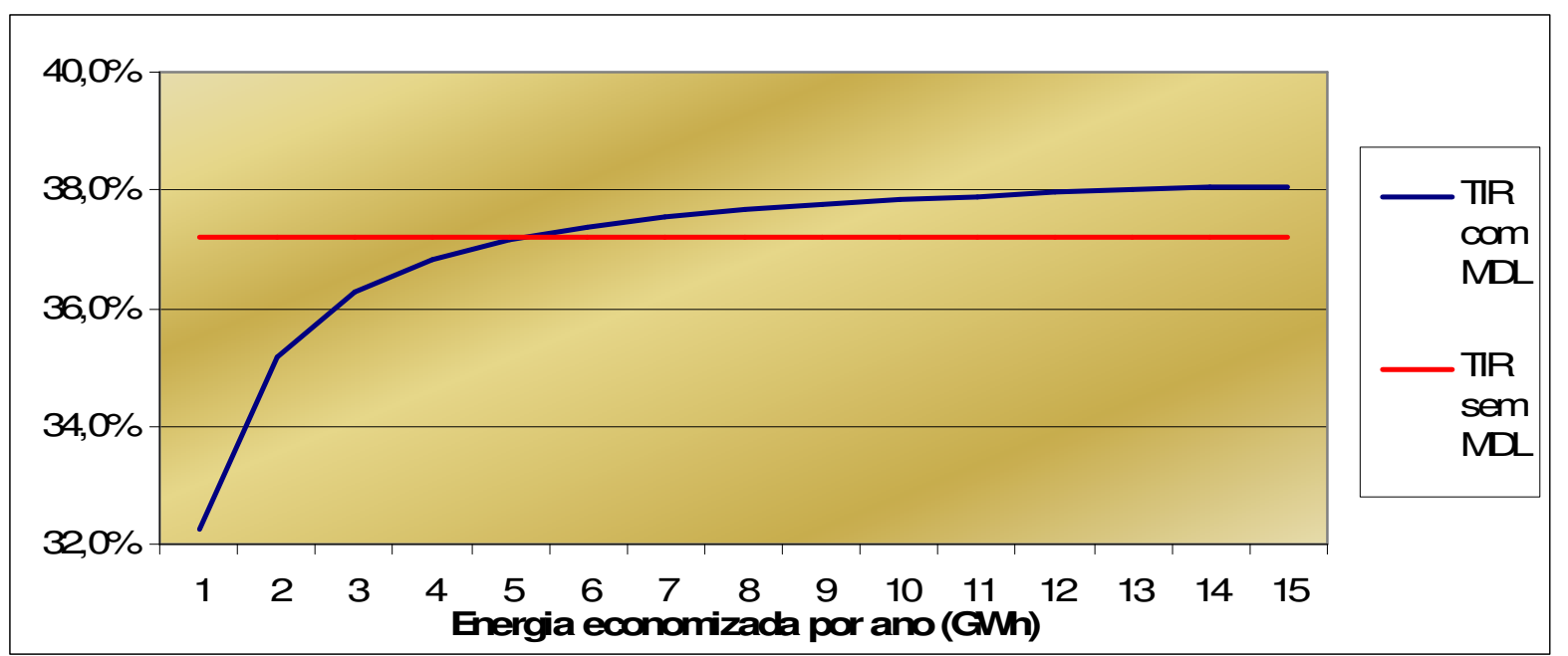

Gráfico 2 - TIR de projetos de eficiência energética de 1 a 15 GWh de economia com e sem o projeto de MDL no cenário de referência

Fonte: Elaboração própria

Analisando os gráficos é possível notar que os projetos com valores menores de economia de energia, apresentam o seu desempenho financeiro reduzido com a inserção do projeto de MDL sobre o projeto eficiência energética original. Entretanto, a situação se inverte em projetos com valores mais elevados de economia de energia.

O ponto de equilíbrio no gráfico do VPL (gráfico 1) acontece em um projeto com 2.700 MWh de economia de energia, sendo que somente acima deste valor ocorre o aumento do VPL com a inserção das receitas e despesas do projeto de MDL sobre o projeto de eficiência energética original.

No caso da TIR o ponto de equilíbrio do gráfico 2 ocorre em uma economia de energia de $5.300 \mathrm{MWh}$, acima do qual a TIR do projeto de eficiência energética apresenta uma evolução com a inserção do projeto de MDL.

\subsection{2 - Cenário Pessimista}

Para que seja possível analisar algumas variáveis de parâmetros foi criado um cenário pessimista, que adota as premissas já explanadas anteriormente com exceção de dois parâmetros, o fator de emissão e o preço da tonelada de carbono. 
Como o fator de emissão é definido através da metodologia de determinação da linha de base, a simples alteração do ano base dos dados coletados pode gerar um cálculo diferente do fator de emissão. O emprego de uma nova metodologia ou de uma metodologia diferente da ACM0002, utilizada pelo Centro de Gestão e Estudos Estratégicos (2008) que serviu de base para este trabalho, também pode acarretar em um valor diferente do fator de emissão.

Para o cenário pessimista deste trabalho é utilizado o fator de emissão de 0,118 $\mathrm{tCO}_{2} / \mathrm{MWh}$, calculado pelo Centro de Gestão e Estudos Estratégicos (2008, p. 158) para o submercado norte/nordeste do Sistema Interligado Nacional.

O preço da tonelada de carbono, que no cenário de referência havia sido o valor comercializado no leilão ocorrido em São Paulo no ano de 2008, para o cenário pessimista foi utilizado o valor de €16,2, comercializado no leilão ocorrido também em São Paulo no ano de 2007.

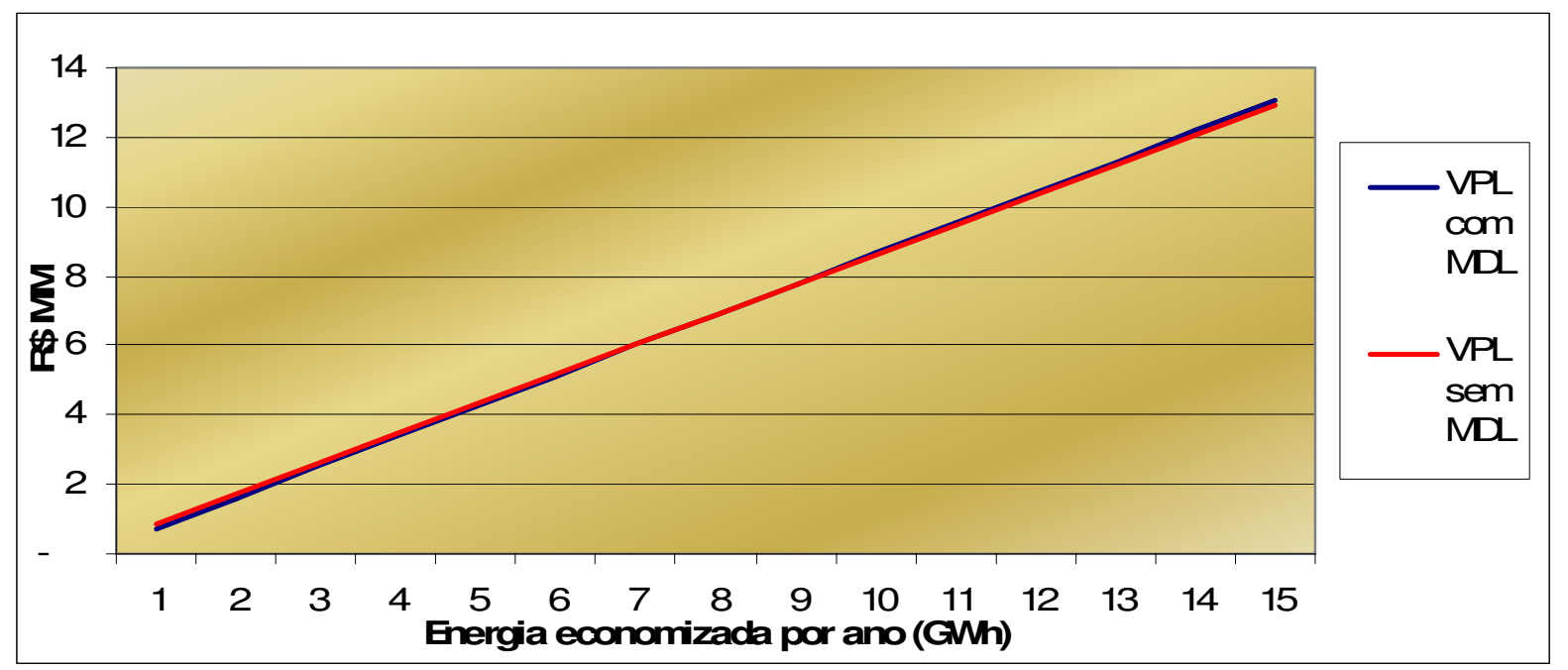

Gráfico 3 - VPL de projetos de eficiência energética de 1 a 15 GWh de economia com e sem o projeto de MDL no cenário pessimista Fonte: Elaboração própria 


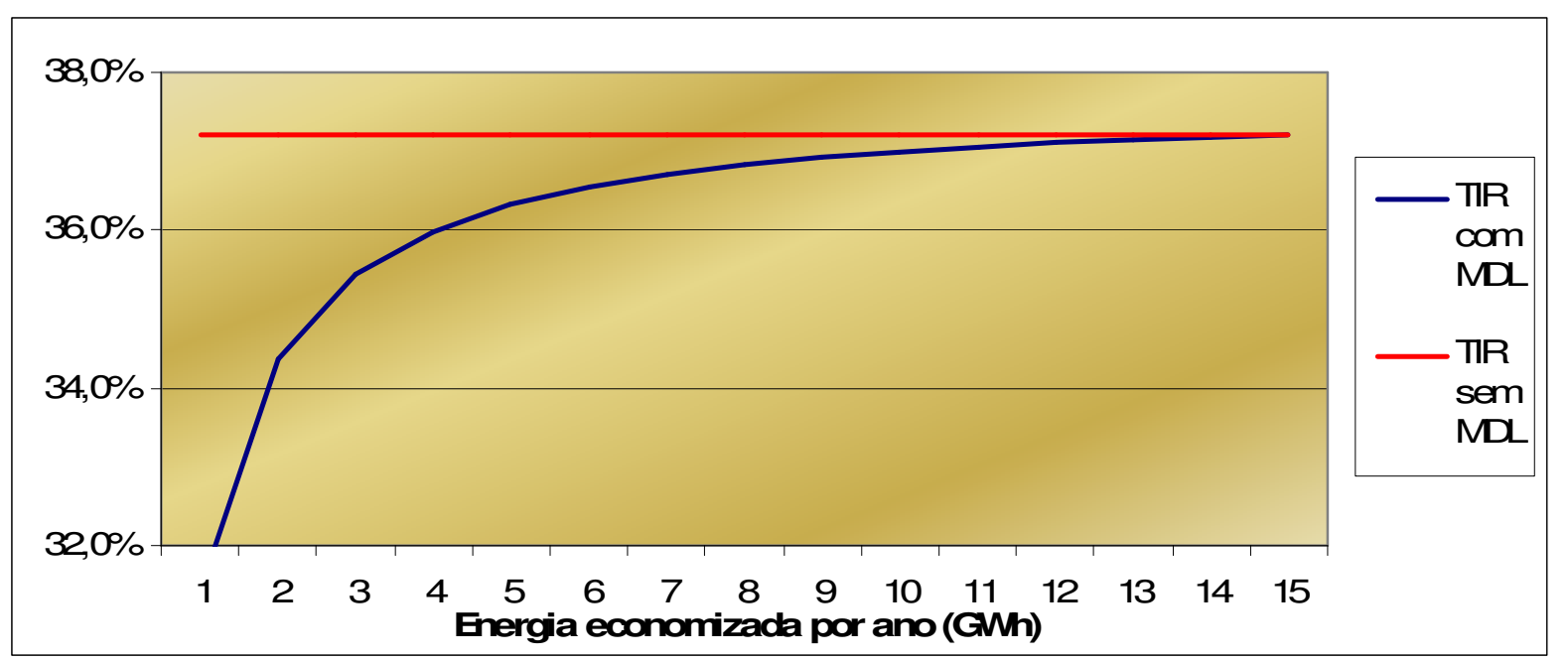

Gráfico 4 - TIR de projetos de eficiência energética de 1 a 15 GWh de economia com e sem o projeto de MDL no cenário pessimista

Fonte: Elaboração própria

É possível observar neste cenário que o desempenho financeiro do projeto de eficiência energética, com a inserção das receitas e despesas advindas do projeto de MDL, ficou muito prejudicado refletindo no elevado ponto de equilíbrio dos gráficos.

O ponto de equilíbrio do gráfico do VPL (gráfico 3) ocorre em um projeto de 7.700 MWh de economia de energia. O ponto de equilíbrio do gráfico da TIR (gráfico 4) ocorre em um projeto de $14.700 \mathrm{MWh}$ de economia de energia.

\subsection{3 - Cenário Otimista}

Assim como no cenário pessimista, o cenário otimista utiliza as premissas já adotadas no item 5.4, alterando somente o fator de emissão e o preço da tonelada de carbono.

O site do Ministério da Ciência e Tecnologia, consultado em 01/11/08, mantinha disponível para consulta a margem de construção e a margem de operação do Sistema Interligado Nacional de forma horária, mensal e suas respectivas médias até o mês de agosto de 2008.

O item 5.2.1 deste trabalho aponta que a obtenção do fator de emissão ocorre pela média ponderada destas duas margens. Este cenário considerou a situação mais 
favorável, calculando a média dos últimos 12 meses somente da margem de operação, portanto de setembro de 2007 a agosto de 2008, sendo o fator de emissão médio deste período de $0,4745 \mathrm{tCO}_{2} / \mathrm{MWh}$ conforme tabela 9 .

A abrangência de 12 meses da tabela 9 permite que a média calculada considere a variabilidade hidrológica existente no país, que acarreta na entrada em operação de usinas térmicas, mais poluidoras, em determinada época do ano

Tabela 9 - Fator de emissão médio no Sistema Interligado Nacional em $\mathrm{tCO}_{2} / \mathrm{MWh}$ considerando somente a margem de operação

\begin{tabular}{ccccccccccccc}
\hline set/07 & out $/ 07$ & nov/07 & dez/07 & jan/08 & fev/08 & mar/08 & abr/08 & mai/08 & jun/08 & jul/08 & ago/08 & Média \\
\hline 0,3550 & 0,3774 & 0,4059 & 0,4865 & 0,5727 & 0,6253 & 0,5794 & 0,4529 & 0,4579 & 0,5180 & 0,4369 & 0,4258 & $\mathbf{0 , 4 7 4 5}$ \\
\hline
\end{tabular}

Fonte: Elaboração própria adaptado de MINISTÉRIO DA CIÊNCIA E TECNOLOGIA - MCT, 2008b

Este cenário também considera uma elevação no preço de venda da tonelada de carbono proporcional à elevação apresentada entre 2007 e 2008. Em 2007 o preço do crédito foi comercializado por $€ 16,2$ e em 2008 o preço foi de $€ 19,2$, portanto um aumento de $18,5 \%$, considerando esta mesma proporção de aumento sobre o valor de 2008 obtém-se o preço de €22,7.

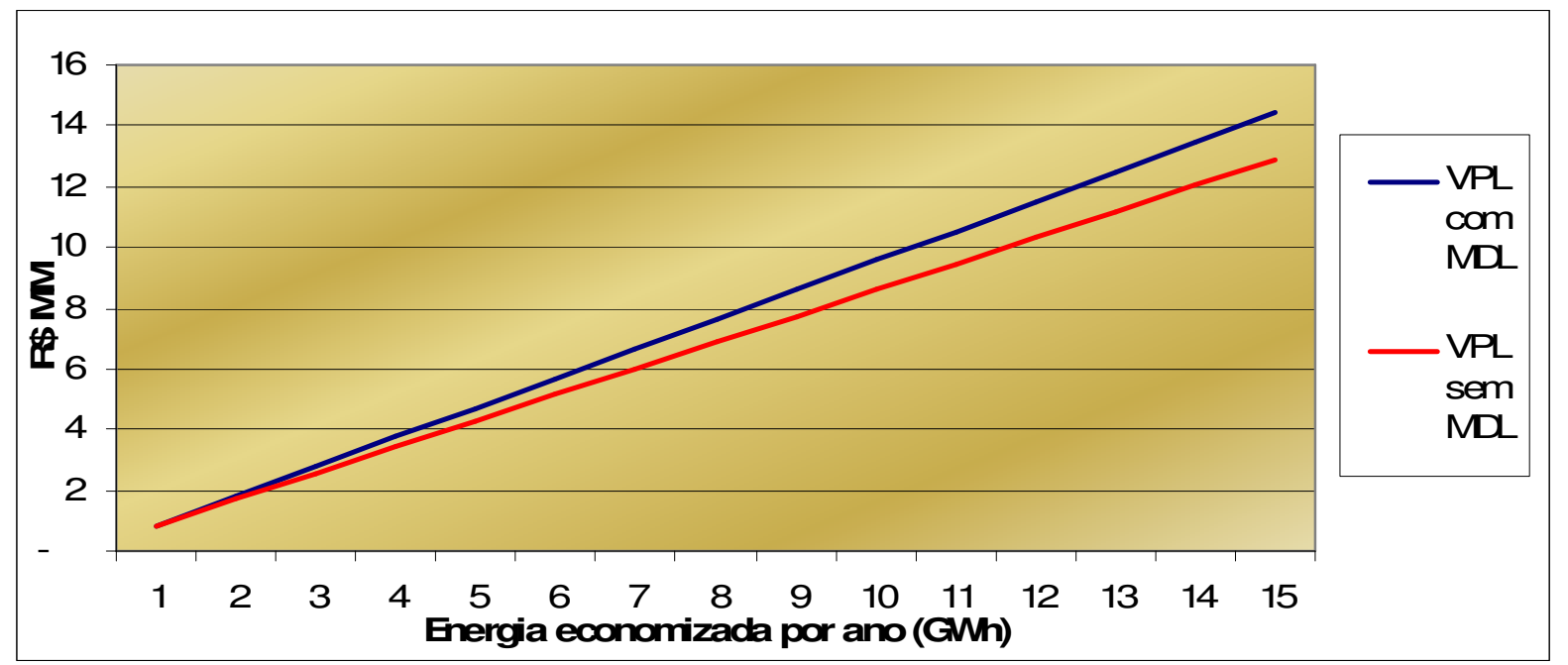

Gráfico 5 - VPL de projetos de eficiência energética de 1 a 15 GWh de economia com e sem o projeto de MDL no cenário otimista

Fonte: Elaboração própria 


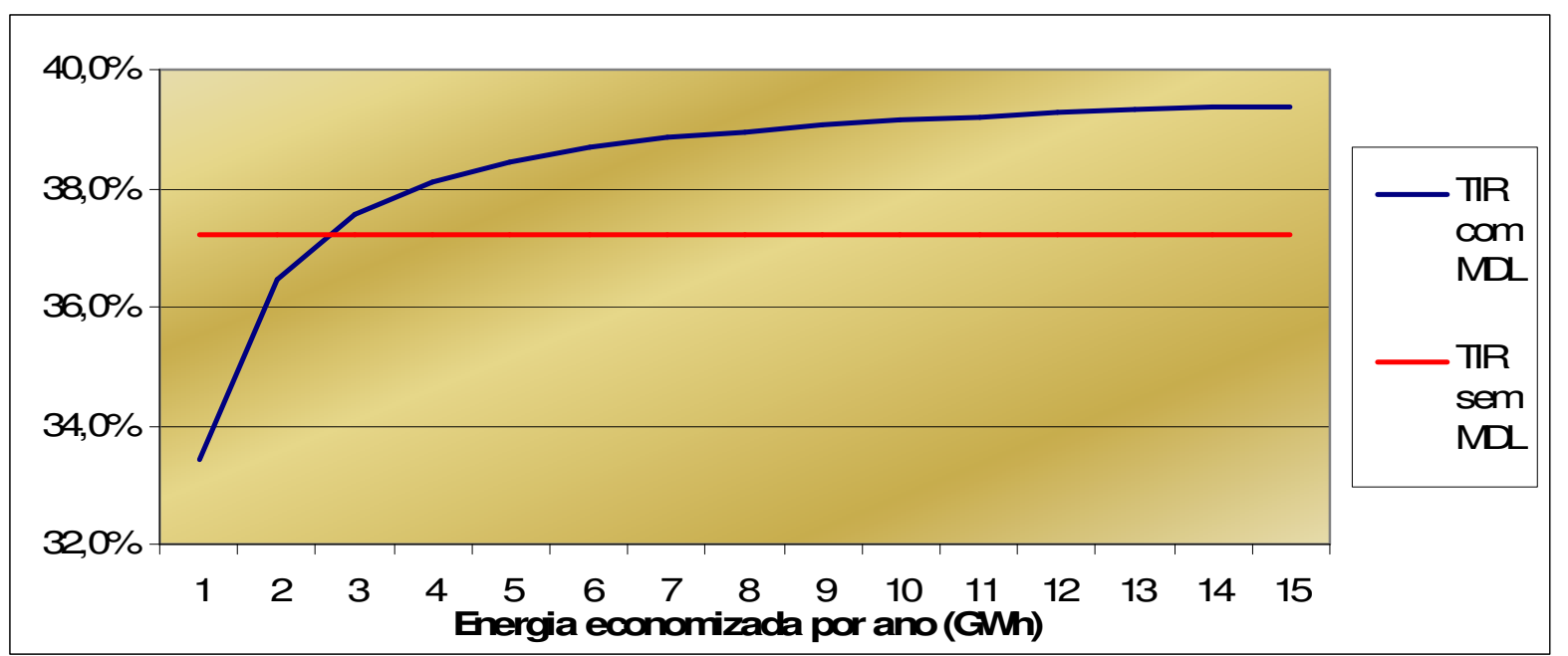

Gráfico 6 - TIR de projetos de eficiência energética de 1 a 15 GWh de economia com e sem o projeto de MDL no cenário otimista

Fonte: Elaboração própria

Neste cenário os pontos de equilíbrio dos gráficos ocorrem com valores de economia de energia bem mais reduzidos. O ponto de equilíbrio do gráfico do VPL (gráfico 5) ocorre em um projeto de $1.400 \mathrm{MWh}$ de economia de energia. O ponto de equilíbrio do gráfico da TIR (gráfico 6) ocorre em um projeto de 2.600 MWh de economia de energia.

\section{6 - Análise da viabilidade com extrapolação de parâmetros}

Os cenários estudados no item 5.5 consideram a variação de alguns parâmetros dentro de limites que podem ser alcançados com um elevado índice de probabilidade.

Este item simula uma grande variabilidade em três parâmetros de elevada influência sobre o resultado da análise, porém que podem ocorrer com um índice de probabilidade pequeno.

Aproveitando a modelagem utilizada nos itens anteriores, alguns parâmetros são extrapolados, com o intuito de se avaliar o seu impacto sobre o desempenho financeiro do projeto de eficiência energética com e sem o projeto de MDL. 
5.6.1 - Redução dos custos com auditoria

Os custos referentes às auditorias de implantação e verificação correspondem a valores representativos dentro dos projetos de eficiência energética, principalmente para os projetos de pequeno porte. $O$ item 5.4.1 estudou um projeto com investimento de $R \$ 558.160,11$, inserindo as despesas do projeto de MDL, 0 investimento se eleva em $R \$ 120.000,00$ (conforme estudado no item 5.4), correspondendo a $21,5 \%$ do valor total do projeto de eficiência energética.

Como os projetos de eficiência energética possuem características similares, os custos de auditoria podem ser compartilhados, com o intuito de reduzir o impacto individual em cada projeto.

A partir desta premissa foi considerada uma redução de $50 \%$ nos custos da auditoria de implantação, nos ativos de verificação e na auditoria de verificação. As demais premissas são similares ao cenário de referência.

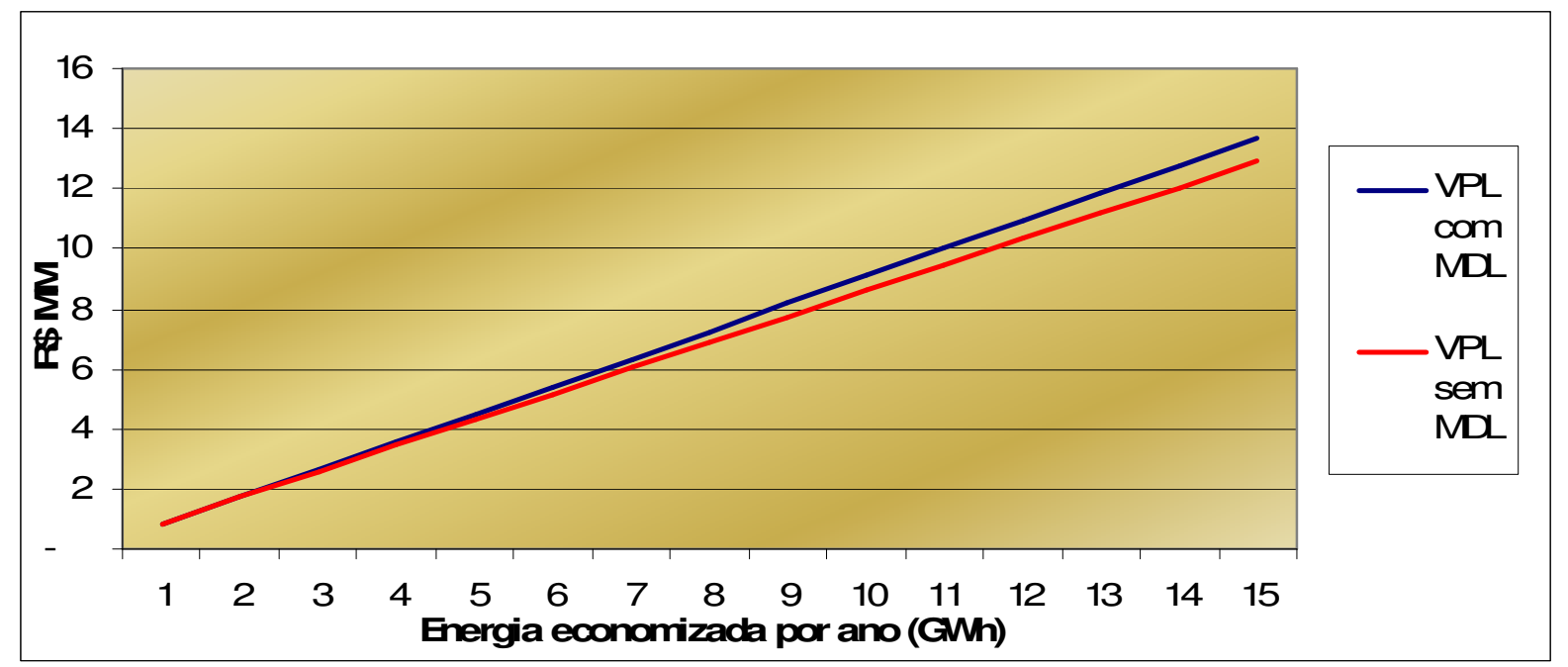

Gráfico 7 - VPL de projetos de eficiência energética de 1 a 15 GWh de economia com e sem o projeto de MDL considerando $50 \%$ de redução nos custos das auditorias Fonte: Elaboração própria 


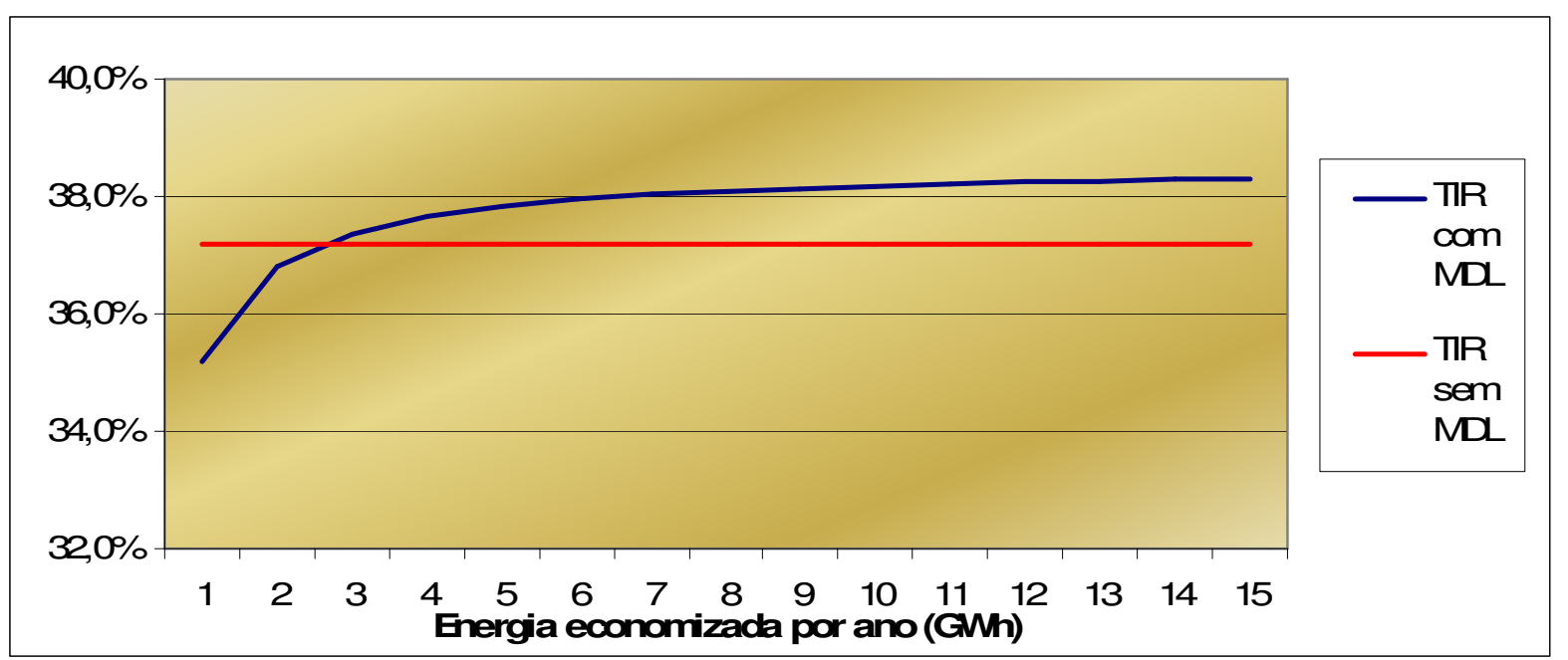

Gráfico 8 - TIR de projetos de eficiência energética de 1 a 15 GWh de economia com e sem o projeto de MDL considerando $50 \%$ de redução nos custos das auditorias

Fonte: Elaboração própria

O ponto de equilíbrio dos gráficos ocorre em projetos com valores de economia de energia inferiores ao cenário de referência. O ponto de equilíbrio do VPL (gráfico 7) ocorre a $1.400 \mathrm{MWh}$ de economia de energia contra 2.700 MWh do cenário de referência e o ponto de equilíbrio da TIR ocorre em 2.600 MWh de economia de energia em relação a 5.300 MWh do cenário de referência.

\subsection{2 - Aumento do preço do crédito de carbono}

Como ainda não estão definidas quais serão as metas de redução de emissão dos GEE após 2012 e também está sob discussão se os países em desenvolvimento passarão a possuir metas obrigatórias de redução de emissão, o preço do crédito de carbono no mercado internacional pode sofrer grande influência destas decisões.

Caso seja definido na reunião da Conferência das Partes, que ocorrerá em Copenhague no final de 2009, uma elevação do percentual obrigatório de redução de emissões, aumentará a procura pelas RCEs e por conseqüência, poderá haver uma elevação do preço da tonelada de carbono.

Outra variável que pode impactar significativamente o preço da tonelada de carbono, seria a ratificação do Protocolo de Quioto pelo Estados Unidos. O Presidente George 
Bush já havia declarado publicamente que não o faria, porém o novo Presidente Barack Obama, que assume em 2009, poderia vir a ratificá-lo.

Souza (2007, p. 242) prevê que entre os anos de 2008 e 2012 o preço da tonelada de carbono estaria entre $€ 30,00$ e $€ 40,00$. Considerando que este preço se eleve a $€ 40,00$ e mantidos todos os demais parâmetros utilizados no cenário de referência, os gráficos do VPL e da TIR se apresentariam da seguinte forma.

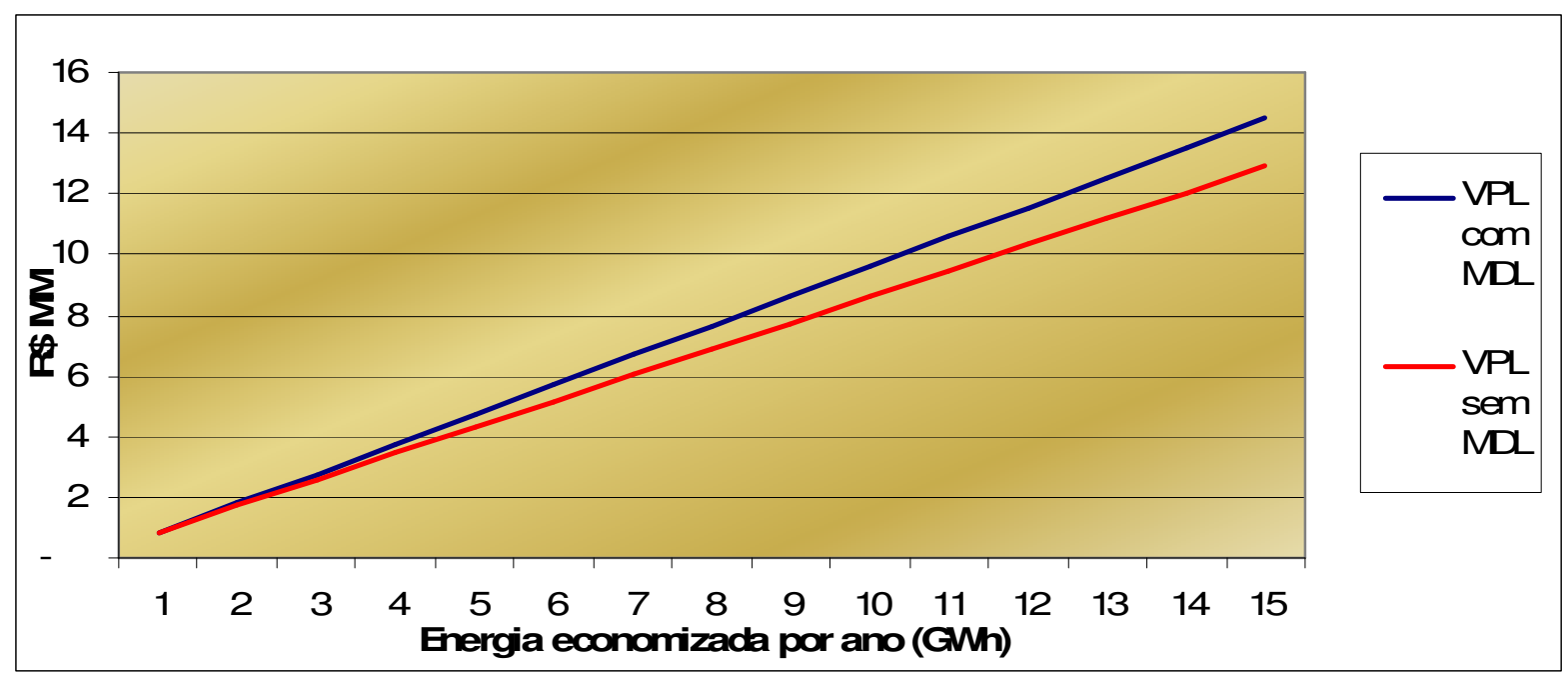

Gráfico 9 - VPL de projetos de eficiência energética de 1 a 15 GWh de economia com e sem o projeto de MDL considerando o preço de venda da RCE de $€ 40,00$ Fonte: Elaboração própria

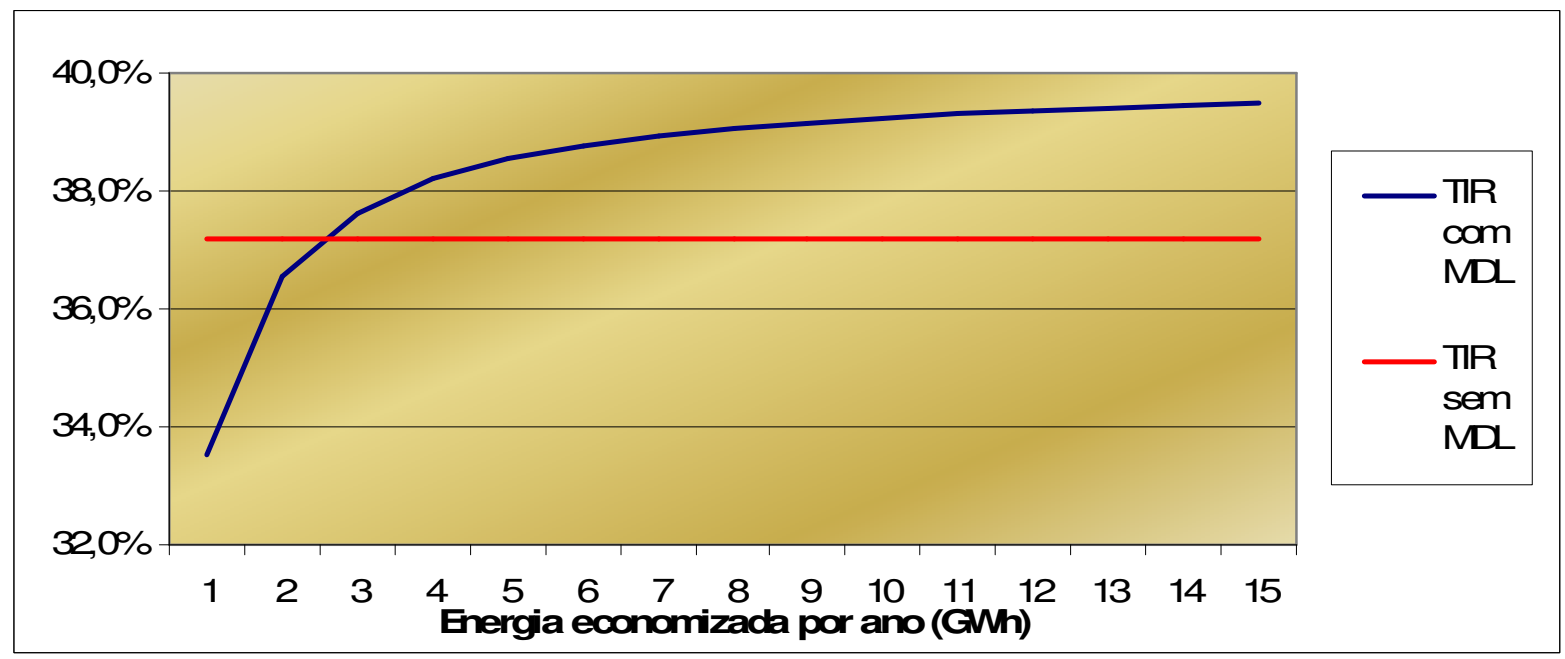

Gráfico 10 - TIR de projetos de eficiência energética de 1 a 15 GWh de economia com e sem o projeto de MDL considerando o preço de venda da RCE de $€ 40,00$

Fonte: Elaboração própria 
Nestas condições o ponto de equilíbrio dos gráficos corresponde a um projeto de 1.300 MWh de economia de energia para o VPL (gráfico 9) e no caso da TIR (gráfico 10) corresponde a um projeto de $2.500 \mathrm{MWh}$ de economia de energia.

\subsection{3 - Aumento do fator de emissão}

O fator de emissão é um parâmetro muito importante para esta modelagem, pois seria inócuo um projeto economizar muita energia se esta economia não representasse uma grande redução de emissão de GEE, o que ocorreria se o fator de emissão fosse muito baixo.

Os últimos leilões de geração de energia no Brasil têm apresentado predominância de usinas térmicas, o que acarreta um fator de emissão mais elevado, em relação à predominância de usinas hidroelétricas existentes no país.

De acordo com Freire (2008), considerando toda a energia nova prevista para início de suprimento entre janeiro de 2008 a janeiro de 2013, 63\% é de origem térmica, sendo em sua maior parte produzida a partir de óleo e carvão, que são fontes de energia muito poluidoras.

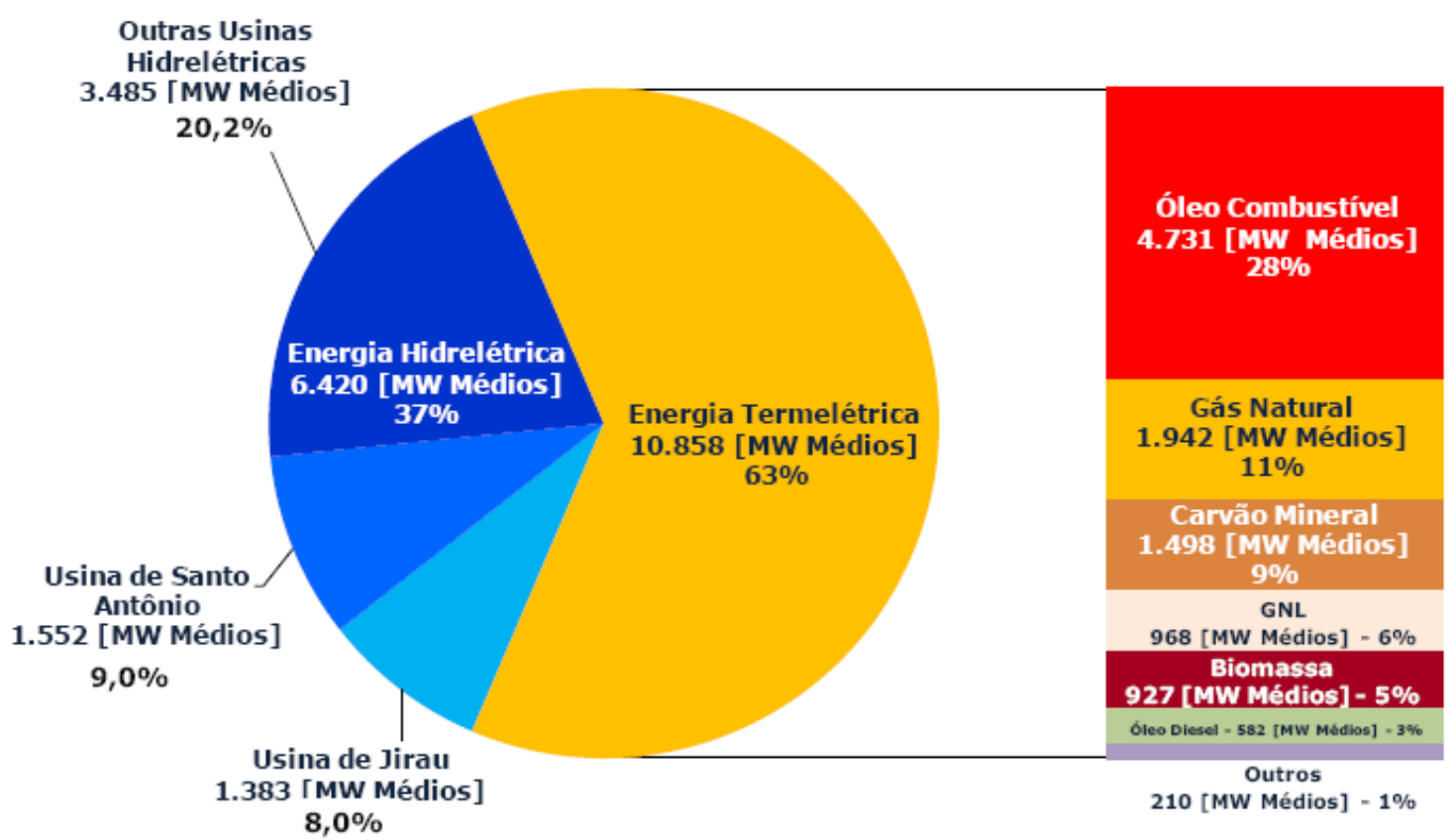

Figura 16 - Energia negociada nos leilões de novas usinas com entrada em operação entre janeiro de 2008 e janeiro de 2013

Fonte: FREIRE, 2008 
De acordo com Goldemberg (2003, p. 105) o fator de emissão de uma usina movida a óleo ou carvão pode ultrapassar a $1 \mathrm{tCO}_{2} / \mathrm{MWh}$. A análise de viabilidade realizada neste item considera o fator de emissão como sendo de $1 \mathrm{tCO}_{2} / \mathrm{MWh}$.

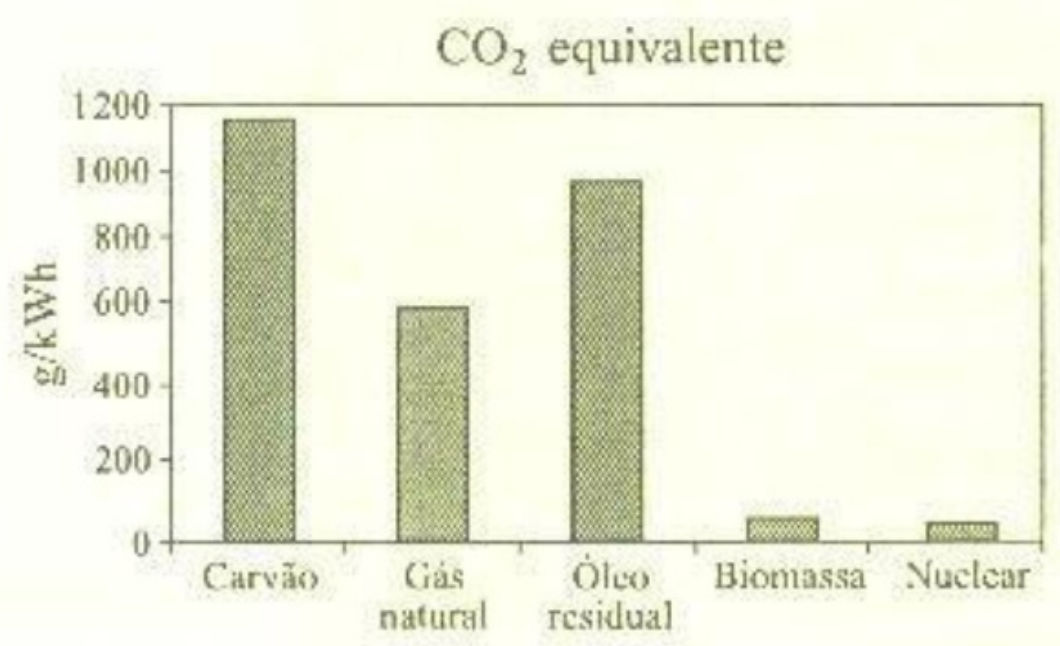

Figura 17 - Emissões de $\mathrm{CO}_{2}$ equivalente de usina de energia elétrica por tipo de fonte Fonte: GOLDEMBERG, 2003

Esta simulação também é válida para o caso em que a economia de energia ocorra em uma instalação que seja suprida através de uma fonte puramente térmica, como por exemplo, no Sistema Isolado em algumas localidades da Região Norte do país. A mesma aplicação também é válida para algum outro país que possua uma matriz predominantemente térmica.

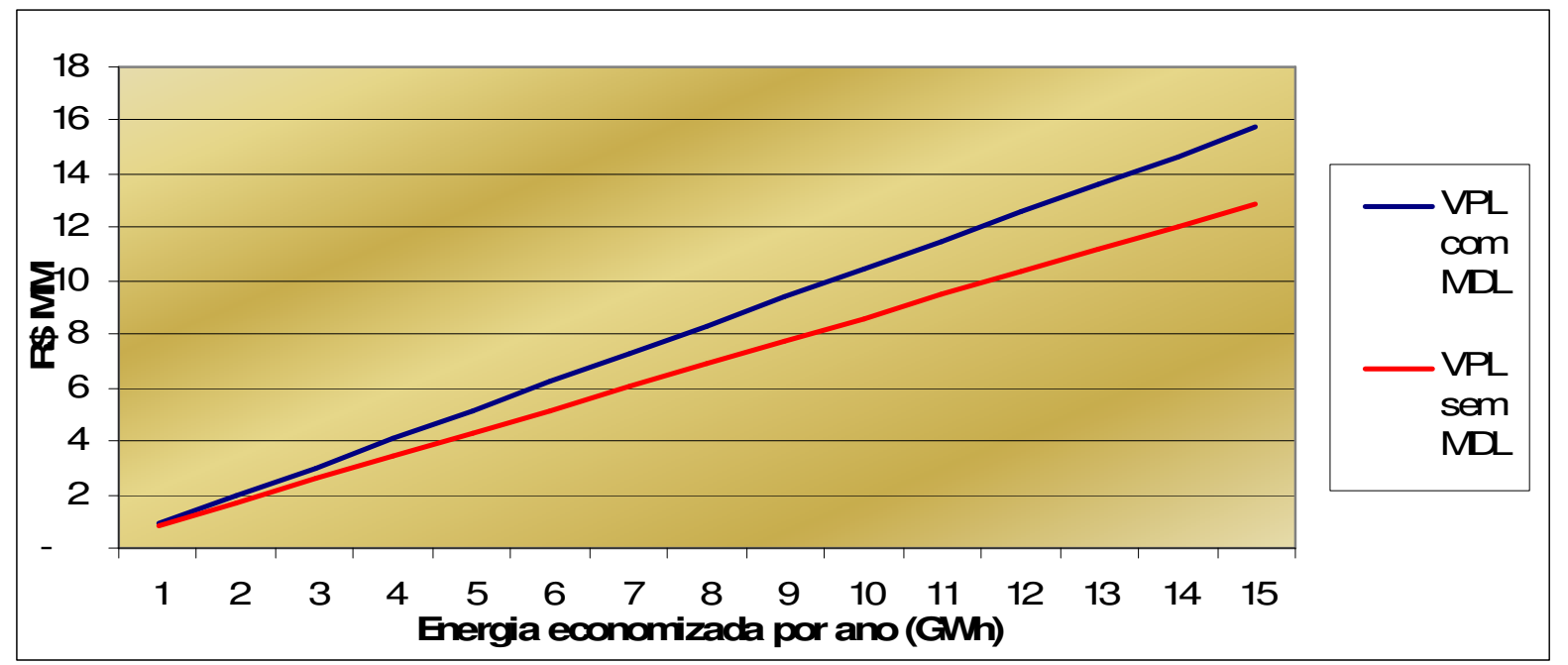

Gráfico 11 - VPL de projetos de eficiência energética de 1 a 15 GWh de economia com e sem o projeto de MDL considerando o fator de emissão de $1 \mathrm{tCO}_{2} / \mathrm{MWh}$

Fonte: Elaboração própria 


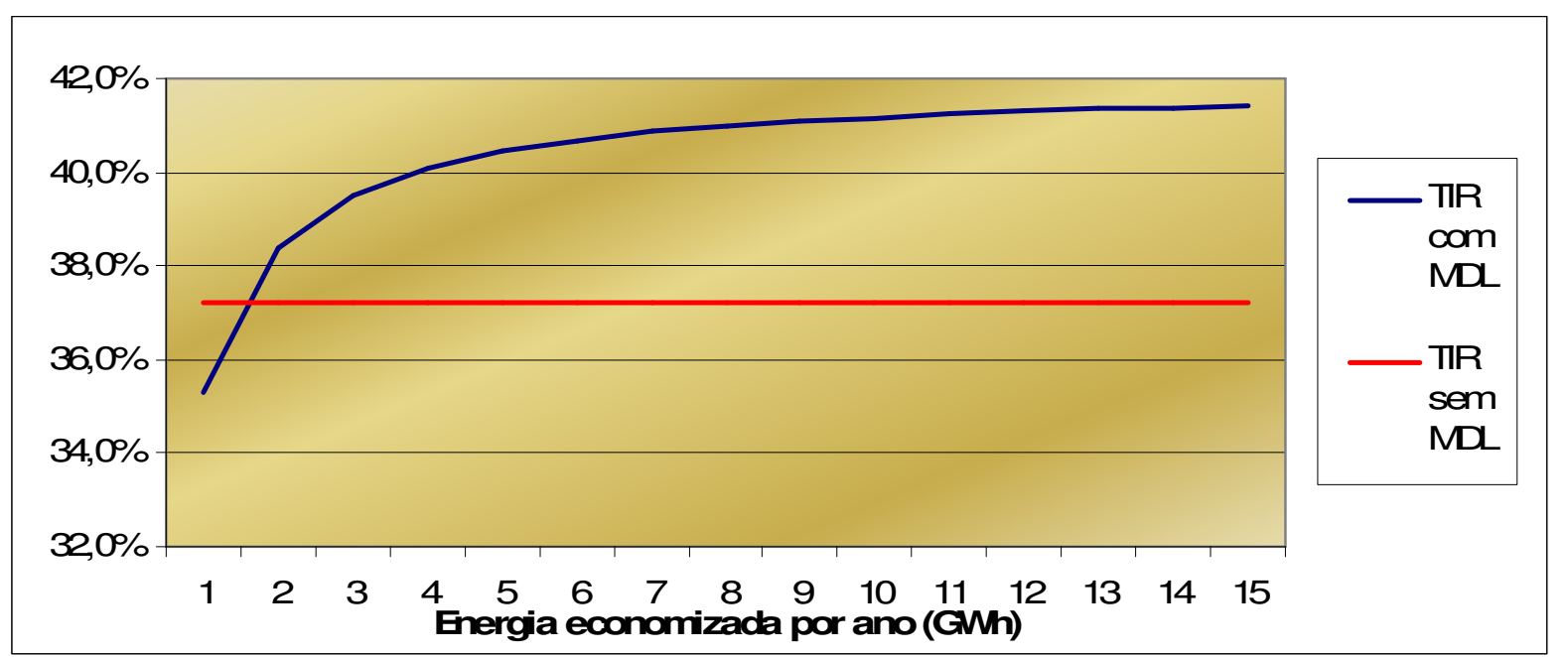

Gráfico 12 - TIR de projetos de eficiência energética de 1 a 15 GWh de economia com e sem o projeto de MDL considerando o fator de emissão de $1 \mathrm{tCO}_{2} / \mathrm{MWh}$

Fonte: Elaboração própria

O ponto de equilíbrio no gráfico 11 (VPL) ocorre em um projeto de $800 \mathrm{MWh}$ de economia de energia, enquanto no gráfico 12 (TIR) ocorre em $1.500 \mathrm{MWh}$ de economia de energia. 


\section{6 - DISCUSSÃO}

Neste capítulo são discutidos os resultados apresentados nos itens 5.4, 5.5 e 5.6 deste trabalho. Estes resultados se referem ao desempenho financeiro de um projeto exclusivamente de eficiência energética, em relação ao desempenho deste mesmo projeto depois de inseridas as despesas e receitas do projeto de MDL.

Pode-se avaliar que acima dos pontos de equilíbrio apresentados nos gráficos, o desempenho financeiro do projeto apresenta uma evolução, entretanto, uma análise de viabilidade de projeto não considera somente o desempenho financeiro, mas também pondera os riscos associados. Alguns dos riscos associados à realização de um projeto de MDL são:

- Falta de liquidez das RCEs no mercado;

- Valor de venda da RCE abaixo do esperado;

- Demora da aprovação ou reprovação do projeto por parte da AND;

- Demora da aprovação ou reprovação do projeto por parte do Conselho Executivo da UNFCCC;

Portanto, a decisão por realizar ou não o projeto de MDL concomitantemente ao projeto de eficiência energética, deve ser avaliada comparando a evolução no desempenho financeiro do projeto com a inserção de riscos adicionais.

Outros fatores também podem influenciar na decisão, como aspectos relacionados à imagem da empresa associada a um projeto de MDL, metas corporativas, missão e visão da organização, dentre outros.

A partir da discussão apresentada neste trabalho, compete aos envolvidos na análise da viabilidade do projeto de eficiência energética ponderar se a evolução apresentada nos indicadores financeiros compensa os riscos adicionais do desenvolvimento de um projeto de MDL.

\section{1 - Discussão da aplicação da metodologia em casos reais}


Analisando os quatro projetos estudados no item 5.4 deste trabalho, é possível notar que o VPL de todos os projetos é positivo, isto demonstra que os projetos apresentam receitas superiores ao valor do capital investido. A TIR dos projetos originais de eficiência energética está dentro da faixa de $23 \%$ a $33 \%$, indicando que somente o projeto de eficiência energética já apresenta um bom desempenho financeiro (aproximadamente o dobro da taxa Selic).

O primeiro projeto estudado, de sistema de bombeamento e automação na SAMAE, apresentou redução tanto do VPL como da TIR após a inserção das despesas e receitas do projeto de MDL. A redução do VPL foi de $23 \%$ e a redução da TIR foi de 6,1 pontos percentuais.

Analisando o segundo projeto, do sistema de ar condicionado da Prefeitura de Recife, também é possível notar uma redução do VPL e da TIR, após a inserção do projeto de MDL sobre o projeto de eficiência energética. Neste caso a redução do VPL foi de $14,6 \%$ e a redução da TIR foi de 1,8 pontos percentuais.

O segundo projeto analisado possui um porte maior em relação ao primeiro, enquanto o segundo projeto economiza $757,1 \mathrm{MWh} / \mathrm{ano}$, o primeiro projeto analisado economiza 501,5 MWh anualmente. Também foi possível notar que a redução dos indicadores financeiros ocorreu em uma escala menor no segundo projeto em relação ao primeiro.

O terceiro projeto estudado, no item 5.4 deste trabalho, refere-se a um agrupamento de projetos de sistema de bombeamento da CPFL, e o quarto projeto estudado refere-se a outro agrupamento de projetos educacionais da AES-Eletropaulo. Nestes dois casos tanto o VPL como a TIR apresentam um aumento do desempenho financeiro do projeto de eficiência energética após a inserção do projeto de MDL.

Estes projetos possuem o seu porte como diferencial, o agrupamento de projetos da CPFL totaliza uma economia de energia de $6.951 \mathrm{MWh} / \mathrm{ano}$ e o agrupamento de projetos da AES-Eletropaulo totaliza uma economia anual de energia de 15.496 MWh.

É possível notar que os projetos de maior porte possuem o seu desempenho financeiro aumentado com a inserção do projeto de $\mathrm{MDL}$, em relação ao projeto original de eficiência energética, porém projetos de menor porte apresentam o efeito contrário. 
Este fato se deve ao custo das auditorias de implantação e verificação que não variam, ou variam muito pouco, em função do porte do projeto, portanto, gerando maior impacto em projetos pequenos.

Entretanto, apesar do aumento do desempenho financeiro nos dois maiores projetos, esta evolução não é muito significativa, o projeto da CPFL obteve uma elevação do VPL de 5,6\% e a TIR se elevou em 0,5 ponto percentual, após a inserção do projeto de MDL sobre o projeto original de eficiência energética.

O projeto da AES-Eletropaulo, mesmo com um valor de investimento elevado de $\mathrm{R} \$ 13,2$ milhões, e que economiza mais do que o dobro da energia do projeto da CPFL, apresenta um aumento do VPL de apenas 5,3\% e uma elevação da TIR de somente 0,8 ponto percentual, após a inserção do projeto de MDL sobre o projeto de eficiência energética.

Como estes projetos já apresentavam um desempenho financeiro atrativo, sob o ponto de vista de investimento, a inserção do projeto de MDL contribuiu ainda mais para este desempenho, entretanto, caso o projeto original de eficiência energética não apresentasse um bom desempenho financeiro, possivelmente não seria 0 projeto de MDL que o tornaria atrativo.

\section{2 - Discussão do limite de viabilidade}

A padronização da relação entre a economia de energia com o investimento e com a redução da demanda no item 5.5, é fundamental para que a análise possa proporcionar um resultado coerente quando comparado os três cenários criados.

Inicialmente foi criado um cenário de referência, com a aplicação dos parâmetros mais próximos da realidade atual, inclusive considerando valores similares aos utilizados em projetos de MDL já aprovados pela UNFCCC.

Considerando um projeto de eficiência energética que economize 10.000 MWh no cenário de referência, o VPL apresenta uma evolução de $\mathrm{R} \$$ 8.607.304,00 para $\mathrm{R} \$ 9.008 .916,00$, ou seja, um aumento de 4,6\%, após a inserção do projeto de MDL e a TIR aumenta de $37,2 \%$ para $37,8 \%$, ou seja, um aumento de 0,6 ponto percentual. 
Analisando o cenário pessimista os resultados apresentados nos gráficos evidenciam que qualquer projeto de eficiência energética com economia inferior a 15.000 MWh não apresenta viabilidade com a inserção do projeto de MDL.

Somente projetos com economia de energia superior a 15.000 MWh apresentam um aumento da TIR, entretanto, mesmo acima deste valor, se for projetada a tendência dos gráficos para uma economia de energia mais elevada, ambas as linhas se apresentam quase paralelas, o que significa que não há alteração significativa dos valores na simulação com e sem o projeto de MDL.

Apesar deste cenário não apresentar nenhuma viabilidade, não se pode deixar de considerar que as premissas adotadas para ele são as piores possíveis, considerando a regressão no preço do crédito de carbono e um fator de emissão muito abaixo do praticado em projetos brasileiros de MDL já aprovados pela UNFCCC.

Considerando um aumento no preço da tonelada de carbono e uma elevação no fator de emissão, o cenário otimista apresenta o ponto de equilíbrio dos gráficos em projetos de pequena economia de energia.

$\mathrm{Na}$ simulação realizada no item 5.5.3, o VPL de um projeto de $10.000 \mathrm{MWh}$ de economia por ano se eleva em $11 \%$ e a TIR se eleva em 1,9 pontos percentuais, após inseridas as receitas e despesas do projeto de MDL sobre o projeto de eficiência energética.

Neste cenário, se o projeto original de eficiência energética apresentar um desempenho financeiro próximo ao limite mínimo de viabilidade, definido pelas pessoas envolvidas na decisão de sua implantação, a inserção do projeto de MDL pode ser o diferencial que viabilize a sua realização.

\section{3 - Discussão da extrapolação de parâmetros}

O item 5.6 analisou algumas das premissas da modelagem sob a ótica de extrapolação de valores, porém sempre considerando patamares possíveis de serem alcançados em determinadas condições.

Primeiramente foi considerada a redução de $50 \%$ do preço das auditorias de implantação e verificação (item 5.6.1) devido ao compartilhamento e rateio da 
estrutura utilizada. Nesta situação o aumento do desempenho financeiro foi similar ao cenário de referência discutido no item anterior.

Em um projeto de $10.000 \mathrm{MWh}$ de economia de energia o VPL no projeto original de eficiência energética que é de $R \$ 8.607 .304,00$ aumenta para $R \$ 9.008 .916,00$, após a inserção do projeto de MDL, ou seja uma evolução de 5,5\%, e a TIR que é de $37,2 \%$ no projeto original de eficiência energética aumenta para $38,2 \%$ com a inserção do projeto de MDL, ou seja, um aumento de 1 ponto percentual.

A segunda análise (item 5.6.2) constituiu da extrapolação do preço de venda do crédito de carbono para um patamar de $€ 40,00$. O resultado foi um aumento significativo do desempenho financeiro do projeto com $M D L$ em relação ao projeto original de eficiência energética.

Considerando um projeto com economia de $10.000 \mathrm{MWh}$, o VPL evoluiu de $\mathrm{R} \$ 8.607 .304,00$ para $\mathrm{R} \$ 9.608 .304,00$ ou seja um aumento de $11,6 \%$ e a TIR aumentou de $37,2 \%$ para $39,2 \%$, ou seja, um aumento de 2 pontos percentuais após a inserção do projeto de MDL. Este resultado é muito próximo ao cenário otimista discutido no item anterior.

Circunstanciando o cenário de expansão de oferta de energia, o item 5.6.3 faz uma análise na condição de um elevado fator de emissão, da ordem de $1 \mathrm{tCO}_{2} / \mathrm{MWh}$. Esta simulação apresentou a maior evolução do desempenho financeiro estudado neste trabalho, após a inserção do projeto de MDL sobre o projeto de eficiência energética. Projetos que economizem 1.000 MWh já apresentam um VPL mais elevado com o projeto de MDL em relação ao projeto original de eficiência energética e no caso da TIR, projetos com economia superior a $1.500 \mathrm{MWh}$ já apresentam o seu desempenho financeiro aumentado.

Novamente tomando como referência um projeto que economize $10.000 \mathrm{MWh}$ ao ano, a evolução do VPL, após a inserção do projeto de $M D L$, é de $\mathrm{R} \$ 8.607 .304,00$ para $R \$ 10.438 .721,00$, ou seja um aumento de $21,3 \%$ e a TIR do mesmo projeto aumenta de $37,2 \%$ para $41,2 \%$, ou seja uma evolução de 4 pontos percentuais.

Nestas condições um projeto que esteja abaixo do seu limite de viabilidade, pode ter a inserção do projeto de MDL como fator preponderante pela decisão de sua implantação. 


\section{7 - CONCLUSÃO}

A partir das análises realizadas neste trabalho é possível concluir que a inserção das despesas e receitas referentes à obtenção de créditos de carbono (também chamado de projeto de MDL), influencia na viabilidade financeira de um projeto de eficiência energética. Esta influência pode aumentar ou diminuir o desempenho financeiro, dependendo principalmente do porte do projeto.

As análises realizadas em quatro projetos (item 5.4), financiados pelo PEE das distribuidoras de energia elétrica, indicam que os projetos originais de eficiência energética já apresentam valores de VPL positivos e TIR superior à taxa Selic, caracterizando serem bons projetos sob o ponto de vista financeiro.

A inserção do projeto de MDL fez com que os dois projetos de eficiência energética de menor porte, com economia de energia de 501,5 MWh e 757,1 MWh, apresentassem uma redução nos seus indicadores financeiros. A mesma análise realizada nos dois projetos de maior porte resultou em um aumento nestes indicadores, sendo que as economias anuais de energia destes projetos são de 6.951 MWh e 15.496 MWh.

Para identificar exatamente o montante de economia de energia a partir do qual um projeto de eficiência energética tem os seus indicadores financeiros aumentados a partir da inserção do projeto de MDL, foram criados três cenários de diferentes receitas advindas dos créditos de carbono.

De acordo com o cenário de referência (item 5.5.1), somente projetos de eficiência energética que economizem mais do que 5.300 MWh de energia elétrica por ano, apresentam os indicadores de desempenho financeiro TIR e VPL aumentados, após a inserção do projeto de MDL.

Neste cenário um projeto de eficiência energética que economize anualmente 10.000 MWh de energia elétrica, apresenta um aumento de 4,6\% no VPL e uma evolução da TIR de 0,6 ponto percentual.

Este trabalho também realizou análises considerando a extrapolação dos valores de três parâmetros fundamentais dos cálculos, custos de auditoria, preço da tonelada de carbono e fator de emissão. Estas variações são possíveis de ocorrer, conforme justificado no item 5.6, porém com um grau de probabilidade reduzido. 
A redução de $50 \%$ dos custos com as auditorias realizada na primeira análise, apresentou um resultado similar ao cenário de referência (item 5.5.1). A segunda simulação considerou o valor da tonelada de carbono de $€ 40,00$ (o cenário de referência utiliza $€ 19,20)$ e os indicadores financeiros evoluíram praticamente o dobro em relação ao cenário de referência.

A maior evolução nos indicadores financeiros, aproximadamente cinco vezes o cenário de referência, ocorreu quando realizada a terceira análise que elevou o fator de emissão para $1 \mathrm{tCO} / \mathrm{MWh}$ (o cenário de referência utiliza $0,279 \mathrm{tCO}_{2} / \mathrm{MWh}$ ). Nestas condições um projeto de eficiência energética que economize 10.000 MWh anualmente de energia elétrica, apresenta um aumento de $21,3 \%$ no VPL e uma evolução da TIR de 4 pontos percentuais. Esta evolução dos indicadores se apresenta atrativa, podendo viabilizar a realização do projeto de MDL, concomitantemente ao projeto de eficiência energética, exclusivamente pela evolução do desempenho financeiro do projeto.

De uma forma geral pode-se concluir que os projetos de eficiência energética de pequeno porte apresentam o seu desempenho financeiro reduzido com a inserção das despesas e receitas do projeto de MDL. Somente em projetos de maior porte os indicadores TIR e VPL apresentam um aumento em seu desempenho, entretanto, esta evolução é pequena podendo não compensar os riscos associados à execução do projeto de MDL (capítulo 6).

A busca pelo ganho de escala, realizando somente projetos de maior porte ou agrupando projetos com o intuito de obter uma economia de energia mais elevada, também não se apresenta como a questão que viabilizaria financeiramente o projeto de MDL, porque todos os gráficos da TIR apresentam uma saturação na evolução do seu desempenho em valores mais elevados de economia de energia elétrica.

Face ao exposto é possível concluir que nas condições de referência, que possuem a maior probabilidade de ocorrer, não é viável, sob o ponto de vista financeiro, realizar o processo para obtenção de créditos de carbono a partir de um projeto de eficiência energética, pois a inserção das despesas e receitas do projeto de MDL, sobre um projeto de eficiência energética de pequeno porte, reduz os indicadores TIR e VPL e no caso de projetos de grande porte ocorre o aumento destes indicadores, porém em uma escala pequena que possivelmente não compense os riscos associados à execução do projeto de MDL. 
Analisando sob o ponto de vista de uma instituição que não tem como objetivo principal realizar um projeto de MDL somente para aumentar os seus ganhos, mas que pretende associar a sua marca a um projeto sustentável, pode-se considerar que a realização do projeto de MDL, a partir de um projeto de eficiência energética é viável, porque além de atender o objetivo da sustentabilidade ainda promove um ganho adicional nos indicadores financeiros.

Considerando que venha a se concretizar as simulações de elevação do preço do crédito de carbono no mercado internacional ou de um projeto com elevado fator de emissão, que foram apresentados neste trabalho como de baixa probabilidade de ocorrer, é possível concluir que a inserção do projeto de MDL pode tornar o projeto de eficiência energética financeiramente viável. 


\section{REFERÊNCIA BIBLIOGRÁFICA}

ALVES, Sizenando Silveira. Tipificação dos instrumentos de políticas de apoio à eficiência energética: a experiência mundial e o cenário mundial. 2007. 184p. Dissertação (Mestrado) - Escola Politécnica, Universidade de São Paulo, São Paulo, 2007.

ANGELO, Cláudio. O aquecimento global. São Paulo, Publifolha, 2008

ARAUJO, Antonio Carlos Porto; Como Comercializar Créditos de Carbono; 5 Edição, 2007, São Paulo, Trevisan Editora Universitária.

BARDELIN, César Endrigo Alves. Os efeitos do racionamento de energia elétrica ocorrido no Brasil em 2001 e 2002 com ênfase no consumo de energia elétrica. 2004. 112p. Dissertação (Mestrado) - Escola Politécnica, Universidade de São Paulo, São Paulo, 2004.

BRASIL. Decreto 4.508 de 11 de dezembro de 2002. Dispõe sobre a regulamentação específica que define os níveis mínimos de eficiência energética de motores elétricos trifásicos de indução rotor gaiola de esquilo, de fabricação nacional ou importados, para comercialização ou uso no Brasil, e dá outras providências. Brasília, 2002.

BRASIL. Plano nacional sobre mudança do clima - PNMC. Brasilia, 2008

CARRIER. Catálogo técnico 23XRV: Chiller parafuso de alta eficiencia e velocidade variável - 300 a 550 Tons. [S.I.:s.n.]. [2007?].

CENTRAIS ELÉTRICA BRASILEIRAS, FUPAI/EFFICIENTIA. Eficiência energética em sistemas de refrigeração industrial e comercial. Rio de Janeiro, Eletrobrás, 2005.

CENTRO DE GESTÃO E ESTUDOS ESTRATÉGICOS. Manual de capacitação sobre mudança do clima e projetos de mecanismo de desenvolvimento limpo (MDL). Brasília. 2008

COMISSÃO DAS COMUNIDADES EUROPÉIAS. Livro verde sobre a eficiência energética. Bruxelas, 2005. 
CONSELHO EMPRESARIAL BRASILEIRO PARA O DESENVOLVIMENTO SUSTENTÁVEL; Roteiro Básico para Elaboração de um Projeto de Mecanismo de Desenvolvimento Limpo - MDL, Rio de Janeiro

EFFICIENCY VALUATION ORGANIZATION - EVO. Protocolo Internacional para Medição e Verificação de Performance. Tradução de Fernando de Castro Santos Milanez, Maria Helena Mendonça de Souza e Adriana Mesquita. Rio de Janeiro, INEE, 2001

ELETROBRÁS; FUPAI/Escola Federal de Itajubá - EFEl. Conservação de Energia: Eficiência energética de instalações e equipamentos. Itajubá, Editora da EFEI, 2001.

ELETROBRÁS; FUPAI/EFFICIENTIA. Gestão energética. Rio de Janeiro. [s.n.]. 2005.

ELETROBRÁS; Universidade Federal de Itajubá - UNIFEI; FUPAI. Eficiência

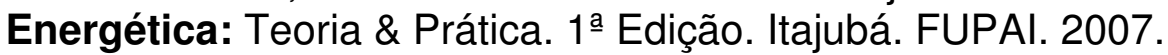

EMPRESA DE PESQUISA ENERGÉTICA - EPE. Plano Decenal de Expansão de Energia Elétrica 2006-2015. Brasília, MME, EPE, 2006a.

EMPRESA DE PESQUISA ENERGÉTICA - EPE. Balanço Energético Nacional 2007 ano base 2006. Brasília, MME, EPE, 2006b.

FREIRE, Luciano Macedo. Balanço de Leilões de Energia Elétrica no Brasil. In Encontro de Negócios de Energia, 9, 2008, São Paulo. Apresentação. São Paulo, 2008.

FUNDAÇÃO GETÚLIO VARGAS; O Mecanismo de Desenvolvimento Limpo MDL: Guia de Orientação; Rio de Janeiro, FGV Editora, 2002.

GARCIA, Agenor Gomes Pinto. Leilão de Eficiência Energética no Brasil. Rio de Janeiro, 2008. Tese (Doutor em Ciência em Planejamento Energético), Universidade Federal do Rio de Janeiro

GELLER, Howard; SCHAEFFER, Roberto; SZKLO, Alexandre; TOLMASQUIM, Maurício. Policies for advancing energy efficiency and renewable energy use in Brazil. Energy policy, Estados Unidos, Elsevier, 2004. n. 32, p. 1.437-1.450. 
GITMAN, Lowrence J. Princípios de Administração Financeira Essencial. $2^{\underline{a}}$ Ed. Tradução de Jorge Riter. Porto Alegre, Bookman Editora, 2001.

GOLDEMBERG, Jose; VILLANUEVA, Luz Dondero. Energia, Meio Ambiente \& Desenvolvimento. 2 ${ }^{a}$ Edição. São Paulo, Editora da Universidade de São Paulo Edusp, 2003.

GRAU, Werner Neto. O protocolo de quioto e o mecanismo de desenvolvimento limpo - MDL: uma análise crítica do instituto. São Paulo, Editora Fiúza, 2007

GREENPEACE. Revolução Energética: Perspectivas para uma energia global sustentável. [S.I.:S.n.] 2007

GRIMONI, José Aquiles Baesso; GALVÃO, Luiz Cláudio Ribeiro; UDAETA, Miguel Edgar Morales (Organizadores). Iniciação a conceitos de sistemas energéticos para o desenvolvimento limpo. São Paulo, Editora da Universidade de São Paulo Edusp, 2004.

HADDAD, Jamil; AGUIAR, Sérgio Catão (Coordenadores). Eficiência Energética: Integrando usos e reduzindo desperdícios. Brasília: Aneel, 1999.

INHABER, Herbert. Why Energy Conservation Fails. Westport, Quorum Books, 1997

INSTITUTO ASCENDE BRASIL. Programa Energia Transparente. 4⿳亠丷a Edição. [S.I.:S.n.] 2008

JANNUZZI, Gilberto de Martino; KOZLOFF, Keith; MIELNIK, Otávio; COWART, Richard. ENERGIA: Recomendações para uma estratégia nacional de combate ao desperdício. Campinas. Grafcamp Editora e Gráfica Ltda. 2001a.

JANNUZZI, Gilberto de Martino. Aumentando a eficiência nos usos finais de energia no Brasil. Campinas, UNICAMP, 2001 ?b.

JANNUZZI, Gilberto de Martino; DANELLA, Marcos Antonio; SILVA, Silvio A. Scucuglia. Metodologia para avaliação da aplicação dos recursos dos programas de eficiência energética. Campinas, Energy Discussion Paper, 2004. 
JANUZZI, Gilberto de Martino; HADDAD, Jamil; SAIDEL, Marco Antonio; POOLE, Alan. Regulamentação dos projetos de EE das concessionárias de distribuição de eletricidade: sugestão para uma revisão. Apresentação, 2007, [S.I.].

KEELLING, Ralph. Gestão de Projetos: Uma abordagem global. Tradução de Cid Knipel Moreira. Revisão Técnica de Orlando Cattini Junior. São Paulo: Editora Saraiva, 2006

LAMBERTS, Roberto; TRIANA, Maria Andréa. Levantamento do estado da arte: Energia. São Paulo, [s. n.], 2007.

MINISTÉRIO DA CIÊNCIA E TECNOLOGIA - MCT. Status atual das atividades de projeto no âmbito do Mecanismo de Desenvolvimento Limpo (MDL) no Brasil e no mundo: 30 de setembro de 2008. Brasília, 2008a.

MINISTÉRIO DA CIÊNCIA E TECNOLOGIA - MCT. Fatores de Emissão de $\mathrm{CO}_{2}$ pela geração de energia elétrica no Sistema Interligado Nacional do Brasil. 2008b. Disponível em http://www.mct.gov.br. Acesso em 01 nov. 2008.

MINISTÉRIO DE MINAS E ENERGIA - MME. Matriz Energética Nacional 2023. Brasília, MME, 2005

MINISTÉRIO DE MINAS E ENERGIA - MME. Plano Nacional de Energia 2030: Eficiência Energética 2006-2007. Brasília, MME, 2007a

MINISTÉRIO DE MINAS E ENERGIA - MME. Planejamento Energético Nacional. In Congresso Brasileiro de Eficiência Energética e Cogeração de Energia, 4, 2007, São Paulo. Apresentação. São Paulo, 2007b.

MORALES, Flávia. Philips aposta R\$2,6bi em eficiência energética até 2012. [Entrevista a Paula Graciela para a Revista Sustentabilidade], Maio de 2008.

NETO, Raymundo Moniz de Aragão. Gerenciamento de riscos em projetos de eficiência energética. 2003. 34p. Monografia (MBA em Gerência de Projetos) Fundação Getúlio Vargas, Rio de Janeiro, 2003

OSRAM. Iluminação: Conceitos e Projetos. [S.I.:s.n.], [200-?] 
PRADO, Fernando Amaral de Almeida Junior. Diretrizes orientativas para concepção de projetos de eficiência energética. [S.I.], ESMAP, 2007.

PROCEL. Resultados do PROCEL 2006. Rio de Janeiro, 2007

RAAD, Antonio; SCHECHTMAN, Rafael. Identificação das barreiras ao uso eficiente da energia elétrica. In: CONGRESSO BRASILEIRO DE ENERGIA, 7., 1996, Rio de Janeiro. Anais. Rio de janeiro: Artimagem, 1996. p. 2.051-2.058

RIBEIRO, Zenilda Barbosa; Parâmetros para análise de projetos de eficiência energética em eletricidade, São Paulo, 2005, Dissertação (Mestre em Energia), Instituto de Eletrotécnica e Energia da Universidade de São Paulo

ROCHA, Marcelo Theoto; Aquecimento global e o mercado de carbono: Uma aplicação do modelo CERT, Piracicaba, 2003 Tese (Doutor em Agronomia), Escola Superior de Agricultura "Luiz de Queiroz" da Universidade de São Paulo

ROSA, Luiz Pinguelli. Eficiência energética é a forma mais barata de reduzir consumo de energia e conter mudanças climáticas. [Entrevista a Carolina Medeiros para o PROCEL Info], Janeiro de 2008.

SOUZA, Rafael Pereira de (Coordenador). Aquecimento Global e Créditos de Carbono: Aspectos Jurídicos e Técnicos. São Paulo, Quartier Latin, 2007.

SEBRAE/RJ, GTZ. Avaliação dos impactos econômicos-financeiros de projetos de eficiência energética em indústrias de pequeno porte. $1^{\underline{a}}$ Edição. Rio de Janeiro. York Indústrias Gráficas. 2003. (Cooperação bilateral entre os governos do Brasil e da Alemanha).

SISTER, Gabriel. Mercado de Carbono e Protocolo de Quioto. Rio de Janeiro, Elsevier, 2007

TAYLOR, Robert P. et al. Financing Energy Efficiency: Lessons from Brazil, China, India and Beyond. Washington DC: Banco Mundial, 2008.

TOLMASQUIM, Maurício Tiomno (Coordenador). Metodologias de valoração de danos ambientais causados pelo setor elétrico. Rio de Janeiro: UFRJ, 2000. 
TREMBLAY, Alain; VARFALVY, Louis; ROEHM, Charlotte; GARNEAU, Michelle. The issue of greenhouse gases from hydroelectric reservoirs: from boreal to tropical regions. Québec, University of Québec in Montreal, 2005?

UNITED NATIONS. Protocolo de Quioto. Tradução de Ministério da Ciência e Tecnologia. Brasília, [s.n.], [1998?],

ZACHAR, Sy. Energy Efficiency and Budgetary Improvement. In: ENERGY TECHNOLOGY CONFERENCE, 11., 1984, Washington. Anais. Maryland: Government Institutes, Inc, 1984. p. 261-270. 


\section{ANEXO A - Fórmulas da modelagem da análise de viabilidade}

A modelagem apresentada possui três quadros iniciais, conforme títulos abaixo, onde são trabalhados os dados básicos para serem inseridos no fluxo de caixa.

\section{- DADOS DO PROJETO}

- PREMISSAS

- ECONOMIA DE ENERGIA

No quadro "DADOS DO PROJETO" devem ser inseridas as três informações principais do projeto de eficiência energética: investimento total (sem considerar os gastos com o projeto de MDL), redução de demanda e economia anual de energia.

\begin{tabular}{lr}
\hline \multicolumn{2}{c}{ DADOS DO PROJETO } \\
\hline Investimento & $\mathrm{R} \$ 681.700,00$ \\
\hline Redução demanda (kW) & 213,0 \\
\hline Economia anual de energia (MWh) & $1.000,0$ \\
\hline
\end{tabular}

Para realizar todos os cálculos necessários na modelagem o quadro "PREMISSAS" contém os parâmetros de variáveis que são considerados. Neste quadro os valores podem ser alterados criando vários cenários de um determinado projeto.

\begin{tabular}{|c|c|}
\hline \multicolumn{2}{|l|}{ PREMISSAS } \\
\hline Tarifa de energia na ponta úmida ( $\mathrm{R} \$ / \mathrm{MWh})$ & 208,02 \\
\hline Tarifa de energia na ponta seca ( $\mathrm{R} \$ / \mathrm{MWh})$ & 230,16 \\
\hline Tarifa de energia fora de ponta úmida ( $R \$ / M W h)$ & 130,14 \\
\hline Tarifa de energia fora de ponta seca ( $\mathrm{R} \$ / \mathrm{MWh})$ & 142,98 \\
\hline Tarifa de demanda na ponta $(\mathrm{R} \$ / \mathrm{kW})$ & 32,73 \\
\hline Tarifa de demanda fora de ponta $(\mathrm{R} \$ / \mathrm{kW})$ & 8,07 \\
\hline Conversão de $€$ em $\mathrm{R} \$$ & 2,5 \\
\hline Fator de emissão em $\mathrm{tCO}_{2} / \mathrm{MWh}$ & 0,279 \\
\hline Alíquota do PIS + Cofins & $9,25 \%$ \\
\hline Preço do crédito em $€$ & 19,2 \\
\hline Custo da auditoria de implantação s/ ativo & $\mathrm{R} \$ 90.000,00$ \\
\hline Ativos instalados para verificação & $\mathrm{R} \$ 20.000,00$ \\
\hline Custo da auditoria de verificação & $\mathrm{R} \$ 10.000,00$ \\
\hline Taxa de desconto & $13,75 \%$ \\
\hline Alíquota do Imposto de Renda & $34 \%$ \\
\hline Taxa anual de crescimento & $8 \%$ \\
\hline
\end{tabular}


Todos os valores deste quadro são inseridos manualmente onde os valores de (d) a (i) correspondem à tarifa de energia da instalação analisada, que depende da distribuidora de energia, da tensão de conexão à rede e da modalidade tarifária escolhida.

No último quadro da modelagem é realizado o cálculo do valor financeiro correspondente à energia que foi economizada com o projeto.

\begin{tabular}{|c|c|}
\hline ECONOMIA DE ENEI & \multirow[b]{2}{*}{10,4} \\
\hline Economia ponta (MWh) & \\
\hline Economia fora de ponta (MWh) & 72,9 \\
\hline Redução de demanda ponta (kW) & 213,0 \\
\hline Economia de energia ponta $(\mathrm{R} \$)$ & $2.301,41$ \\
\hline Economia de energia fora de ponta $(\mathrm{R} \$)$ & $10.035,52$ \\
\hline Redução de demanda ponta ( $R \$)$ & $6.972,51$ \\
\hline Redução de demanda fora de ponta ( $\mathrm{R} \$$ ) & $1.719,16$ \\
\hline Total mensal sem impostos ( $\mathrm{R} \$$ ) & $21.028,60$ \\
\hline Total anual com Impostos $(\mathrm{R} \$)$ & $332.030,56$ \\
\hline
\end{tabular}

Os três primeiros campos correspondem à cópia dos valores do primeiro quadro sendo que a economia de energia anual é transformada em mensal e dividida entre os horários de ponta e fora de ponta da seguinte forma:

$(\mathrm{t})=(\mathrm{c} / 12) / 24^{*} 3$

$(\mathrm{u})=(\mathrm{c} / 12)-\mathrm{t}$

A redução de demanda na ponta $(v)$ corresponde exatamente à cópia do campo (b) do primeiro quadro.

Os campos (w) a (z) executam o cálculo do valor financeiro de energia e demanda de ponta e fora de ponta que foi economizada com o projeto:
$(w)=\left(\left(\left(e^{*} 7\right)+\left(d^{\star} 5\right)\right) / 12\right)^{*} t$
$(\mathrm{x})=\left(\left(\left(\mathrm{g}^{\star} 7\right)+\left(\mathrm{f}^{\star} 5\right)\right) / 12\right)^{*} \mathrm{u}$
$(y)=v^{*} h$
$(\mathrm{z})=\mathrm{v}^{*} \mathrm{i}$

Os campos $\alpha$ e $\beta$ totalizam o valor financeiro correspondente à economia de energia da seguinte forma:
$(\alpha)=w+x+y+z$
$(\beta)=(\alpha /(1-18 \%-6 \%))^{*} 12$ 
O campo a soma os valores financeiros de energia e demanda e o campo $\beta$ acresce os impostos ICMS, PIS e Cofins além de transformar o valor mensal de a em um valor anual multiplicando por 12 .

A alíquota de ICMS considerada é de $18 \%$ e a alíquota de PIS + Cofins adotada é de $6 \%$. Neste cálculo o valor do imposto compõe à base de cálculo, conhecido como método "por dentro".

Depois de realizado os cálculos preliminares, a modelagem utiliza duas planilhas, a primeira representada o projeto de eficiência energética isoladamente, na qual a única despesa é o investimento inicial do projeto, e a receita considerada é a economia de energia durante os dez anos do horizonte analisado.

A segunda planilha reflete o fluxo de caixa estabelecido no item 5.3.2 na qual as despesas consideradas são: investimento do projeto de eficiência energética, a auditoria de implantação e as auditorias anuais de verificação. As receitas consideradas são: economia de energia e a vendas das RCEs. 


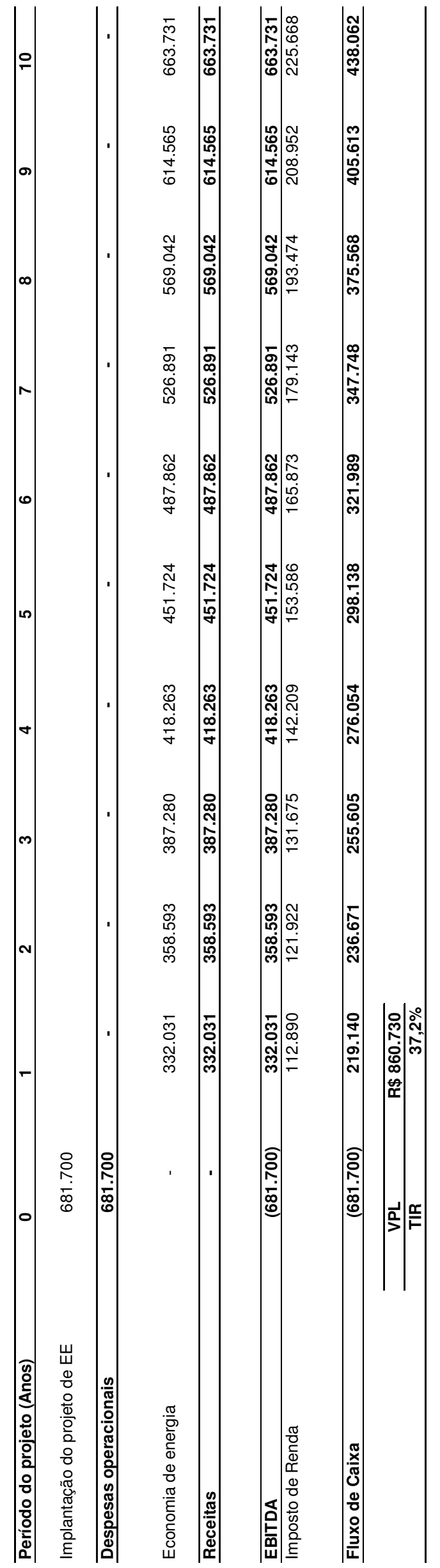


A tabela anterior utiliza um horizonte de dez anos de contabilização do projeto de MDL mais o ano zero de implantação do projeto de eficiência energética.

Somente o dispêndio com a implantação do projeto é contabilizada como despesa e este valor é extraído da célula (a) e inserido no ano zero. A única receita contabilizada é a economia de energia que é copiada da célula $(\beta)$ e inserida na linha de economia de energia no primeiro ano do projeto, as demais economias de energia dos próximos nove anos acrescem a taxa de crescimento (s) anualmente em relação ao valor do primeiro ano. O Ebitda calcula a diferença entre as despesas e receitas, ou seja é o lucro antes dos juros, impostos, depreciação e amortização.

Apesar de que os ativos instalados no projeto de eficiência energética (luminárias, motores, chillers) poderiam ser caracterizados como bens depreciáveis, esta modelagem não os considera por dois motivos, primeiro porque como está sendo realizada uma substituição, a depreciação já deveria estar sendo considerada no balanço da empresa e este projeto não está inserindo nenhum ativo novo que alteraria a contabilidade já existente. Em segundo lugar o objetivo deste trabalho é avaliar o mesmo projeto de eficiência energética com e sem crédito de carbono, portanto, a depreciação destes ativos contribuiria igualmente para as duas situações (projeto com créditos de carbono e projeto sem créditos de carbono), sendo assim eles não influenciam no objetivo da análise.

A linha do Ebit retira a depreciação do Ebitida, ou seja o Ebit também pode ser chamado do lucro antes de juros e do imposto de renda, que nesta tabela não sofre nenhuma influência e sobre esta linha é aplicado o imposto de renda, sendo que a subtração entre o Ebitida e o imposto de renda corresponde ao fluxo de caixa do projeto e sobre esta linha é calculado o VPL e a TIR.

Estes valores representam o desempenho financeiro do projeto de eficiência energética considerando que ele será realizado independente de qualquer busca por créditos de carbono. Nesta análise as receitas consideradas foram simplesmente a economia de energia e a única despesa o preço do investimento para realizar o projeto de eficiência energética.

A próxima tabela representa o mesmo projeto com a inserção das despesas necessárias para realização do projeto de MDL e as receitas advindas da venda dos créditos de carbono. 


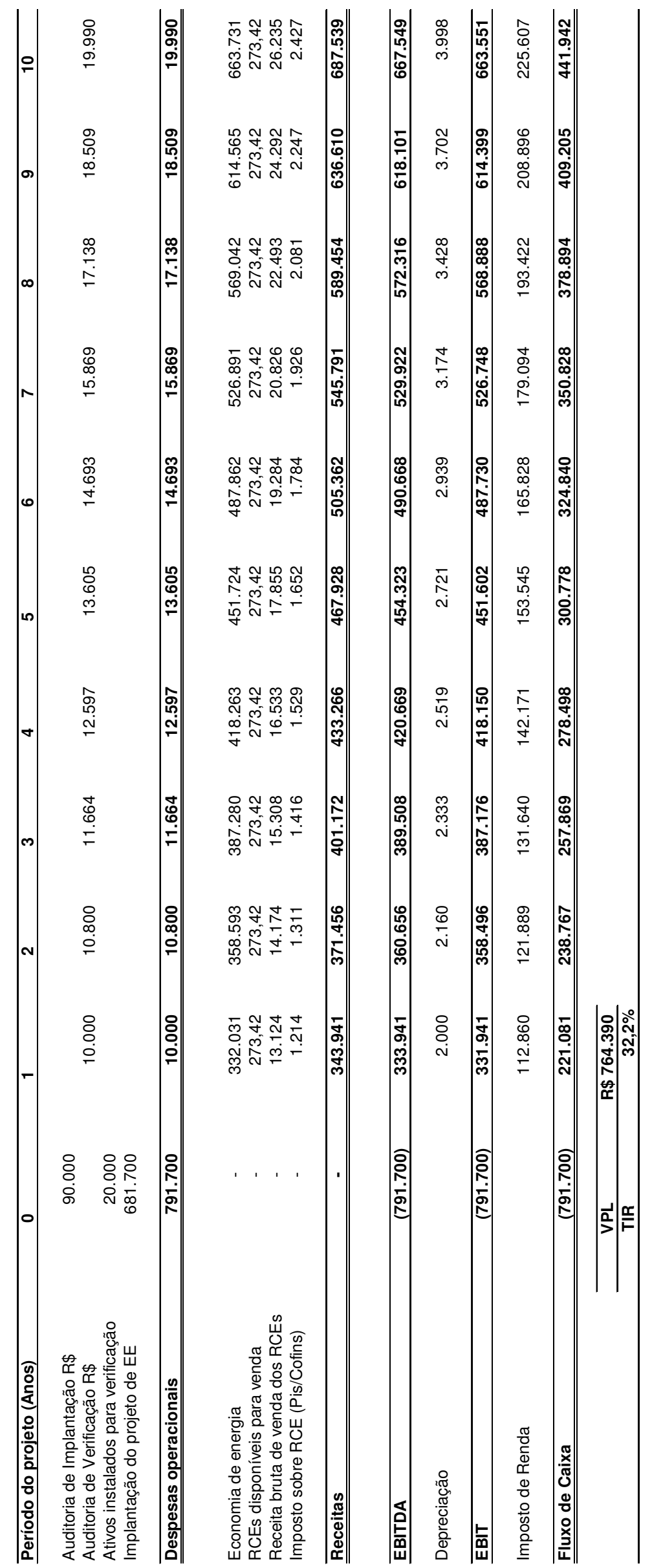


A tabela anterior também utiliza um horizonte de dez anos de contabilização do projeto de MDL mais o ano zero de Implantação do projeto de eficiência energética, para que seja possível comparar as duas situações, a partir dos mesmos parâmetros de análise.

Neste caso além do dispêndio com a implantação do projeto extraído da célula (a), o ano zero conta também com a despesa do preço da auditoria de implantação constante na célula (n) e a despesa do preço de ativos instalados para verificação, extraídos da célula (o), que basicamente são medidores que serão utilizados para conferir as efetivas reduções no consumo de energia que são a base da redução de emissões dos GEE.

A contabilização das receitas da tabela é composta de quatro linhas sendo que a primeira representa a economia de energia, que se apresenta da mesma forma que explicada na tabela anterior, a segunda linha representa as RCEs que o projeto disponibiliza para venda, para se obter este valor deve-se multiplicar a energia economizada, célula (c), pelo fator de emissão, célula (k), e deste valor é excluído $2 \%$ que é a taxa da UNFCCC, sendo que a fórmula desta linha do projeto fica da seguinte forma:

RCEs disponíveis para venda $=\mathrm{C}^{*} \mathrm{k}^{*} 0,98$

Este item não possui correção anual uma vez que o fator de emissão adotado para o projeto deve ser mantido durante o seu período de realização, a energia economizada deve ser a mesma durante o período e a taxa de $2 \%$ é constante. A terceira linha converte a quantidade de RCE em valor financeiro, multiplicando 0 valor da segunda linha pelo valor do crédito em $€$ e pelo fator de conversão de $€$ em $\mathrm{R} \$$, sendo que a sua fórmula fica da seguinte forma:

Receita bruta de venda das RCEs = "RCEs disponíveis para venda"* $\mathrm{m}^{*} \mathrm{j}$

Como o valor do crédito é passível de alteração, a modelagem considera o seu crescimento a taxa definida na célula (s) a partir do segundo ano. $O$ valor do crédito é definido no livre mercado obtido através de leilões, por este motivo é difícil a realização de estimativas de valores futuros e esta análise definiu a utilização da taxa anual de crescimento comum para os demais índices. 
A última linha que compõe o grupo das receitas é o imposto aplicado sobre a venda das RCEs. Foi considerada uma alíquota de 1,65\% para o PIS e 7,6\% para o Cofins, perfazendo um total de $9,25 \%$ que é o valor utilizado na modelagem, sem nenhuma redução na base de cálculo.

Por fim a linha "Receitas" da modelagem soma o valor financeiro da economia de energia com o valor da venda das RCEs e subtrai os impostos aplicado sobre esta venda ficando com a seguinte fórmula:

Receitas = "Economia de energia" + "Receita bruta de venda dos RCEs" - "Imposto sobre RCE (PIS/Cofins)"

O Ebitida simplesmente calcula a diferença entre as despesas e receitas e em seguida é aplicada a depreciação dos ativos de medição instalados durante a fase de implantação do projeto de eficiência energética e que durante as auditorias de verificação serão utilizados para conferir a real redução no consumo de energia. Foi considerado que os equipamentos de medição possuem uma vida útil de dez anos, portanto a taxa de depreciação utilizada é de $10 \%$ ao ano sobre a célula (o) com correções a partir do segundo ano com a taxa da célula (s).

A linha do Ebit retira a depreciação do Ebitida e sobre esta linha é aplicado o imposto de renda da célula ( $r$ ), sendo a subtração entre o Ebitida e o imposto de renda o fluxo de caixa do projeto e sobre esta linha é calculado o VPL e a TIR.

Comparando o VPL e a TIR da primeira tabela com os mesmos valores da segunda tabela é possível avaliar a influência da inserção das despesas e receitas do projeto de MDL sobre o desempenho financeiro de um projeto de eficiência energética. 